


\section{DREAM WORLDS Modern Japanese Prints \\ FROM THE ROBERT O. MULLER COLLECTION}



Calouste Gulbenkian Museum

\section{Modern Japanese Prints \\ FROM THE ROBERT O. MULLER COLLECTION}

Temporary Exhibition Gallery

26 October 2006 - 7 January 2007

CALOUSTE

GULBENKIAN

FOUNDATION 
GENERAL COORDINATION João Castel-Branco Pereira Nuno Vassallo e Silva

\section{Exhibition}

CURATOR

James T. Ulak

\section{EXECUTIVE COORDINATION \\ Maria Queiroz Ribeiro \\ with the assistance of Carla Paulino}

\section{EXHIBITION DESIGN AND SET-UP COORDINATION}

Mariano Piçarra

with the assistance of Ricardo Viegas

\section{GRAPHIC DESIGN}

TVM Designers - Luís Moreira

\section{SET-UP AND INSTALLATION}

Museography section, Calouste Gulbenkian Museum

Maria Antonieta Amorim and Miguel Fumega

with the assistance of António Figueiredo and Rui Nunes

Rui Xavier

SET-UP A ND LIGHTING

Construções Martins Sampaio, Ld. ${ }^{a}$

Central Department, Calouste Gulbenkian Foundation

\section{PUBLICITY}

Communication Department,

Calouste Gulbenkian Foundation

Calouste Gulbenkian Museum:

Alexandra Lopes de Almeida

\section{EDUCATION}

Guided Visits

For organised groups contact:

Isabel Oliveira e Silva

isilva@gulbenkian.pt

Maria do Rosário Azevedo

mrazevedo@gulbenkian.pt

Tel.: $217823455 / 6$

Fax: 217823032

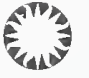

Smithsonian

Arthur M. Sackler Gallery

This exhibition has been produced in collaboration with Arthur M. Sackler Gallery, Smithsonian Institution, Washington, D.C.

\section{Catalogue}

EDITORIAL COORDINATION

João Carvalho Dias

with the assistance of Carla Paulino

and Madalena Martins

TEXTS

James T. Ulak

\section{GRAPHIC DESIGN AND COORDINATION}

TVM Designers - Luís Moreira

\section{PHOTOGRAPHY}

(c) Arthur M. Sackler Gallery, Smithsonian Institution,

Washington, D.C.

\section{PRINTING AND FINISHING}

Cromotipo, Artes Gráficas

COVER: Hashiguchi Goyỏ (1880-1921), Woman combing her hair, Japan, 1920 (cat. no. 37)

(c) Arthur M. Sackler Gallery, Smithsonian Institution,

Washington, D.C.

www.museu.gulbenkian.pt

www.gulbenkian.pt

(ㄷ) Calouste Gulbenkian Foundation, Lisbon

English edition 500 copies, October 2006

Portuguese edition 1000 copies, October 2006

ISBN 10: 972-8848-25-0 / 13: 978-972-8848-25-5 English edition ISBN 10: 972-8848-24-2 / 13: 978-972-8848-24-8 Portuguese edition

Legal depot: 248878/06

\section{CHRONOLOGY}

Periods (1600 - present)

$\begin{array}{ll}\text { Edo or Tokugawa } & 1600-1868 \\ \text { Meijo } & 1868-1912 \\ \text { Taishô } & 1912-1926 \\ \text { Shôwa } & 1926-1989 \\ \text { Heisei } & 1989 \text {-present }\end{array}$


In An ACt of great generosity, the Arthur M. Sackler Gallery, Smithsonian Institution, Washington, D.C., decided to join the celebrations of the fiftieth anniversary of the Calouste Gulbenkian Foundation by offering the Dream Worlds exhibition, an exceptional selection of modern Japanese prints from the Robert O. Muller Collection.

Robert O. Muller (1911-2003) was an art dealer and enthusiastic collector who assembled what is probably the world's greatest collection of Japanese Shin-hanga, or new prints. Muller not only had the financial capacity to pursue his interests as a collector, but also - like Calouste Gulbenkian - his acquisitions were guided by his personal taste, often going against the dominant trends of the age.

Dream Worlds offers the Portuguese public the chance to discover this outstanding form of artistic expression, one that has a long tradition in Japanese culture. Such prints could circulate easily, and when Japan opened up to the outside world, examples from the classical period reached Europe. They circulated widely, especially during the second half of the nineteenth century, attracted the attention of collectors and held a special fascination for the Impressionists. Although modern Japanese prints were open to external influences, particularly from the West, they remained true to the fine techniques developed in the past and preserved many of the themes and the forms of depicting them.

This provides the context for the extra-catalogue exhibition of some prints from the Calouste Gulbenkian Collection that are normally kept in the storerooms. Direct comparison between these earlier works (dating from the eighteenth and nineteenth centuries) and the twentieth-century pieces from the Robert O. Muller Collection confirms that the tradition was revived by the Shin-hanga artists.

The exhibition from Washington has been curated by James T. Ulak, deputy director of the Arthur M. Sackler Gallery, who is also responsible for the catalogue texts. This event is of even greater significance as it is the result of the excellent relations between the Calouste Gulbenkian Foundation and the Smithsonian Institution in recent years, signalling the successful implementation of different cultural projects that fundamentally aim at a deeper understanding of themes related to cultural diversity.

EMÍlio Rui Vilar

President of the Calouste Gulbenkian Foundation 

It is A NATURAL ACT OF COURTESY to send gifts to celebrate an anniversary.

The Arthur M. Sackler Gallery (Washington, D.C.) decided that in this case - the fiftieth anniversary of the Calouste Gulbenkian Foundation - a fitting birthday gift would be a surprising exhibition of Japanese prints, selected from among the vast collection assembled by Robert O. Muller and incorporated into the Gallery at the collector's express wish.

Japanese prints are always technically sophisticated works. Using an almost ritualistic method, they have subtly cultivated an implicit wisdom over the centuries, and the resulting works have developed themes and systems of perceiving reality that make them unique and unmistakeable in the world of art.

This art-form has such a clearly defined identity that it may lead the viewer to establish a stereotyped idea of the work, the result both of its recurrent themes and the recurrent ways of expressing them.

The European taste for collecting Japanese pieces, in which prints hold centre stage, is well known. Suffice it to recall the 1868 portrait of Emile Zola by Edouard Manet, which features a decoration comprising Japanese objects, including a Ukiyo-e print. This same motif completely covers the background of the portrait of Père Tanguy by Vincent Van Gogh, from 1887-1888.

The section of eighteenth- and nineteenth-century Japanese print that Calouste Gulbenkian assembled follows the model established in collecting, while some of the pieces are out-of-catalogue, further reinforcing the relevance of this exhibition within the Museum's overall programme.

Yet Japanese prints did not just establish their position in nineteenth-century European culture as collectors' items. Rather, their impact came essentially through Western art's assimilation of their qualities, which transformed its values of composition and visual synthesis, in turn influencing the work of such fundamental artists as Vincent Van Gogh, Paul Gauguin, Henri Toulouse-Lautrec and Edouard Vuillard. The paintings of James Whistler, which not only use Japanese motifs but the Japanese vision, and even more particularly the graphic work of Mary Cassatt offer clear examples of this influence.

"Dream Worlds" reveals the historical period that came after these Japanese prints, which were simultaneously sought after by sophisticated collectors and acted as a revivalist inspiration for nineteenth-century art.

The exhibition also shows how this tradition was renewed in twentieth-century Japan as technical procedures were maintained and as artists adopted increasingly indi- 
vidualistic stances, moving closer to the values of modern European culture. Not only did they update their iconographies, but also emphasised a deliberately abstract quality when creating their images.

This explains why this was such a wonderful present, one that portrays the twentieth century through an ancient yet recreated tradition. The gift came thanks to the dedication of Julian Raby, director of the Arthur M. Sackler Gallery and Freer Gallery of Art, and his deputy director, James T. Ulak, who curated the exhibition. I would like to thank them both for their kindness and for the rigor used in preparing this project.

Special words of gratitude are due to the Museum staff, who were vital for the successful organisation and production of the exhibition and the catalogue. Thus, my thanks go to curator Maria Queiroz Ribeiro for her executive coordination of the exhibition, to João Carvalho Dias for coordinating the catalogue, and to Mariano Piçarra for the exhibition design. I would also like to thank Carla Paulino, Madalena Martins and Ricardo Viegas, and the entire Museum staff for their support in the respective areas.

João Castel-Branco Pereira

Director of the Calouste Gulbenkian Museum 
Robert O. Muller died in April 2003 and bequeathed his collection of nearly 4,500 late nineteenth- and early twentieth-century Japanese prints, paintings and related archival materials - arguably the finest collection of its kind in the world - to the Arthur M. Sackler Gallery, Smithsonian Institution. The Sackler Gallery and neighboring Freer Gallery of Art together form the national museums of Asian art for the United States.

This gift came to us as a complete surprise, but one of the reasons Robert O. Muller chose the Sackler Gallery as the permanent home for his collection is that he appreciated the Sackler Gallery's ability to make loans of his prints to other institutions around the world. We are delighted, then, to offer "Dream Worlds" - a selection of masterworks from Muller's extensive holdings - to the audiences of the Gulbenkian Museum in Lisbon. During the past several years there has been a notable increase in the pace of scholarly and programmatic collaboration between our two institutions. This is due in no small part to a mutual realization of a common lineage: descent from founders who were passionate collectors dedicated to ideals of beauty and scholarship, indeed to the scholarship required to explicate the many meanings of beauty in diverse cultures.

The best collecting seems to be a solitary and stubborn activity, paying heed to finely honed instincts that often run counter to majority opinions or trends. Calouste Gulbenkian, Charles Lang Freer and Arthur M. Sackler certainly shared these traits, but they also shared a profound sense of social purpose. Their contributions to the larger community were not simply gifts of accumulated things, but distinctly individual visions of how those things could form a meaningful mosaic.

Robert Muller spent many of his collecting years at a determined and intentional distance from the fashionable ideas and trends in Japanese art collecting. Now Muller's persistence and prescience provide us with material vital to the understanding of visual culture as it developed during Japan's most turbulent century.

"Dream Worlds", originally presented at the Arthur M. Sackler Gallery in 2004 as the induction of a distinguished collector's insights into the public domain, seems a thoroughly fitting way to celebrate the important fiftieth anniversary year marking Calouste Gulbenkian's own remarkable generosity. We hope that audiences in Lisbon will be charmed by the fragile world captured by Mr. Muller's collection, and inspired by his passionate vision.

JUL1AN RabY

Director, Arthur M. Sackler Gallery and Freer Gallery of Art,Smithsonian Institution 



\section{Contents}

Robert $\mathrm{O}$. Muller and his collection

Joan B. Mirviss and James T. Ulak

The Catalogue of Prints

James T. Ulak

Stage Presence

Beauty Personified

60

The Quality of Light

82

Creatures Real and Imagined

99

Biographies

105 Glossary

107

Bibliography

109

Index 


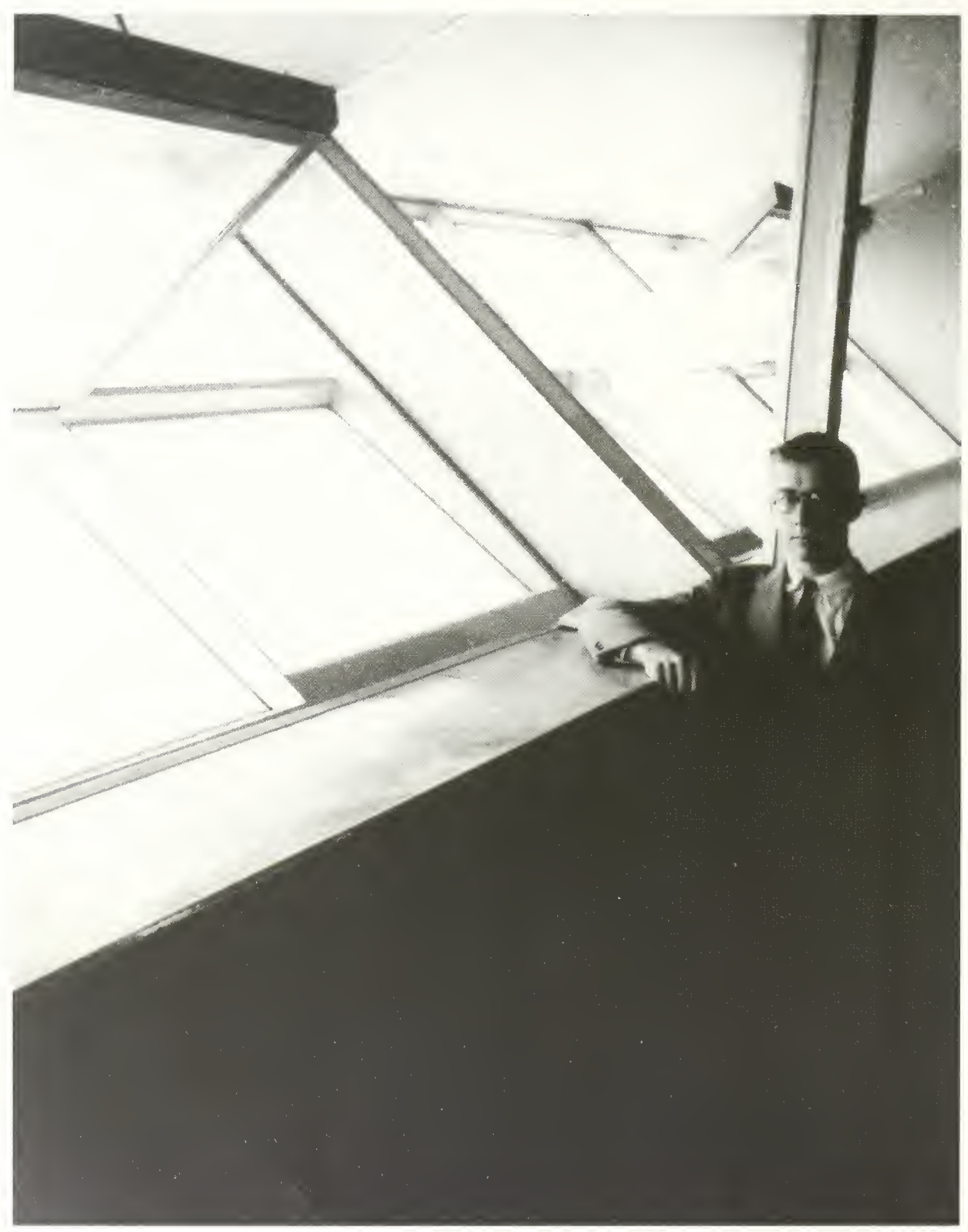




\section{Robert O. Muller and his collection*}

Not many collectors have had the tenacity, perseverance and genetic good fortune to collect in a defined area for more than seventy years. Robert Otto Muller (1911-2003) was one of those few making acquisitions almost until his death at the age of 91 on April 10, 2003. His prescient collecting in a largely overlooked area of Japanese prints ultimately created a stunning aesthetic and intellectual archive which is now only beginning to be mined for the insights it offers into the trajectory of Japanese art from the $19^{\text {th }}$ century into the modern era.

First exposed to Japanese prints in his teen years, Muller made his initial acquisition (a night scene of a bridge by the landscape print designer Kawase Hasui) in 1931 as a 20-year old student at Harvard University. He was instantly smitten when he saw this print in a New York shop window and it became the first purchase of many thousands over the decades. Notably, the print was not a traditional $18^{\text {th }}$ or $19^{\text {th }}$ century print $-\mathrm{a}$ type with which many Westerners were already familiar - but a work that was virtually contemporary. Shortly before his death, Muller wrote: "Once bitten by the Modern Print bug it is incurable, as I can attest from personal experience. And the more you see, the wider the field becomes."

This remarkable collector was born in Pelham, New York on 5 October 1911, the second of three children. At the age of six, after his mother, Gertrude Erbsloh, divorced from his German-born father Robert Otto Muller, the young Muller and his elder brother Erhart were sent off to a series of boarding schools. The emotional trauma of that period was somewhat balanced by an apparent level of social and economic comfort provided by the fact that Muller's maternal great-grandfather, Charles Erhart, was a founder of the Brooklyn, New York-based pharmaceutical company, Pfzier. Happier summer holidays were typically spent both at seaside family homes and also with cousins in Germany. Muller became fluent in German and developed a life-long interest in the German language and culture, especially opera. Two years after graduating from Harvard in 1934, through connections at his temporary job with Lufthansa Airlines, Muller was able to fly to Frankfurt on the infamous Hindenburg for the then princely sum of \$400 one way. An instinctive archivist, he kept all of the documents and souvenirs related to that memorable voyage. During his return to the States by way of England, he visited Thomas Bates Blow (1854-1941), a prominent botanist and Japanese print enthusiast. It was Blow who introduced Muller to the world of Meiji era prints, most prominently works by Kobayashi Kiyochika (1847-1915), whose unique vision of early Meiji Japan captivated him.

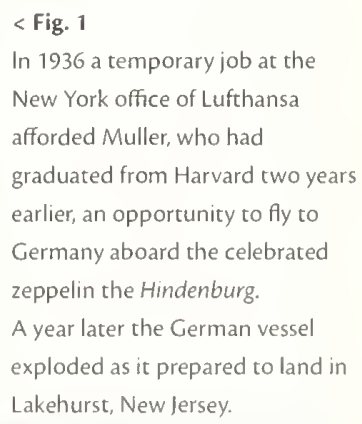


Fig. 2

Robert Muller and his bride, Inge, at the Imperial Hotel, Tokyo, in 1940, admiring the first print designed by Natori Shunsen - Nakamura Ganjirō as Kamiya Jihei (1916). The couple had just purchased the print from Watanabe Shōzaburō for seven dollars.

Photograph first published in the Japan Times and Mall, April 19, 1940, from the Robert O. Multer Papers, Freer Galtery of Art and Arthur M. Sackler Callery Archives, Smithsoman Institution, Washington, D C
Thus, within a relatively short period of time during the mid-193os Muller sensed an intense affinity for large amounts of Japanese print production which had been neglected by the market and largely overlooked - even dismissed - by connoisseurs and scholars. Conventional wisdom identified the period of florescence for the Japanese woodblock print from the later $17^{\text {th }}$ century until the early part of the $19^{\text {th }}$ century. The print emerged as the medium of choice for afficionanados of Japan's demimonde, primarily offering depictions the theatre and brothel world with later forays into landscape and nature subjects. It was generally thought that with the mid-1 $19^{\text {th }}$ opening to the West both subject and technique of the Japanese print went into precipitous decline; the term "decadent" was frequently used to describe the print products of this period. Whatever the aesthetic perceptions of disappointed collectors, the traditional labour-intensive print making industry - a guild system comprised of publisher, designer, block cutter and printer - was in true decline, usurped by modern printing technology that enabled mass production of images which satisfied the needs of the public. The phenomenon of mass journalism overtook Japan in the last three decades of the $19^{\text {th }}$ century and the artist/designers who once formed the creative core of the old guild system now sought employment as illustrators for the new media giants. Although some continued to produce for a few surviving old-style publishers, none could rely on the hand produced woodblock print as a main-

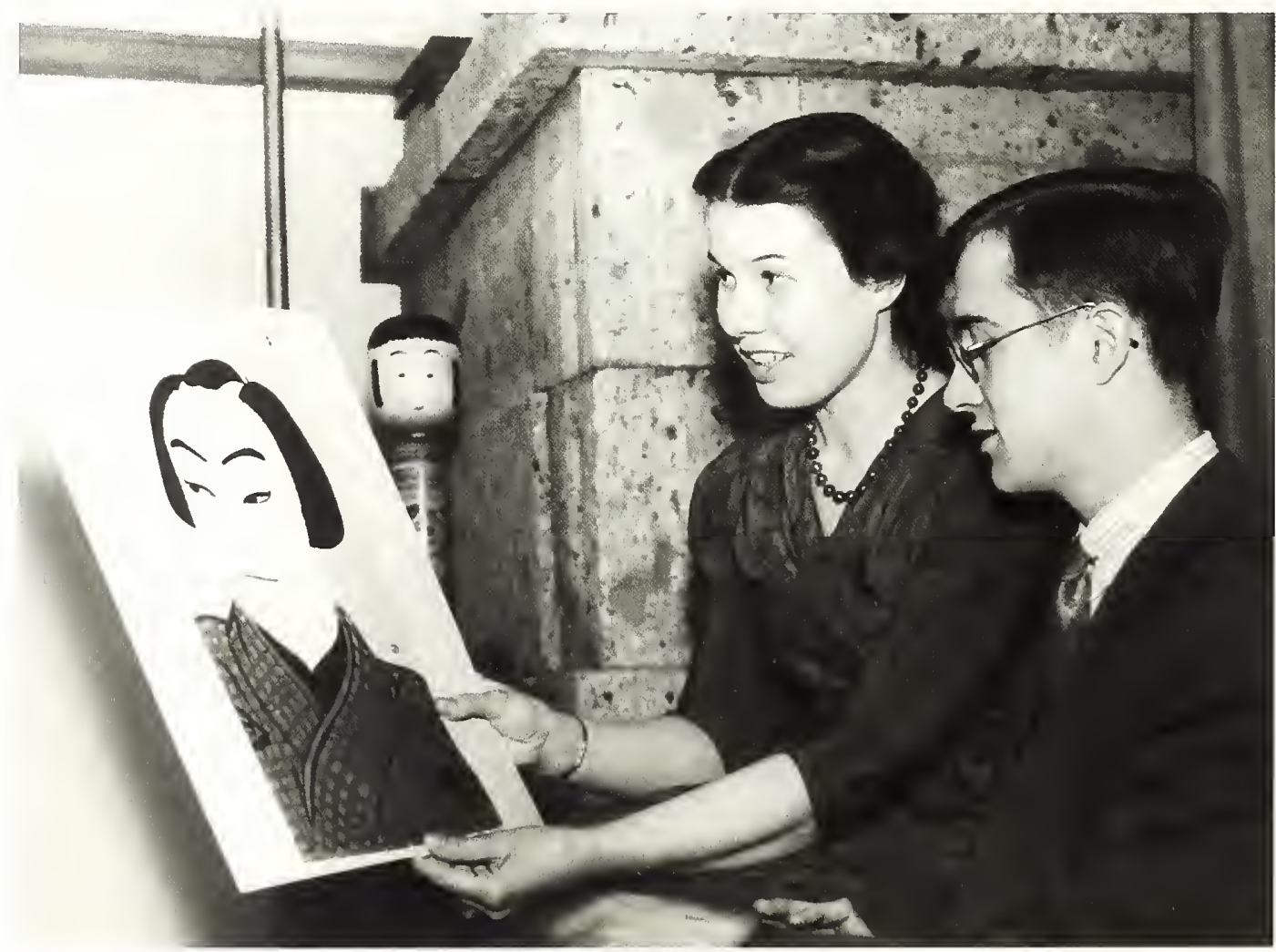



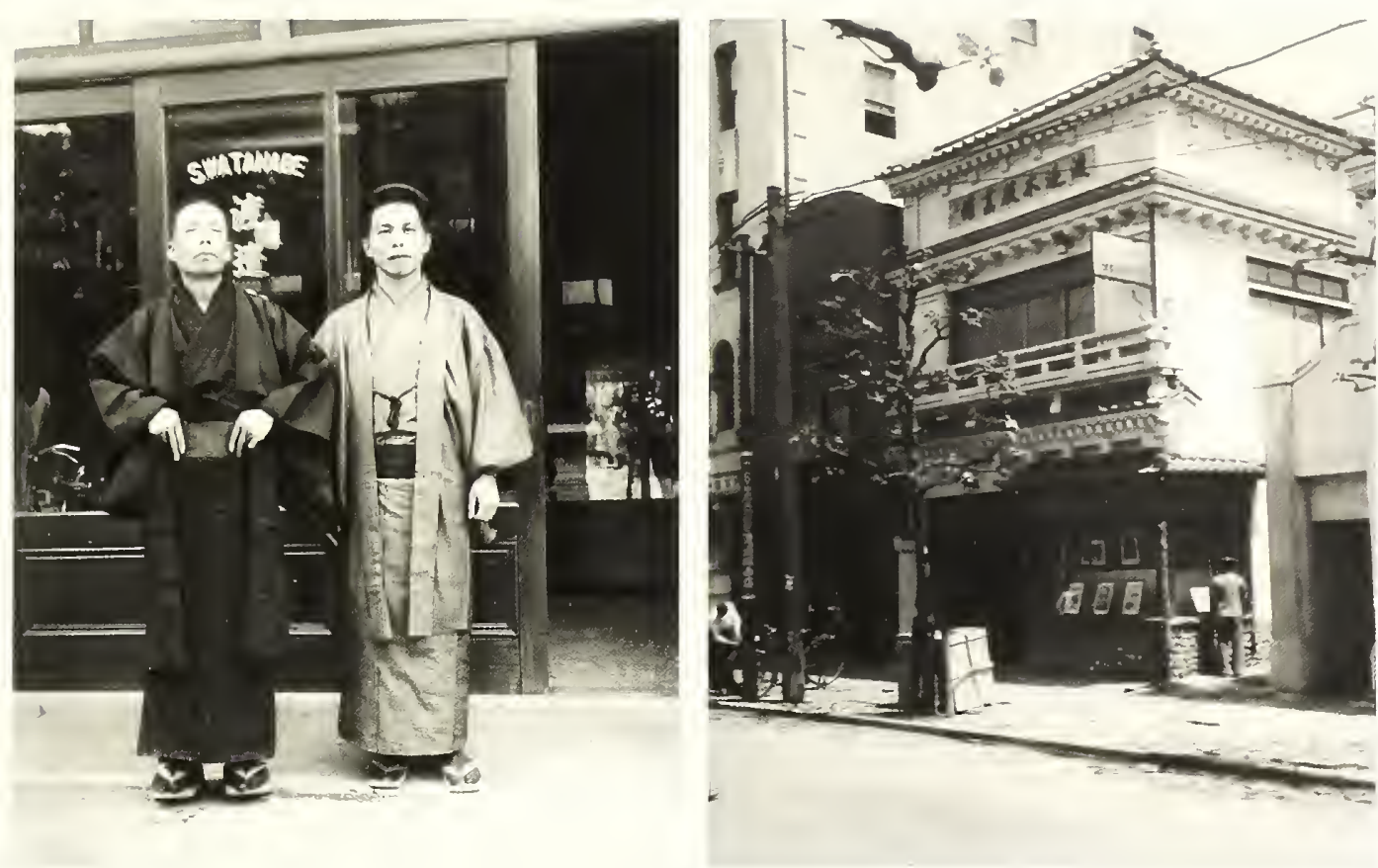

stay. Yet within that group of transitional artists there where such figures as Tsukioka Yoshitoshi, Kawanabe Kyōsai and Kobayashi Kiyochika, each of whom negotiated distinctive and often brilliantly subtle choices that infused bits of Western style composition and technique into their works. But used at their most effective, those techniques were more than tricks to attract new audiences; they were part of a visual inquiry into the best ways of expressing intensely felt perceptions of new realities. Muller, through his own instincts and through the mentoring of such rare collectors as Thomas Bates Blow, began to understand these neglected figures as true revolutionaries.

If the late $19^{\text {th }}$ century or so-called Meiji era prints (denoting the seminal modernizing reign of the Meiji emperor [1868-1912]) form one key element of Muller's collecting direction, the other, signalled by the immediate attraction of his first purchase of a Kawase Hasui (1883-1957) print, was to the movement largely organized by the print publisher and entrepreneur Watanabe Shōzaburō (1885-1962). It was Watanabe's genius to grasp especially the Western collector's nostalgia for a by-gone Japan, one that could be relatively affordable and accessible through a reinvigoration of the guild system approach to printmaking. Watanabe recruited talented young designers and painters to look again at modern Japan, but through the lens of pre-modern categories: female beauty, landscape, the animal world and theatre. This resulted in the Shin-hanga or "new print" movement. In retrospect, Muller formed a thoroughly instructive collection by grasping before anyone else how the seemingly disjointed and disparate parts of the roughly one hundred year long saga of visual exploration and confusion acutally congealed.
Fig. 3

Publisher Watanabe Shōzaburō, with his son, standing in front of his Tokyo print shop and publishing studio, 1940. Photograph by Rubert O. Mulle: from the Robert () Muller Papers. Freer Gallery of Art and Arthur M. Sackler Gallery Archives, Smichsoman Insciturion, Washongron, D, C

Fig. 4

View of publisher Watanabe Shōzaburō's print shop and publishing studio in Tokyo, 1940 Photograph by Robert O. Muller; from the Robert O. Muller Papers, Freer Gallery of Art and Arthur M. Sackler Gallery Archives, Smichsonian Inscitution, Washington, D.C 
Fig. 5

Muller and his wife, during their 1940 honeymoon trip to Japan, in the garden of artist ltō Shinsui's Tokyo home. They are flanked by major figures of the Shin-hanga movement. Left to right, back row: Moryama Tetsutaro (assistant to publisher Watanabe Shōzaburō); artist Kawase Hasui; Robert and Inge Muller; Shinsui and his wife, Itō Yoshiko. Left to right, front row: artist Kasamatsu Shirō and publisher Watanabe Photographel unknowir, from the Robert O. Muller Papers, Freer Gallery of Art and Arthur M. Sackler Callery Archives, Smithsonian Institution Washington, D. C.

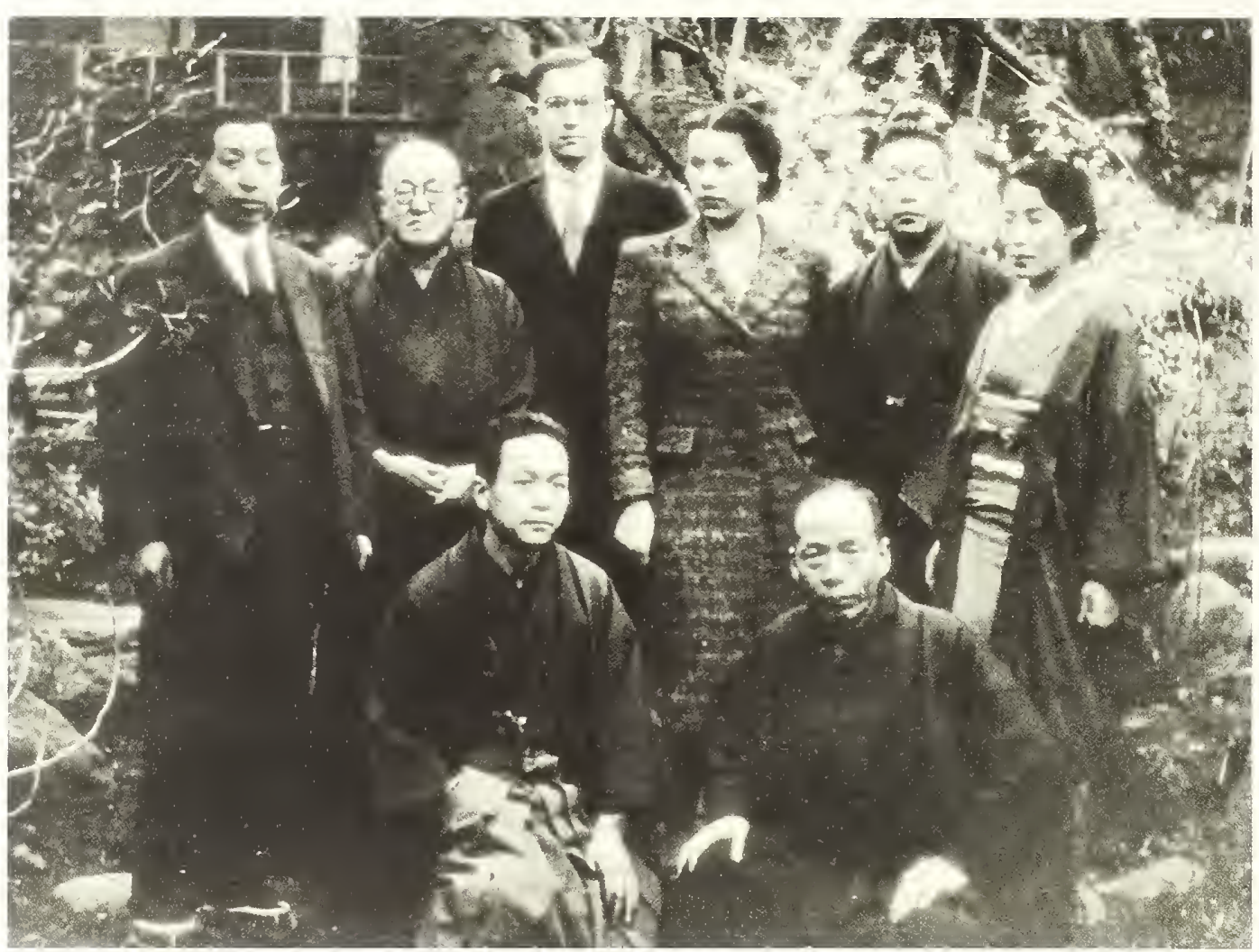

In 1940, Muller's burning passion for Shin-hanga took him at last to Japan where he brought his bride, Ingeborg Lee (1918-2004) for their honeymoon. During the course of this three-month visit, Muller met with all the major art publishers, print dealers and most especially the print artists themselves. Sort side-trips to Korea and China aboard Japanese troop ships and trains were highly dangerous but exciting excursions for the intrepid travellers.

Muller's plan was of opening a gallery in New York City devoted to modern Japanese prints. It was to be patterned after the Shima Art Company, located on West $57^{\text {th }}$ Street in New York, a retailer of modern Japanese prints where he had been steadily purchases since his first acquisition in 1931. The Japanese publishers were initially reluctant to offer him substantial discounts as they wanted to protect Shima, their main distributor in New York. However, Muller proved himself to be a most able negotiator. On 25 June 1940 he wrote about his success with the leading Tokyo publishers: "Times have changed, and I am here at the right time. The tourists aren't coming over, and Sumii [Shima's owner] isn't reordering." While actively acquiring multiple impressions of modern Japanese prints to offer to his American clients, he was saving the most exquisite impressions and rarest designs for himself, and in the process amassing the world's greatest collection of mid-20 2 th century prints. 
With the dire economic situation in Japan, the Mullers had great difficulty booking a return passage to America and extended their visit by two weeks. Not long after returning home from his hugely successful buying trip/honeymoon, he began selling these recent acquisitions at his new Robert Lee Gallery, located at 32 West $57^{\text {th }}$ street in New York. Unfortunately, his timing could not have been worse; the Japanese attack on Pearl Harbor on December 7, 1941 caused Muller to anxiously rush from his apartment to the gallery on that Sunday to remove the Japanese prints from the shop windows. Not long thereafter, he permanently closed the gallery.

Leaving New York in 1946 for the countryside of Connecticut, he bought an eighteen-acre farm complete with a 1710 farmhouse in which he helped raise his growing family of five children. He lived there for the rest of his life. From this idyllic spot, he reopened his print business and planned travelling sales exhibitions of carefully matted and labeled Shin-hanga prints to small colleges and schools. These prints presented reinterpretations of a rapidly disappearing Japanese landscape and modern revivals of the Ukiyo-e themes of women, Kabuki actors and flower-and-bird subjects that appealed to an American audience. In this manner, these prints became widely disseminated throughout the United States.

Wanting a more permanent establishment in 1962, Muller purchased Merwin's Art Shop in New Haven, Connecticut, a frame shop and print gallery whose owners were his clients. From this location adjacent to Yale University, he made loyal clients and friends from among the students and professors as well as dealers and collectors from around the world. In assuming ownership of Merwin's, Muller found himself in the heart of the Yale community and, inevitably, in contact with the Yale University Art Gallery. In the autumn of 1987, Dr. James Ulak was appointed assistant curator of the Asian collections. Soon thereafter, the Gallery's director, Mimi Gardner Neill (now Gates) organized a lunch in order to introduce her new curator to Muller. That first meeting led to many visits to Muller's farm in nearby Newtown, Connecticut and to exhibition collaborations with Muller at the Yale University Art Gallery. The relationship continued even after Ulak moved to The Art Institute of Chicago. From there he occasionally consulted Muller on questions about the Shin-hanga prints in Chicago's extensive collection. A 1995 move to the Freer and Sackler Galleries in Washington, D. C., put Ulak back in relative proximity to New Haven and he also occasionally met Muller at New York auctions.

In 1997, Muller decided that the time had come to find a permanent home for his massive collection. Swamped with numerous suitors from Asia, Europe and the United States, he decided to ask the advice of Japanese print and painting dealer, Joan B. Mirviss, who had been a close friend and colleague for more than twenty years. Thus began an almost year-long process of defining Muller's priorities and establishing a guideline for 
Fig. 6

The locus of Muller's collecting activities - storage, display, and study - was this renovated barn situated on his property in Newtown, Connecticut.

Whorograph by John Tsanres Free

Callery of Art and Arthur M. Sackle

ithery Smithsomian Inctuturion.

ishington, D C searching out the institution that could best satisfy them. The most important criteria were that the collections remain intact and stay in the United States. Care in assembling both prints and important ancillary material (including variant impression, print block, process books, drawings and studies) had produced an incredibly comprehensive group of immense value to researchers. Honed and edited over seven decades, the collection was more than the sum of its parts-it was an individual's vision.

Accordingly, Muller required that, in its final destination, the collection be housed in state-of-the-art storage facilities with access to professional conservation and curatorial oversight. Having sought only prints in pristine conditions and painstakingly cut his own mats, Muller would demand no less from the next generation of custodians. Furthermore, as Muller's pleasure was in research and in the communion achieved by viewing his holdings with kindred spirits, accessibility of this collection to both scholars and the public was identified as a critical requirement to be met by any future owner. Having generously lent his prints for exhibitions throughout the world as well as for publication in books and exhibition catalogues, the new owners would have to have a similar open-door policy. It soon became apparent to Muller that only a fully functioning major museum could meet these criteria.

In the autumn of 1999, Muller visited the Freer and Sackler. This provided an opportunity for Muller to survey the facilities of the galleries and to have a pleasant reunion

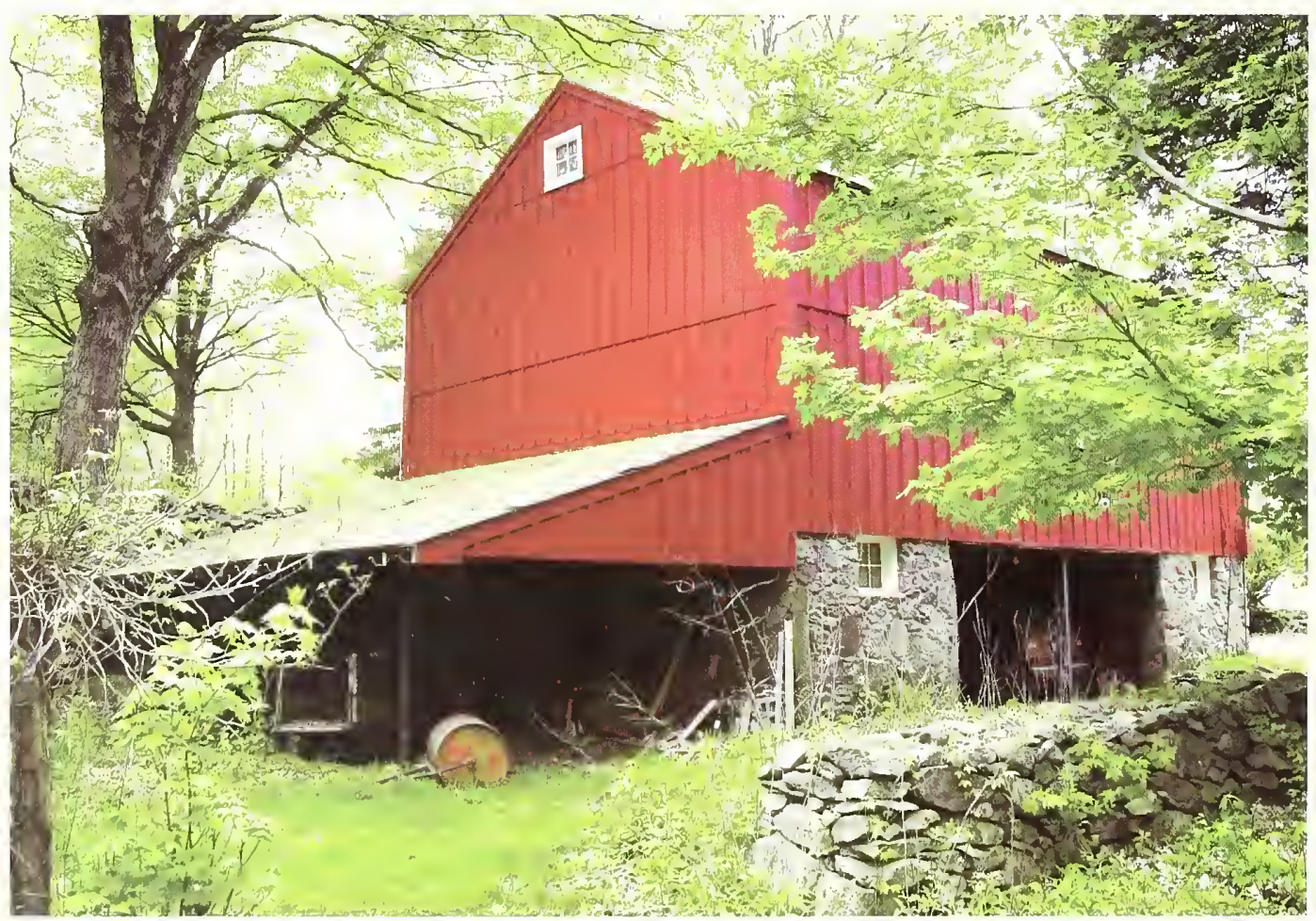


with Ulak. During this visit, the complex structural issues of the joint museum were carefully explained to him. Because of the conditions set by Charles Lang Freer that prohibit borrowing from or lending to the Freer Gallery, Muller noted at the time that if the collection was to go to Washington, the Sackler Gallery, with its more liberal lending policy, would be the obvious choice. After this visit, Muller decided that he needed to look no further. Negotiations were promptly started for the purchase of the entire print collection. However, at the time of Muller's death, no sale had yet been consummated. Those close to the discussions presumed that, in all probability, the collection would be dispersed through auction or private sale. Thus the art world was happily surprised to hear of the instructions contained in Muller's will: his print collection should go to the Freer Gallery of Art and the Arthur M. Sackler Gallery of the Smithsonian Institution in Washington, D. C. Muller's satisfaction with the operating procedures of the Arthur M. Sackler Gallery and its ability to perform as a worthy custodian is manifest in his will. The more than 4,000 prints and archival documents now constitute what is officially known as the Robert O. Muller Collection.

Muller's bequest is officially cast as "a gift to the nation". The shift of his collection from a lyrical setting in the Connecticut countryside to a place of prominence within the vast complex of the Smithsonian Institution may seem jarring. But now a large number of diverse visitors - generalists, tourists and scholars - can witness the passion that one citizen had for a world beyond his shores.

\footnotetext{
* This essay is an adaptation of an obituary authored by Joan B. Mirviss and James Ulak for the international Asian arts journal Orientations (September 2003, pp. 85-87). The authors are grateful to Orientations for permission to make use of this material.
} 
STAGE PRESENCE 
Kabuki was born as a bawdy entertainment played out on the riverbanks of Kyoto. As it evolved into a stable theatrical form in interior settings and on stages, the circumscribed space for choreographed action suggested a useful formula to artists for depicting dramatic narrative action. This "theatricality" in Japanese prints embraces not only the obvious depictions of actors in scenes of popular plays but also incorporates the strong influence these productions had on reportorial images in the late- $19^{\text {th }}$ and early- $20^{\text {th }}$ centuries. The challenge for those designers seeking to describe current events was found in the ever-growing popularity of still photographs and cinema.

Of all the print forms "revived" by Watanabe Shözaburō and others of the Shin-hanga school, theatrical prints by virtue of their depiction of traditional staging - remained the most stable in their content. Nonetheless, while modern print designers drew heavily on traditional conventions for their actor portraits, they also strove to reveal the personality behind the makeup and costume. Faces became less schematic and more particular, taking on volume, modelling, and individuality - and this distinguished the Shin-hanga portraits from their print ancestors. 
TOYOHARA KUNICHIKA (1835-1900)

Onoe Kikugorō $V$ as Hanai Oume

and Onoe Matsusuke IV as Hakoya Minekichi

Japan, 1888

Woodblock print; ink and colour on paper

$36 \times 71.7 \mathrm{~cm}$

Arthur M. Sackler Gallery, Smithsonian Institution,

Washington D.C.; Robert O. Muller Collection

Inv. no. \$2003.8.2737a-c

In a Kabuki play, a ripped umbrella signifies that the character holding it is destined to be slain. Even without this obvious prompt, Kunichika's contemporaries would have brought a complete understanding of and even relish for the dramatic details recounted in this scene - the June 9, 1887, slaying of Yasugi Minekichi by his employer, Hanai Oume, the twentyfour-year-old proprietress of a Tokyo teahouse and a former geisha. The beautiful Oume claimed self-defence, contending that Minekichi, who was thirty-four, had been stalking her and, on that fateful night, attacked her with a knife. The prosecution countered the two had long been lovers and Oume had grown weary of his parasitic dependence. The murder, subsequent trial, and conviction of Oume were much publicized, and oglers crowded the courthouse on the day the verdict was delivered. Based on a scene from the play Tsuki to ume kaoru oboroyo ("The fragrant night of the moon and plum").
TOYOHARA KUNICHIKA (1835-1900)

Onoe Kikugorō V as Tenjiku Tokubei

Japan, 1891

Woodblock print; ink and colour on paper

$36 \times 72.4 \mathrm{~cm}$

Arthur M. Sackler Gallery, Smithsonian Institution,

Washington D.C.; Robert O. Muller Collection

Inv. no. $\$ 2003.8 .2741 \mathrm{a}-\mathrm{c}$

The character Tenjiku Tokubei is inspired by the adventures of an early $17^{\text {th }}$-century merchant sailor and his five-year journey across the waters of Asia, purportedly as far away as India. This historical figure - whose distant travels and safe return would have been regarded as doubly rare at that time in Japan - is fictionally transformed into a complex villain.

There is a kernel of historical truth upon which this character has been created, but the playwright imagines a variety of accretions that Tokubei acquired from his travels: a Korean lineage; membership in a banned Christian sect; and finally, well into the already phantasmagorical plot, a giant magical toad with whom Tokubei conspires to overthrow the shogunate.

Based on a scene from the play Tenjiku Tokubei ikoku banashi ("Tale of Tokubei from lands afar"). 

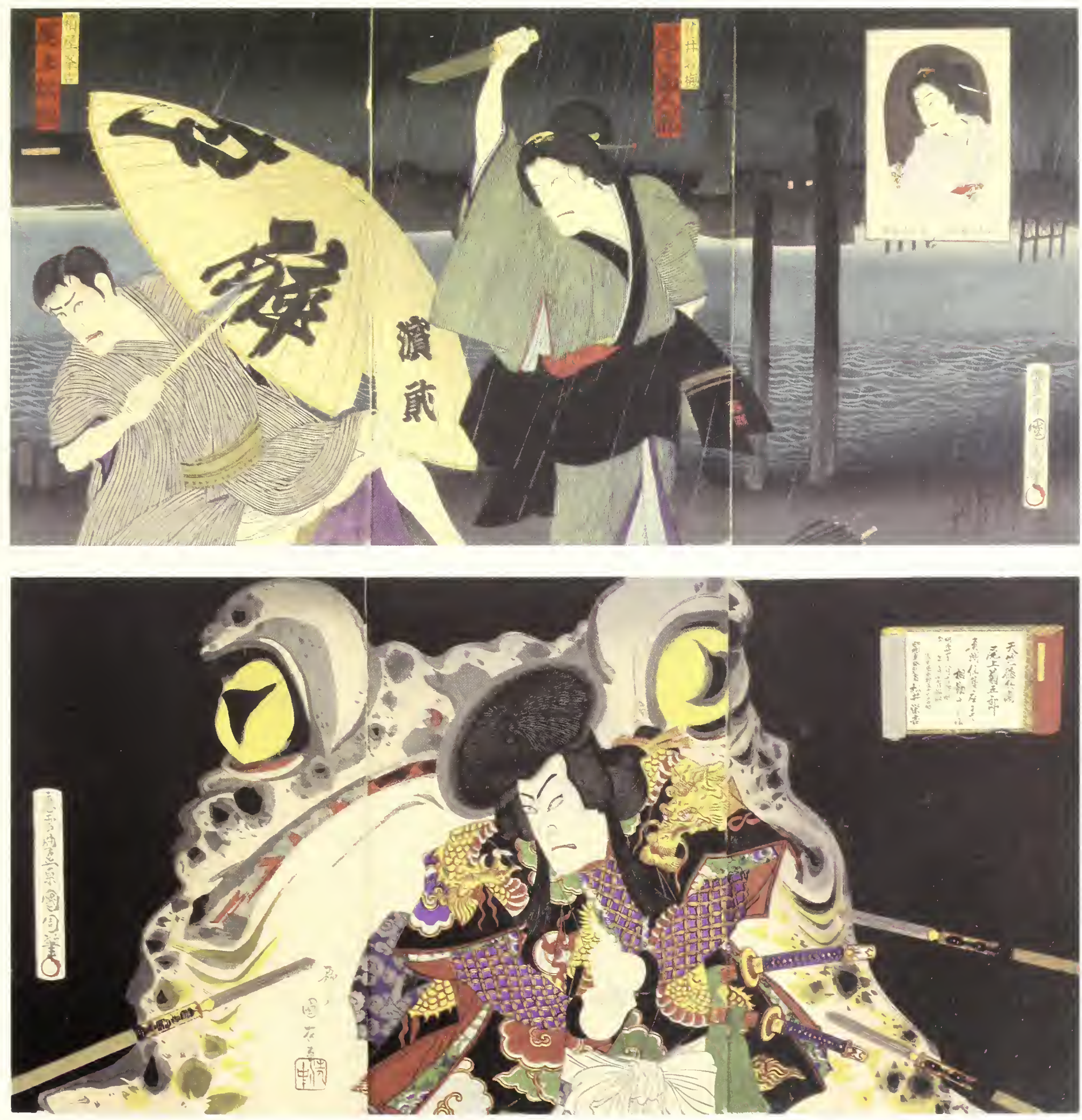

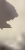
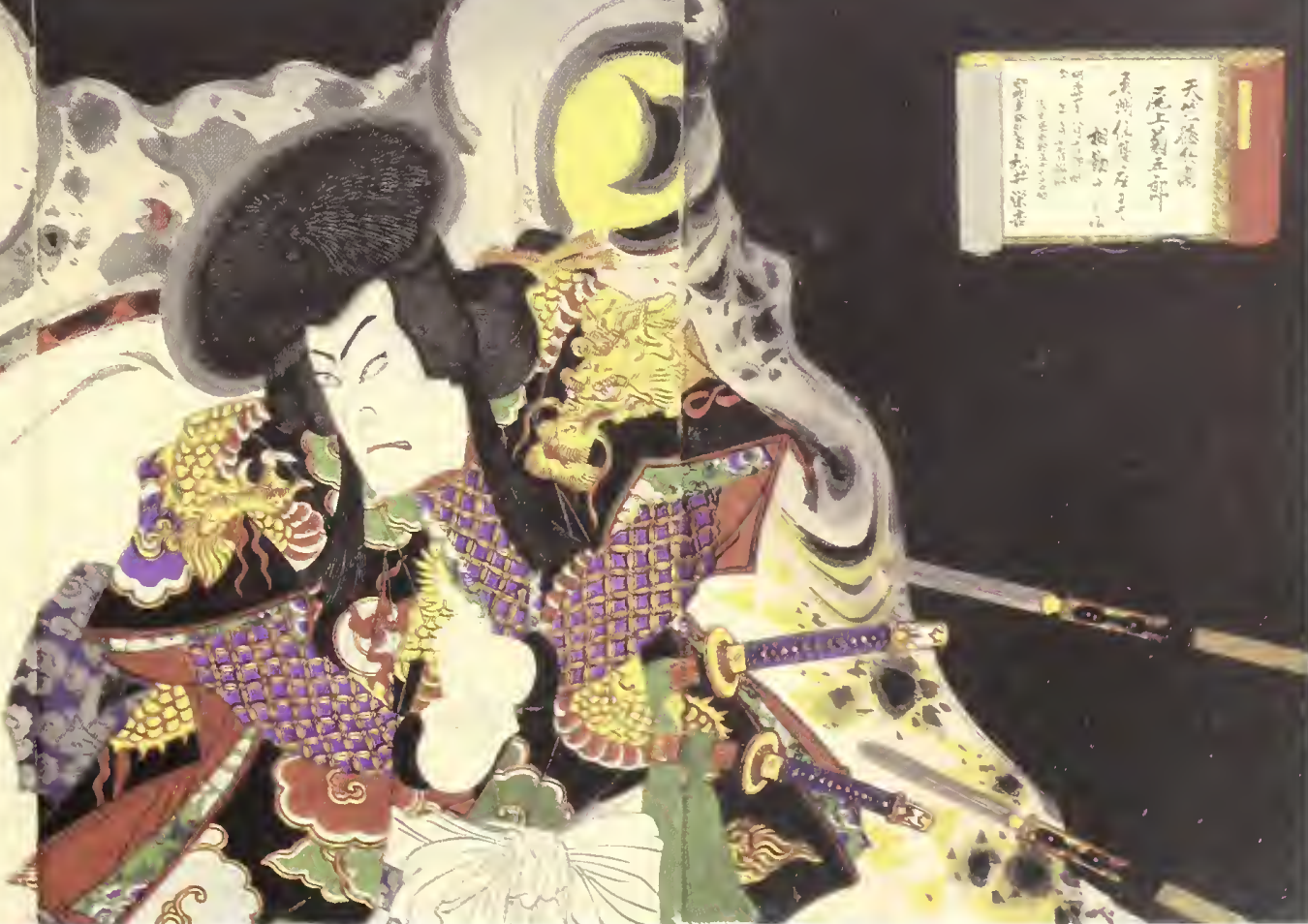
TOYOHARA KUNICHIKA (1835-1900)

Ichikawa Sadanji I as Akiyama Kii-no-kami,

\section{The scene of flames}

From the series 'New plays of the Meiji-za' (Meiji-za shinkyōgen) Japan, 1894

Woodblock print; ink and colour on paper

$36 \times 71.8 \mathrm{~cm}$

Arthur M. Sackler Gallery, Smithsonian Institution,

Washington D.C.; Robert O. Muller Collection

Inv. no. \$2003.8.2719a-c

Kunichika was one of the last traditional Ukiyo-e printmakers to concentrate on the actor genre - at a time when it was being challenged by the popularity of photographs. He responded to the competitive pressure with innovative strategies. Here, he challenges the traditional one-character-per-sheet convention used in the triptych format. Instead, his three-quarter-length portrait of the actor extends across and dominates the three separate units. The theatricality of this portrait, with its blazing background, was something photographic realism could not capture. The one hundred years of warfare between clans, which brought Japan to unification at the end of the sixteenth century, provided rich material for literary and dramatic productions. Here, Akiyama Kii-no-kami, one of the valiant retainers of the Takeda clan, fights against the ultimately overwhelming odds brought upon him by Oda Nobunaga in a battle in 1582.

Based on a scene from the play Köshüryū Takeda makuhari ("The Takeda clan under the Kōshū banner").
TOYOHARA KUNICHIKA (1835-1900)

Ichikawa Danjurō IX as Mongaku Shōnin

From the series 'The new Kabuki eighteen' (Shin Kabuki

jühachiban no uchi)

Japan, 1896

Woodblock print; ink and colour on paper

$35.9 \times 71.8 \mathrm{~cm}$

Arthur M. Sackler Gallery, Smithsonian Institution,

Washington D.C.; Robert O. Muller Collection

Inv. no. \$2003.8.2725a-c

The play to which this print refers is based on the historic rivalry between Minamoto Yoritomo (1147-1799) and his younger brother Yoshitsune (1159-1189), who belonged to one of two great warrior families engaged in a battle for ultimate political control of Japan. With family power established, internecine suspicions erupted and Yoshitsune fled an assassination attempt by his brother. Together with his loyal retainer Benkei and a handful of other guardians, Yoshitsune journeys to the hinterlands disguised as a baggage carrier for his entourage of "mountain monks." When challenged at a mountain pass by sentries, Benkei fends off their assault and unfurls a blank scroll, claiming it is a list of subscribers to his religious sect - proof of his credentials. Moments later, to complete the deceit, Benkei beats his young master in a clever reversal of hierarchical rank. Hints of the attacking sentries, indicated by topknots and hands, provide humorous counterpoint to Benkei's sweeping gesture.

Based on a scene from the play Mongaku kanjinchö ("Mongaku's subscription list"). 

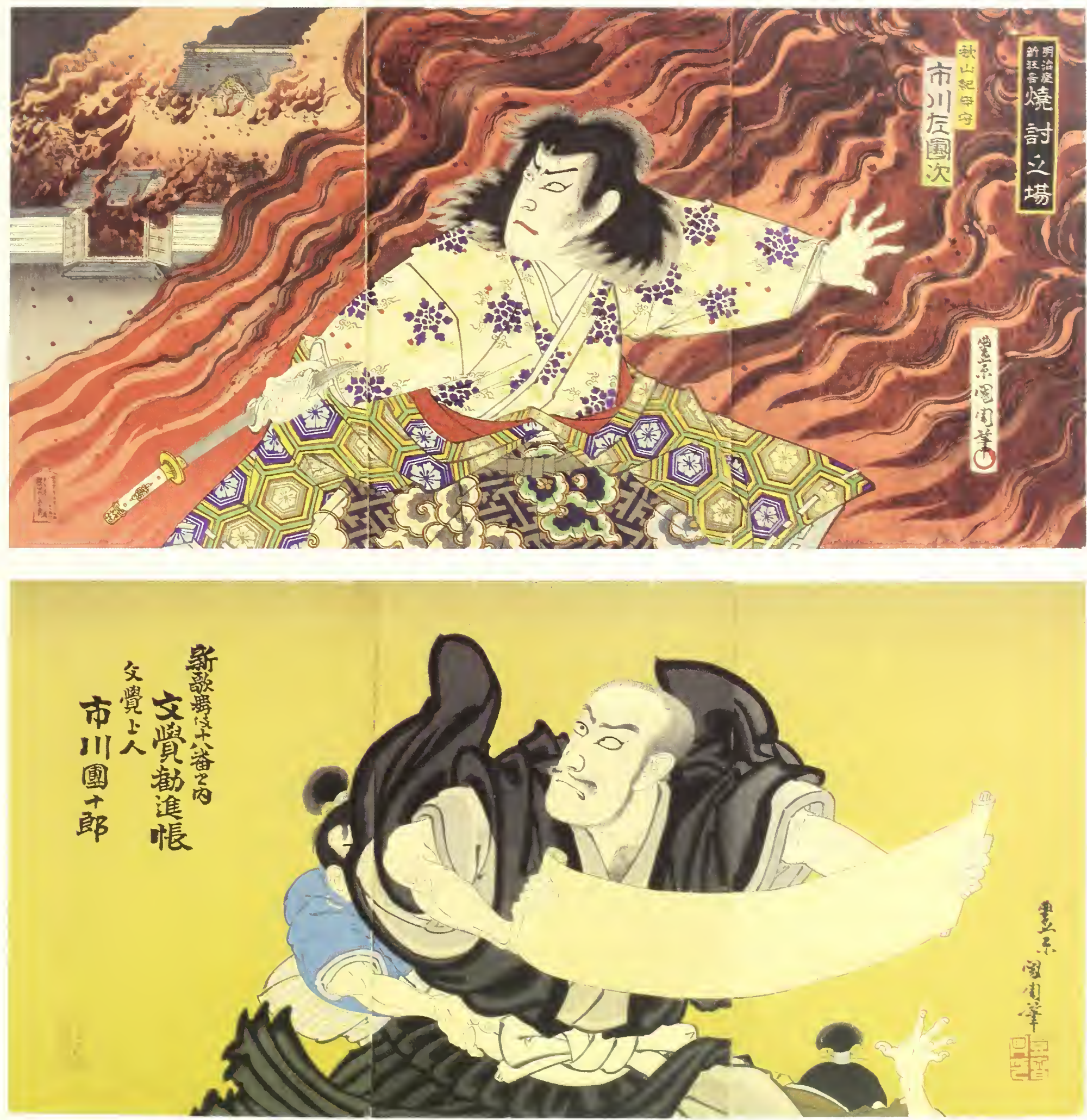
TOYOHARU KUNICHIKA (1835-1900)

Ichikawa Danjūrō IX as Fuwa Banzaemon

Fashionable modern clothing

Japan, 1885

Woodblock print; ink and colour on paper

$36.5 \times 23.8 \mathrm{~cm}$

Arthur M. Sackler Gallery, Smithsonian Institution,

Washington D.C.; Robert O. Muller Collection

Inv. no. $\$ 2003.8 .2631$

Images of actors offstage, either preparing in the "green room" or out in public, gained popularlity in late- $18^{\text {th }}$-century Japan. By the middle of the $19^{\text {th }}$ century this novelty had all but faded to convention, as this highly stylized print suggests. The large oval mirror in the dressing room is virtually an abstract background form; nothing is reflected in it. The calligraphy on the partially visible banner indicates a sponsor quite likely a textile merchant. This elaborate and outrageous caricature, at the expense of realistic depiction, conforms to late- $19^{\text {th }}$-century print fashion.

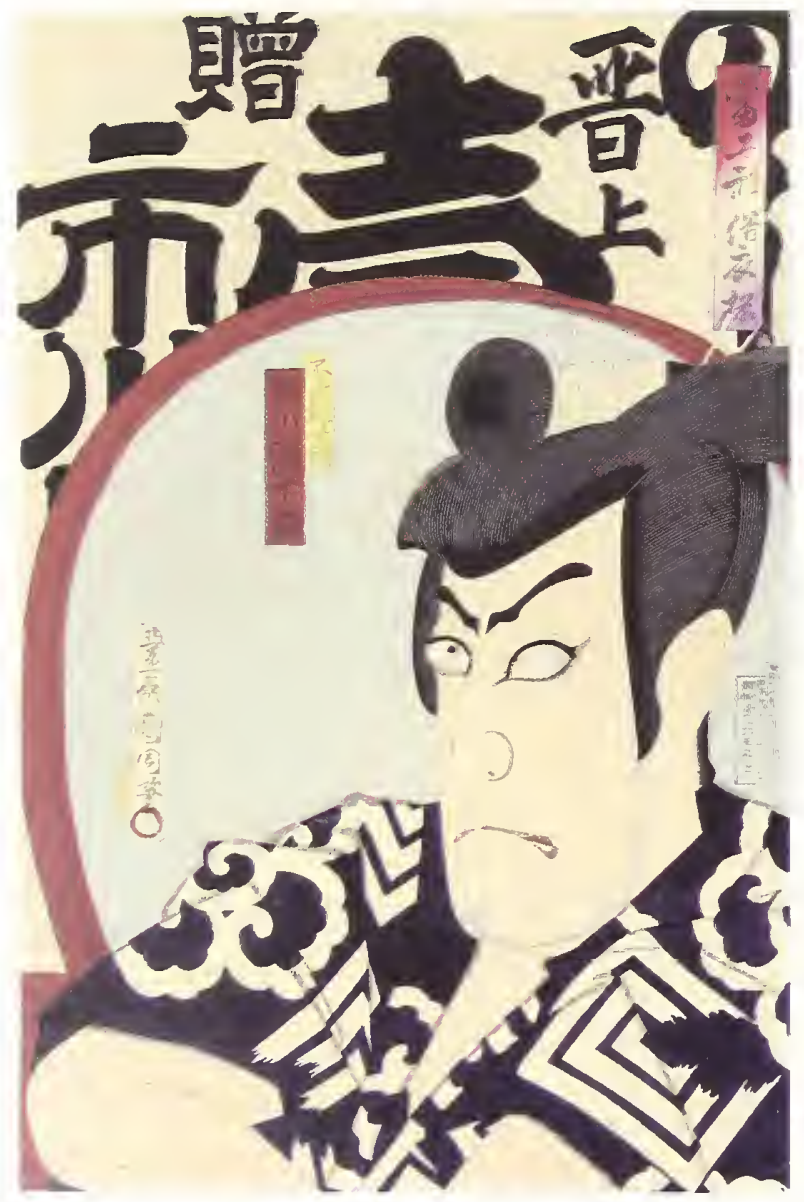

TOYOHARA KUNICHIKA (1835-1900)

The Meiji emperor

From the series 'Real portraits of modern beauties' (Imayō

bijin shashinkan)

Japan, 1881

Woodblock print; ink and colour on paper

$35.9 \times 24.1 \mathrm{~cm}$

Arthur M. Sackler Gallery, Smithsonian Institution,

Washington D.C.; Robert O. Muller Collection

Inv. no. \$2003.8.2697

This print testifies to the startling and dramatic changes that occurred in Japanese culture as it reopened a dialogue with the outside world at the end of the $19^{\text {th }}$ century. In any earlier era this portrait of a living emperor presented in a format reserved for Kabuki actors would have been considered blasphemous. In the 1870 s Japanese officials sought cultural parallels with Western art forms and elevated Kabuki to the status of a national theatre. With this opportunistic reappraisal came a certain reform and cleansing, and Kabuki was granted a passport to elite social realms. In 1887 Emperor Meiji became the first of Japan's emperors to attend a Kabuki performance. That impulse notwithstanding, Kunichika's casting the emperor almost as a matinee idol is one of the most extreme expressions of that trend.

\section{TOYOHARA KUNICHIKA (1835-1900)}

\section{Ichikawa Danjūrō IX as Sanada Yukimura}

from the series 'Real portraits of modern actors' (Imayō haiyū shashinkan)

Japan, 1881

Woodblock print; ink and colour on paper

$35.6 \times 24.1 \mathrm{~cm}$

Arthur M. Sackler Gallery, Smithsonian Institution, Washington D.C.; Robert O. Muller Collection Inv. no. \$2003.8.2694

As early as the 1870 s, designers of actor prints were launched into a competition with photography, which was fast becoming a popular form of actor portraiture. Consequently, print designers were required to be ever more resourceful and inventive in the presentation of subjects. In this portrait of actor Danjürō IX, Kunichika plays with the Japanese word shashin in the title and cartouche. The word means "true rendering", but its variant forms were the standard nomenclature for camera and photography. The printmaker invites his audience to share in his ironic jab at his competition.

Based on a scene from the play Chausuyama gaika no jindate ("Preparing for battle at Mount Chausu with a victory song"). 

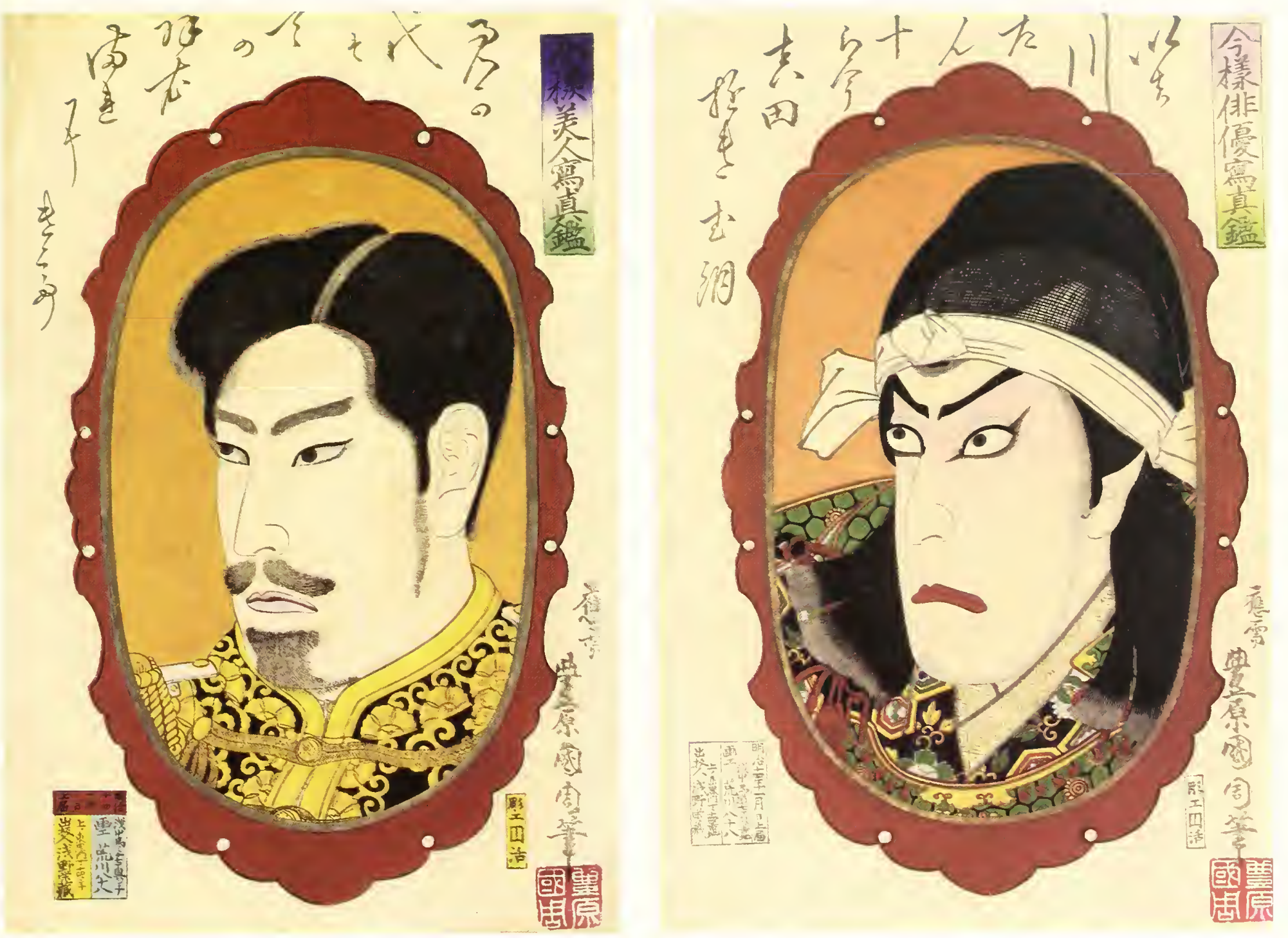
YOSHIKAWA KANPŌ (1894-1979)

Jitsukawa Enjaku II as Igami no Gonta

Japan, 1923

Woodblock print; ink and colour on paper

$39.7 \times 26.2 \mathrm{~cm}$

Arthur M. Sackler Gallery, Smithsonian Institution,

Washington D.C.; Robert O. Muller Collection

Inv. no. $\$ 2003.8 .3628$

This modern actor in a $20^{\text {th }}$-century production looks as if he were straight out of the $18^{\text {th }}$ century. Kanpō worked deeply in a narrow range, providing portraits that verged on verisimilitude. In this image, however, the dimensionality and modelling featured in his more adventurous prints is absent. Actor portraits were the staple subject for Osaka printmakers, who were the only serious rivals to the Edo print industry. Aware of his distinctive artistic lineage, Kanpō seems dedicated to reminding his audience of the specific characteristics of the pre-modern Osaka style. While the range of prints varied, there was nonetheless an identifiable regional manner, which included a subdued palette and a penchant for softer lines, rather than the angular expressions of the Edo (present-day Tokyo) counterparts.

Based on a scene from the play Yoshitsune senbon zakura ("Yoshitsune and the thousand cherry trees").

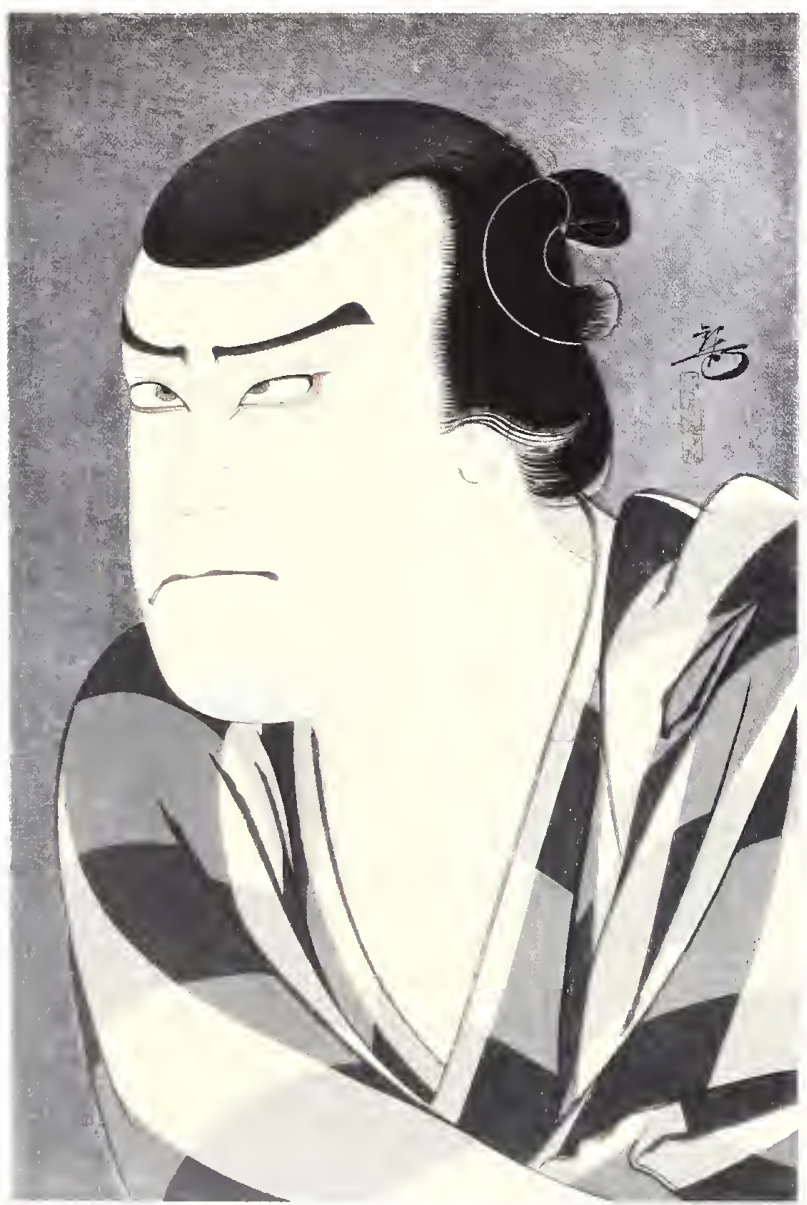

YOSHIKAWA KANPŌ (1894-1979)

Kataoka Gadō XII as Miyuki

Japan, 1924

Woodblock print; ink and colour on paper

$40 \times 27 \mathrm{~cm}$

Arthur M. Sackler Gallery, Smithsonian Institution,

Washington D.C.; Robert O. Muller Collection

Inv. no. $\$ 2003.8 .3631$

The actor Kataoka Gadō XII here appears in one of his most acclaimed roles, that of the blind koto player Miyuki, the beautiful daughter of a prominent family. Torn from her true love and required by her family to marry another man, she flees. Blinded by her incessant crying, she wanders from inn to inn as a koto player - a fact gently referenced by the artist's inclusion of plectra, or picks, on Miyuki's fingers. Gadō, who played female roles, was renowned for his exceptionally beautiful countenance and his ability to affect a feminine voice. His personality was distinguished by an air of inexplicable sorrow, which seemed to enhance and inform the wide range of delicate female roles that he pursued.

Based on a scene from the play Shoutsushi Asagao banashi ("Recreating the true story of Asagao").

YOSHIKAWA KANPŌ (1894-1979)

Nakamura Ganjirō I as Kamiya Jihei

Japan, 1923

Woodblock print; ink and colour on paper

$39.8 \times 27 \mathrm{~cm}$

Arthur M. Sackler Gallery, Smithsonian Institution,

Washington D.C.; Robert O. Muller Collection

Inv. no. \$2003.8.3632

"Under the headcloth, Japan's finest face" - so praised a poem about Nakamura Ganjirō I in his famed portrayal of the tormented Kamiya Jihei. A married man with two children, Kamiya Jihei has a tragic affair with the courtesan Koharu that results in the lovers' double suicide. As a Kyoto-based artist, Kanpō took great pride in featuring actors who were masters of the regional Kabuki theatre. Ganjirō was a natural candidate for Kanpō's attention, as he was the dominant actor in the Kansai region - an area that included Osaka, Kyoto, and Kobe - during both the Meiji and Taishō periods (1868-1912; 1912-1926).

Based on a scene from the play Shinjū tenno Amijima ("The love suicide at Amijima"). 

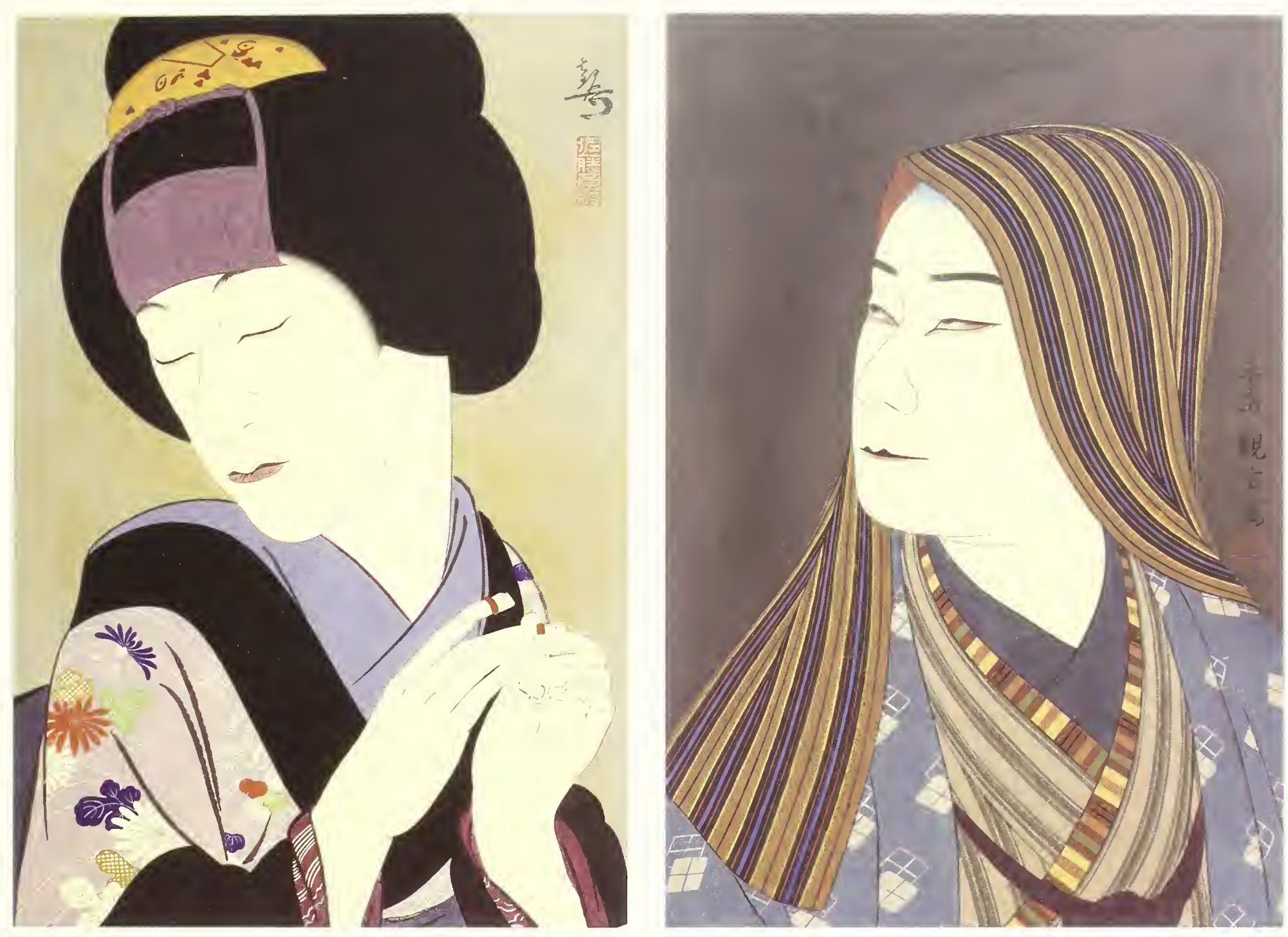
NATORI SHUNSEN (1886-1960)

Nakamura Kichiemon I as Takechi Mitsuhide

From the series 'Collection of portraits of actors by Shunsen'

(Shunsen nigao shü)

Japan, 1925

Woodblock print; ink and colour on paper

$38.1 \times 25.9 \mathrm{~cm}$

Arthur M. Sackler Gallery, Smithsonian Institution,

Washington D.C.; Robert O. Muller Collection

Inv. no. \$2003.8.1547

The actor Nakamura Kichiemon I was renowned for injecting new life and psychological realism into roles that had become stale and derivative. The plot of the Kabuki play is loosely based on the rebellion of retainer Akechi Mitsuhide (15281582) against his lord Oda Nobunaga (1534-82), then Japan's most powerful warrior general. (In the play, the protagonist's surname is altered from Takechi to Akechi.) Mitsuhide - the victim of repeated and baseless assaults by his tyrannical master - is ordered to drink sake from a tub reserved for washing horses. Later, in the image portrayed here, the designer captures the pivotal moment when, infuriated and ready to explode, Mitsuhide decides to seek revenge for suffered ignominies. Assigned to pursue the enemy in distant Takamatsu, Mitsuhide turned around his forces in a surprise attack on his master, a move that led to Nobunaga's death at Honnoji, a temple in Kyoto. Shunsen's style, which favoured a modern, almost abstractionist economy of line and other graphic techniques, supports the psychological exploration of the actor and his role.

Based on a scene from the play Toki wa ima kikyō no hataage ("The banner of rebellion").

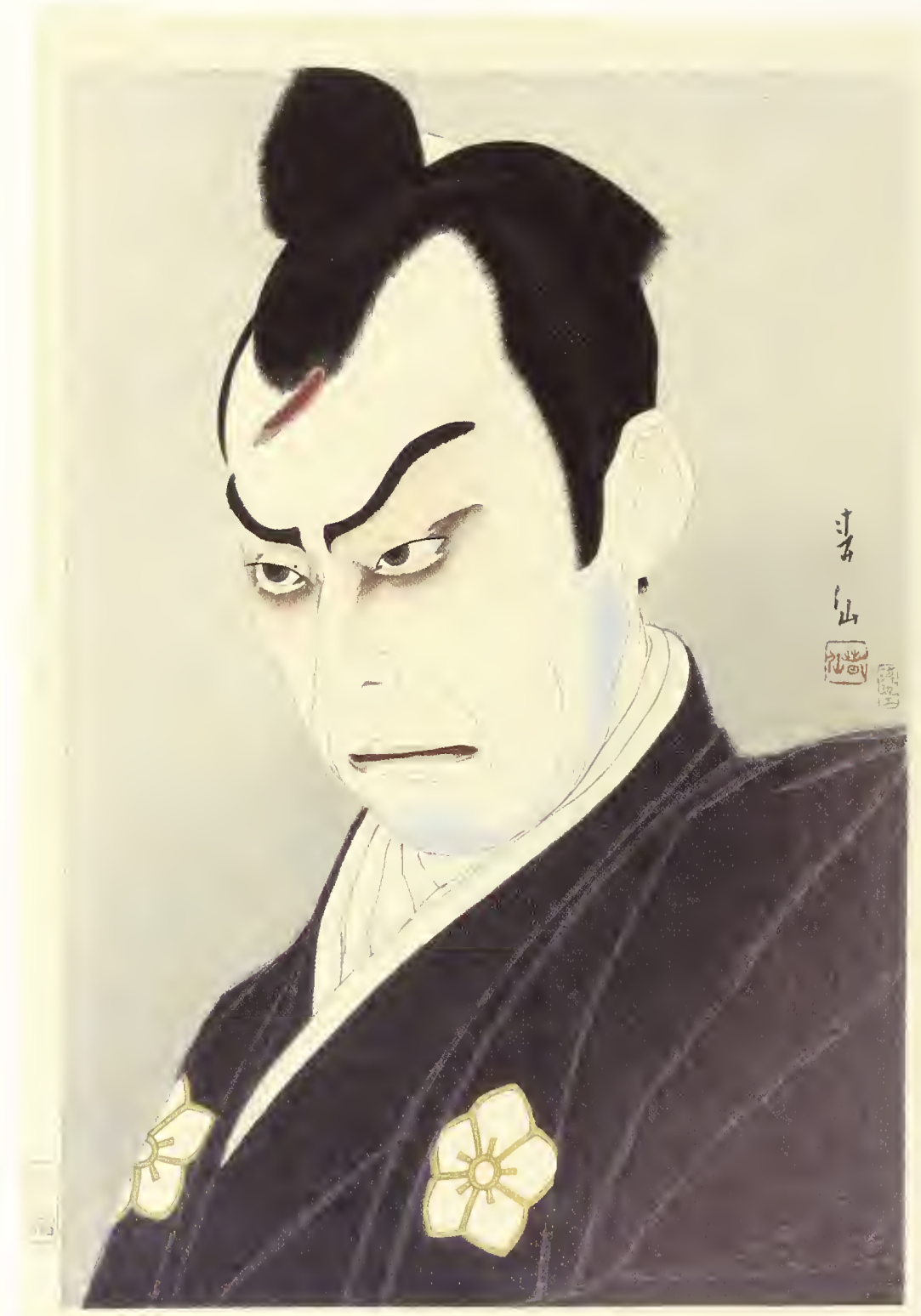




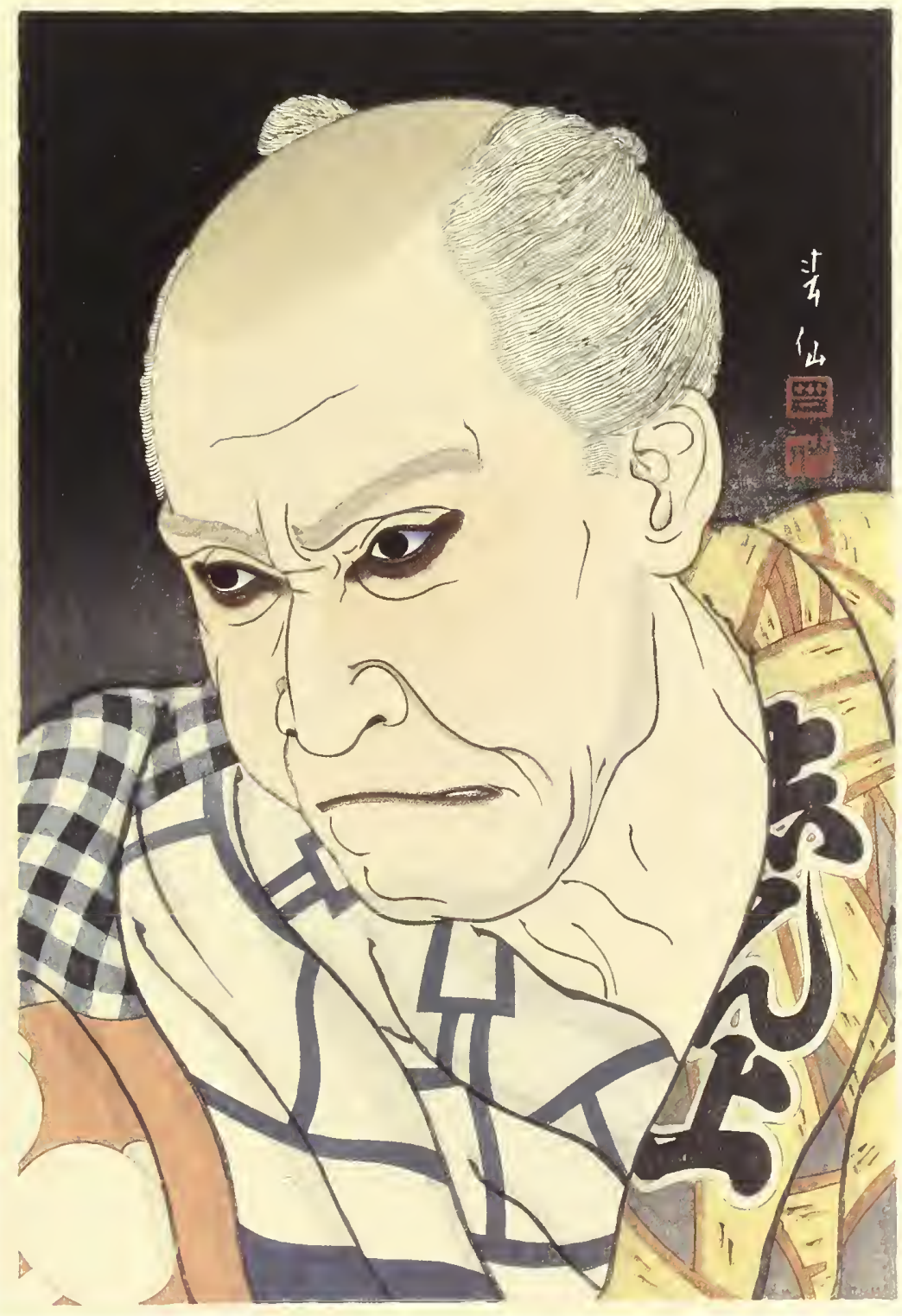

NATORI SHUNSEN (1886-1960)

Onoe Matsusuke IV as Chōbei

From the series 'Collection of portraits of actors by Shunsen'

(Shunsen nigao shū)

Japan, 1925

Woodblock print; ink and colour on paper

$37.8 \times 25.7 \mathrm{~cm}$

Arthur M. Sackler Gallery, Smithsonian Institution, Washington D.C.; Robert O. Muller Collection

Inv. no. 52003.8 .1548

Shunsen creates the impression of age by describing his subject through linear drawing and modelling techniques. The head is balanced on a colourful graphic ensemble of the figure's clothing - calligraphy and pattern forming a pediment upon which the sculpture-like head is based. Chöbei is a landlord, a member of the merchant class, and a type of Kabuki character distinguished by an aptitude for resourcefulness and wisdom in resolving complex interpersonal entanglements. This stock role provided entertaining self-justification for the genius of Edo merchants. The merchant class was the economic engine of the Edo society, but under the Confucian value system it occupied the lowest rung, after warriors, farmers, and artisans.

Based on a scene from the play Kiwametsuki Banzui Chöbei ("The renowned Banzui Chōbei"). 
NATORI SHUNSEN (1886-1960)

Jitsukawa Enjaku II as Danshichi

From the series 'Collection of portraits of actors by Shunsen'

(Shunsen nigao shü)

Japan, 1926

Woodblock print; ink and colour on paper

$38.1 \times 25.9 \mathrm{~cm}$

Arthur M. Sackler Gallery, Smithsonian Institution,

Washington D.C.; Robert O. Muller Collection

Inv. no. \$2003.8.1552

Kabuki audiences familiar with Edo custom would recognize Danshichi as belonging to a class of chivalrous and benevolent otokodate, pseudo samurai eager to fight on behalf of unprotected, ordinary citizens. In this play, the fiercely loyal Danshichi attempts to rescue a fugitive courtesan who is the lover of his friend's son. She has been abducted by none other than Danshichi's wicked father-in-law, Giheiji. Danshichi offers to pay Giheiji in exchange for her freedom but cannot produce the ransom money. Mercilessly taunted by Giheiji, Danshichi becomes enraged and slashes him with a sword. Shunsen's presentation of the unshaven character captures the image of the otokodate as a street tough and fearless commoner.

Based on a scene from the play Natsumatsuri Naniwa kagami ("The summer festival, a mirror of Naniwa").

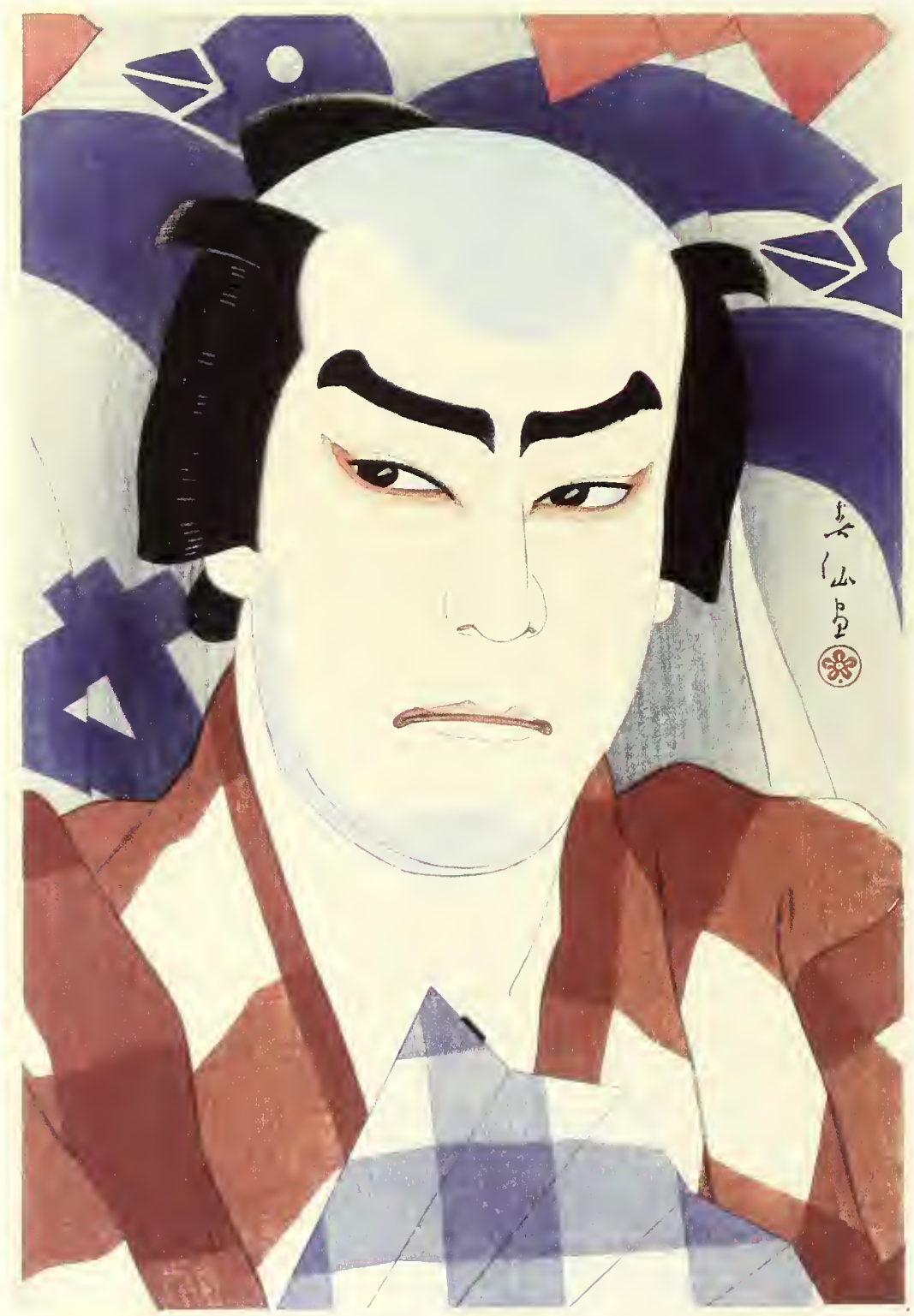




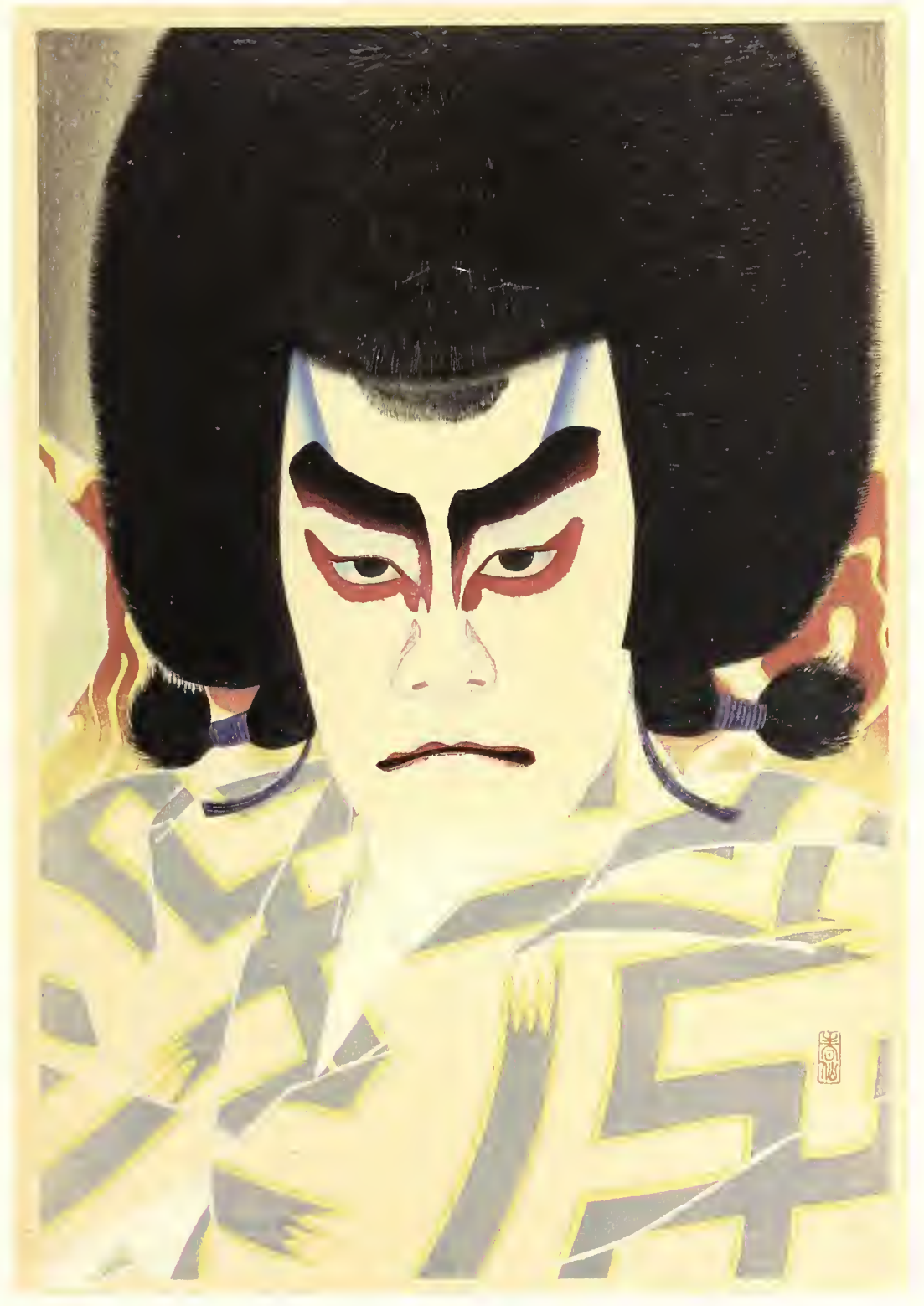

(4) NATORI SHUNSEN (1886-1960)

Ichikawa Sadanji II as Narukami

From the series 'Collection of portraits of actors by Shunsen'

(Shunsen nigao shü)

Japan, 1926

Woodblock print; ink and colour on paper

$38.1 \times 25.7 \mathrm{~cm}$

Arthur M. Sackler Gallery, Smithsonian Institution,

Washington D.C.; Robert O. Muller Collection

Inv. no. 52003.8.1549

The actor Ichikawa Sadanji II (1880-1940) is shown here in the role of Narukami, a crazed monk who is determined to overthrow the emperor. The audience would instantly have decoded the dramatic face painting (kumadori) and outlandish hairstyle as conventional signals of villainy. The symbolic colour scheme of the face provides additional clues - red for strength and blue for evil intent. The strong decorative quality of Shunsen's works reflects the 1920s taste for measured design in Kabuki production values. Those were decidedly more toned down from the garish extremes of the preceding Meiji era (1868-1912). Based on a scene from the play Narukami ("The Thunder God"). 
NATORI SHUNSEN (1886-1960)

Ichikawa Ennosuke as Kakudayū

From the series 'Collection of portraits of actors by Shunsen'

(Shunsen nigao shū)

Japan, 1927

Woodblock print; ink and colour on paper

$37.6 \times 25.7 \mathrm{~cm}$

Arthur M. Sackler Gallery, Smithsonian Institution,

Washington D.C.; Robert O. Muller Collection

Inv no. $\$ 2003.8 .1555$

The actor's head seems to be a construct of parts brought together in a forceful whole, indicating Shunsen's penchant for assembling forms - as if they were elements of a collage. Kakudayū, the character played by Ichikawa Ennosuke, is a former samurai turned bandit, murderer, and jail breaker. The plot revels in Kakudayū's villainy - he sells his daughter into prostitution, attempts to murder his wife, and is otherwise thoroughly scurrilous. As the magistrate Toyama and his lieutenants close in on him, Kakudayū disguises himself as a blind monk. Here, Kakudayū brandishes his knife, which he has concealed in his walking stick.

Based on a scene from the play Tôyama-zakura Tenpō nikki ("The Tenpō-era diary of the Toyama cherry blossoms").

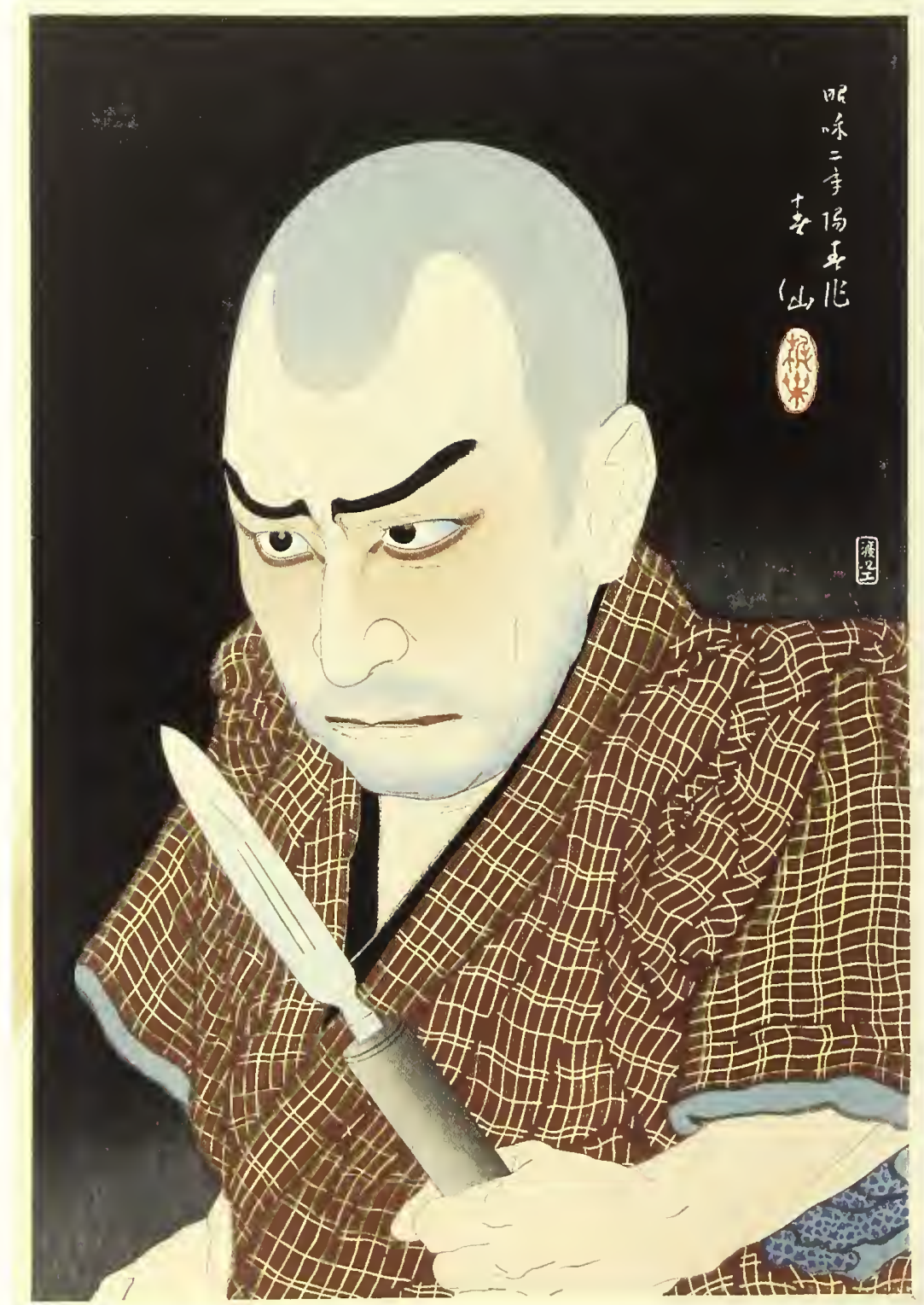


NATORI SHUNSEN (1886-1960)

Ichikawa Kigan (Onimaru) V as Otomi

From the series 'Collection of portraits of actors by Shunsen'

(Shunsen nigao shū)

Japan, 1927

Woodblock print; ink and colour on paper

$37.9 \times 25.4 \mathrm{~cm}$

Arthur M. Sackler Gallery, Smithsonian Institution,

Washington D.C.; Robert O. Muller Collection

Inv. no. \$2003.8.1556

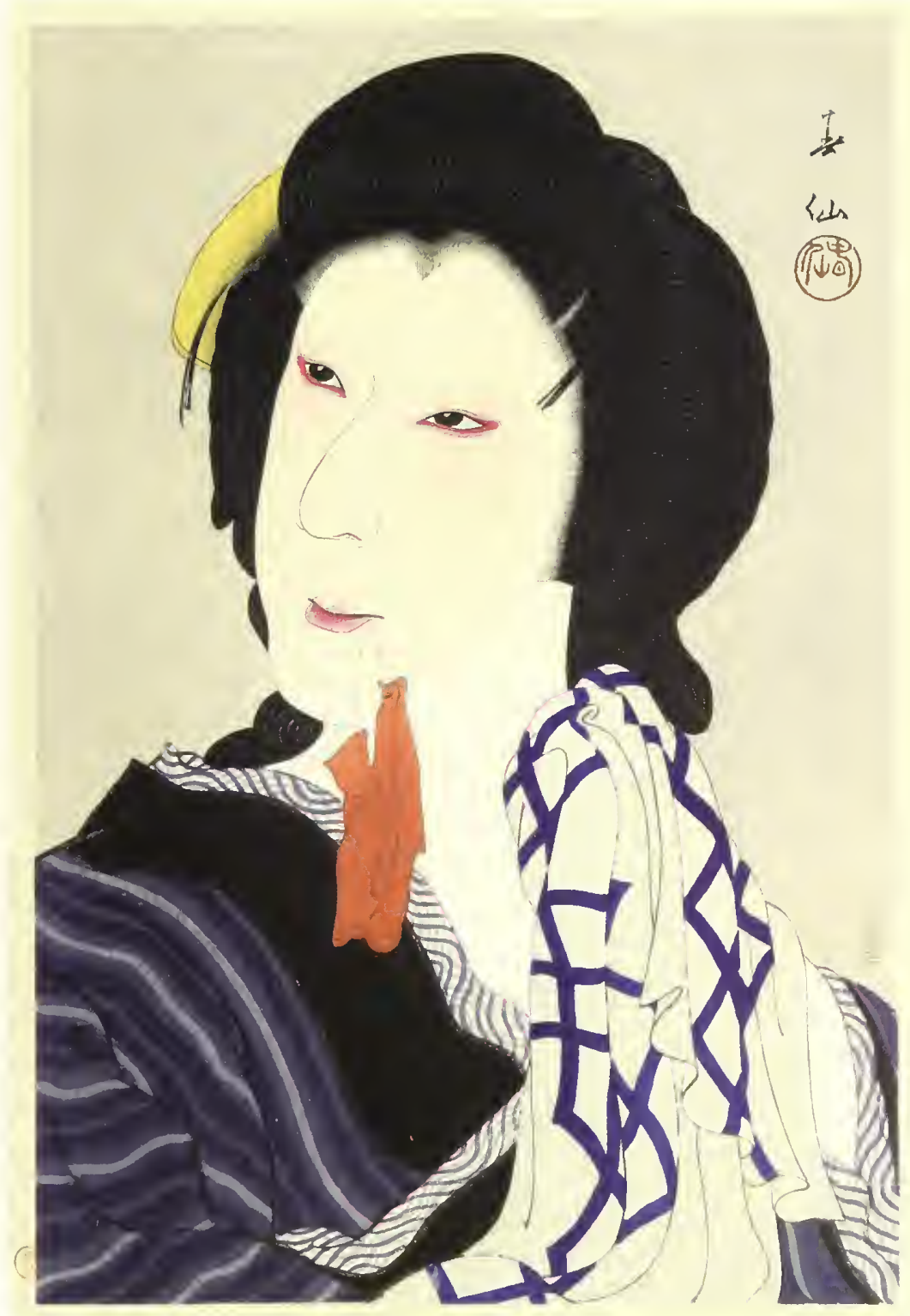

Shunsen's image of Otomi returning from the bath - with its suggestion of casual feminine sensuality - presents one of the most challenging and potentially rewarding exercises for a Kabuki actor: that of the onnagata female role played by a man. Ichikawa Kigan (Onimaru) V (1889-1978) was particularly renowned for his evocations of irresistible women. Shunsen deploys standard visual signals in this mildly erotic print - a few strands of hair out of place; the casual gesture of the nukabukuro (soap pouch) dangling from the bather's mouth; and the suggestion of lingering moisture from the bath. As in most Shunsen prints, pattern and textile frame the face and reinforce the emotional state presented - in this case, calculated disarray.

Based on a scene from the play Yowa nasake ukina no yokogushi ("Wounded Yosaburō"). 
YAMAMURA KŌKA (1886-1942)

Actor in a Chinese Opera

Japan, 1926

Woodblock print; ink and colour on paper

$37.8 \times 26 \mathrm{~cm}$

Arthur M. Sackler Gallery, Smithsonian Institution,

Washington D.C.; Robert O. Muller Collection

Inv. no. $\$ 2003.8 .3411$

Köka, whose name was virtually synonymous with the production of elegant images of actors, startles here with his choice of subject - a figure from Chinese opera. This print and a 1924 one of a Shanghai dance hall (seen in the "Beauty Personified" section, cat no. 31) indicate the artist's creative and resourceful departure from traditional themes to explore everyday Japanese life, impacted by a formidable presence on the Chinese mainland. At the outset of World War I the Europeans ceded the control of their East Asian colonies to the Japanese, whose ever-increasing commercial and military presence on the mainland provided a natural subject matter for domestic print consumption.

Based on a scene from the play Seichüden. 
The influence of the traditional Kabuki print on journalistic and other dramatic renderings

Woodblock prints enjoyed a temporary revival as propaganda images used to "report" and to gain support for Japan's two colonial wars in Manchuria - the Sino-Japanese War (1894-95) and the RussoJapanese War (1904-05). The best known means for depiccing narracive action were the composition and style formulas of pre-modern Kabuki prints which featured key dramatic moments from plays. Designers of prints featuring "true" images of battle scenes effectively borrowed from the Kabuki print conventions of character placement and exaggerated posturing of figures

Creators of prints that depicted Kabuki stage scenes had the most experience in showing narrative action frozen into a still image. Thus, when designers of war prints depicted battle scenes they took on a somewhat staged or artificial feeling. Because of their visual association with Kabuki prints, these war prints were said to easier for audiences to "read" than the still unfamiliar photograph format. Later as these same designers became more acquainted with European paintings and prints of warfare, those Western conventions were sometimes integrated into the print designs.

For example, an artist such as Tsukioka Yoshitoshi (1839-92) brought an exciting new look to woodblock print advertisements for current Kabuki plays by including Western perspectival rules rather than in the somewhat stiff, flat approximation of a tradicional Japanese theatre stage.
TSUKIOKA YOSHITOSHI (1839-1892)

Fujiwara no Yasumasa plays the flute by moonlight Japan, 1883

Woodblock print; ink and colour on paper $36 \times 71.9 \mathrm{~cm}$

Arthur M. Sackler Gallery, Smithsonian Institution, Washington D.C.; Robert O. Muller Collection Inv no. \$2003.8.3010a-c

Yoshitoshi recounts the story of the courtier Fujiwara no Yasumasa (958-1036), who is strolling on a desolate moor one chilly autumn night when a highwayman, in search of winter clothing, approaches him. Planning to ambush the courtier, the would-be robber is instead lulled by the seductive sounds of Yasumasa's flute and follows the nobleman to his residence, whereupon the ruffian is presented with a robe. The story sug. gests a recurring theme of court literature: the victory of culture over violence, of the scholar-courtier over the warrior. This legend was adapted for Kabuki and the triptych was produced to coincide with an 1883 staging. Yoshitoshi's late- $19^{\text {th }}$-century prints bear the overlay of the Kabuki stage but also anticipate the cinematographer's eye.

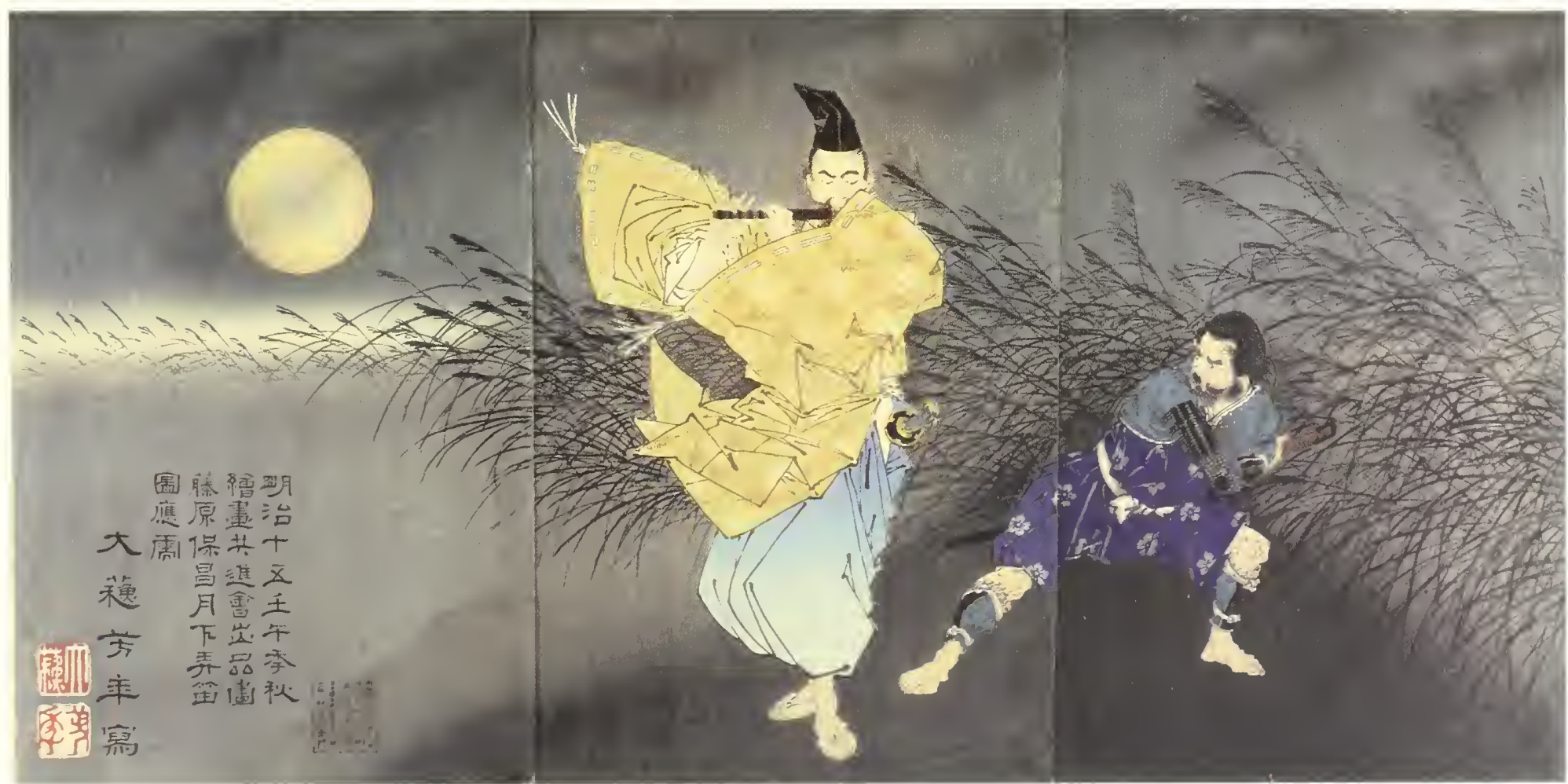


TSUKIOKA YOSHITOSHI (1839-1892)

Fight on roof of Hōryūkaku

Japan, 1885

Woodblock print; ink and colour on paper

$72.1 \times 24.1 \mathrm{~cm}$

Arthur M. Sackler Gallery, Smithsonian Institution,

Washington D.C.; Robert O. Muller Collection

Inv. no. $52003.8 .3005 a-b$

The moment of confrontation between warriors who prepare for a one-on-one battle on the steep roof of a castle tower is dramatically framed by the narrow format of this vertical diptych. The diagonal roofline of the Hōryūkaku tower of Koga Castle (in present-day lbaraki Prefecture, north of Tokyo) links the two valiants. Yoshitoshi a novel element - the distant clouds, which purportedly derive from similar renderings found in northern European copperplate engravings. The sudden flight of startled birds alleviates the tension of the warriors poised for a fateful battle, during which they will plummet from the rooftop into the Tone River below - and survive.

Based on a scene from the play Nansō satomi hakkenden ("The tale of eight dogs of the Satomi clan").
TSUKIOKA YOSHITOSHI (1839-1892)

Watanabe no Tsuna confronting Ibaraki

Japan, 1888

Woodblock print; ink and colour on paper

$72.6 \times 24.8 \mathrm{~cm}$

Arthur M. Sackler Gallery, Smithsonian Institution,

Washington D.C.; Robert O. Muller Collection

Inv. no. $\$ 2003.8 .3004 a-b$

Yoshitoshi was the master of the compositionally dynamic vertical format, as this print demonstrates. The scene refers to the legendary encounter between warrior Watanabe no Tsuna and a demon called Ibaraki at the Rashōmon Gate, guarding the southern border of Kyoto. This $10^{\text {th }}$-century episode was the subject of the Kabuki dance drama lbaraki. Yoshitoshi was frequently commissioned to publicize current theatre events. Here, he veers from the traditional horizontal format that mimicked the theatre stage and captures the dynamism and claustrophobia of the moment, as the demon descends on the warrior.

Based on a scene from the play lbaraki.

Attributed to TOYOHARA KUNICHIKA (1835-1900)

The infantryman Sawada Jushichi climbing the Genbu Gate at Pyongyang

Japan, 1894

Woodblock print; ink and colour on paper

$109 \times 24.1 \mathrm{~cm}$

Arthur M. Sackler Gallery, Smithsonian Institution, Washington D.C.; Robert O. Muller Collection

Inv. no. \$2003.8.2762

In the Meiji era, Japan fought two colonial wars, both involving the control of resource-rich Manchuria - the Sino-Japanese War (1894-95) and the Russo-Japanese War (1904-05). The wars provided a brief but major source of work for print artisans whose golden age had passed. These highly contrived works were, in effect, propaganda, allowed by government censors to precede the dissemination of photographs of battles and battle sites. Here, in a scene from the Sino-Japanese War, a heroic infantryman under enemy fire scales the stone wall of Genbu Gate, in Pyongyang, Korea, behind which some fourteen thousand Chinese troops are stationed. Compositionally, such depictions of war scenes relied heavily on the conventions of Kabuki theatre. In fact, this and other notable war episodes were adapted to Kabuki drama. 

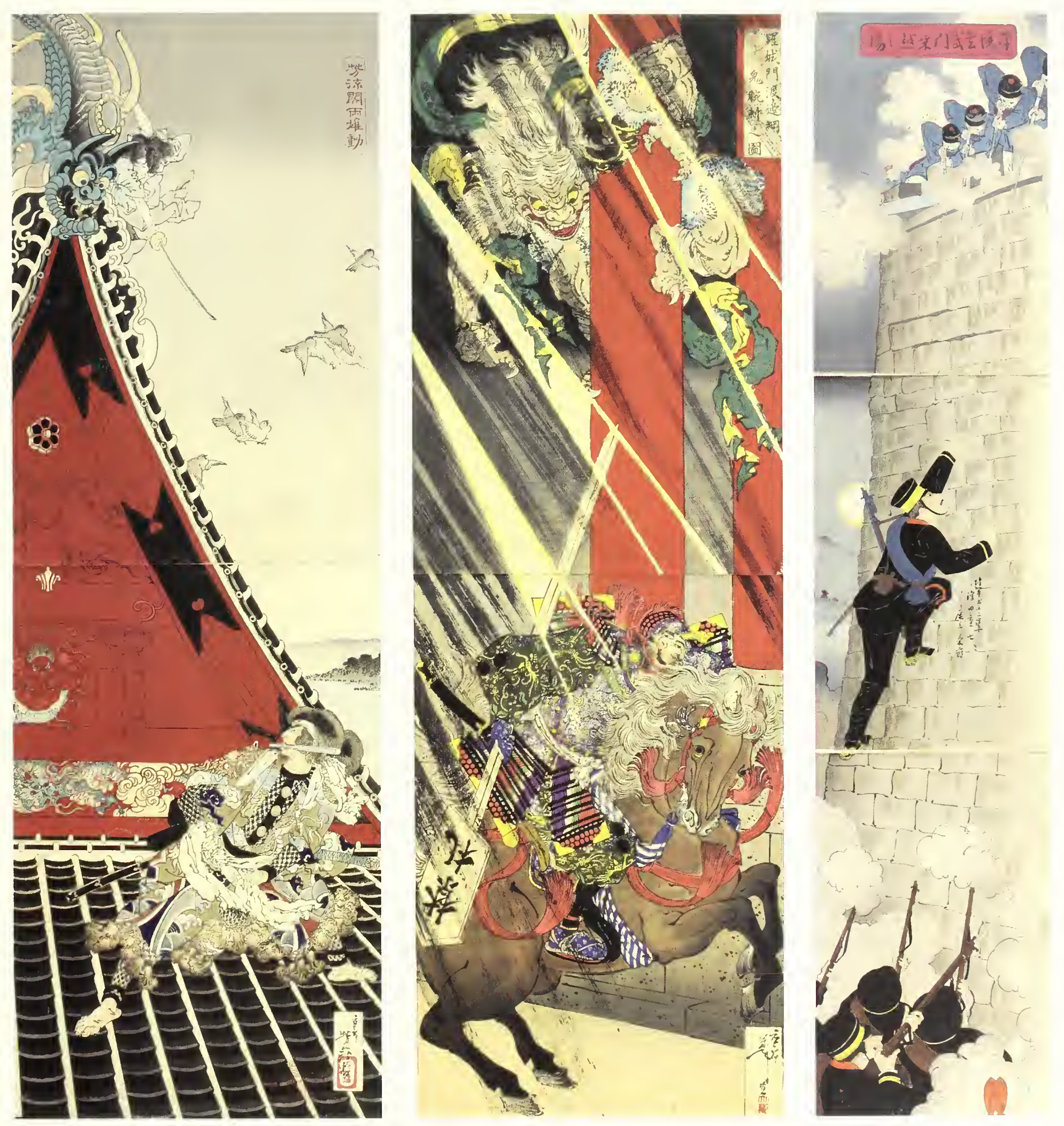
TAGUCHI BEISAKU (1864-1903)

Reconnaissance on an enemy base in Manchuria

Japan, 1895

Woodblock print; ink and colour on paper

$35.6 \times 71.1 \mathrm{~cm}$

Arthur M. Sackler Gallery, Smithsonian Institution,

Washington D.C.; Robert O. Muller Collection

Inv. no. S2003.8.52a-c

The harsh climate of Manchuria, the scene of much of the military action of the Sino-Japanese War (1894-95), was depicted in a number of prints. Here, Beisaku leaves selected sections of the original white paper blank to create the sensation of driving snow. As in many other prints of this war, the subject is the personal heroism of a scout and his aide, reconnoitring a new position. Riding gear and weapons provide the briefest points of colour accents and focus for this sophisticated study in grey and white.

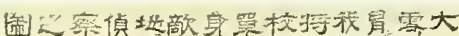

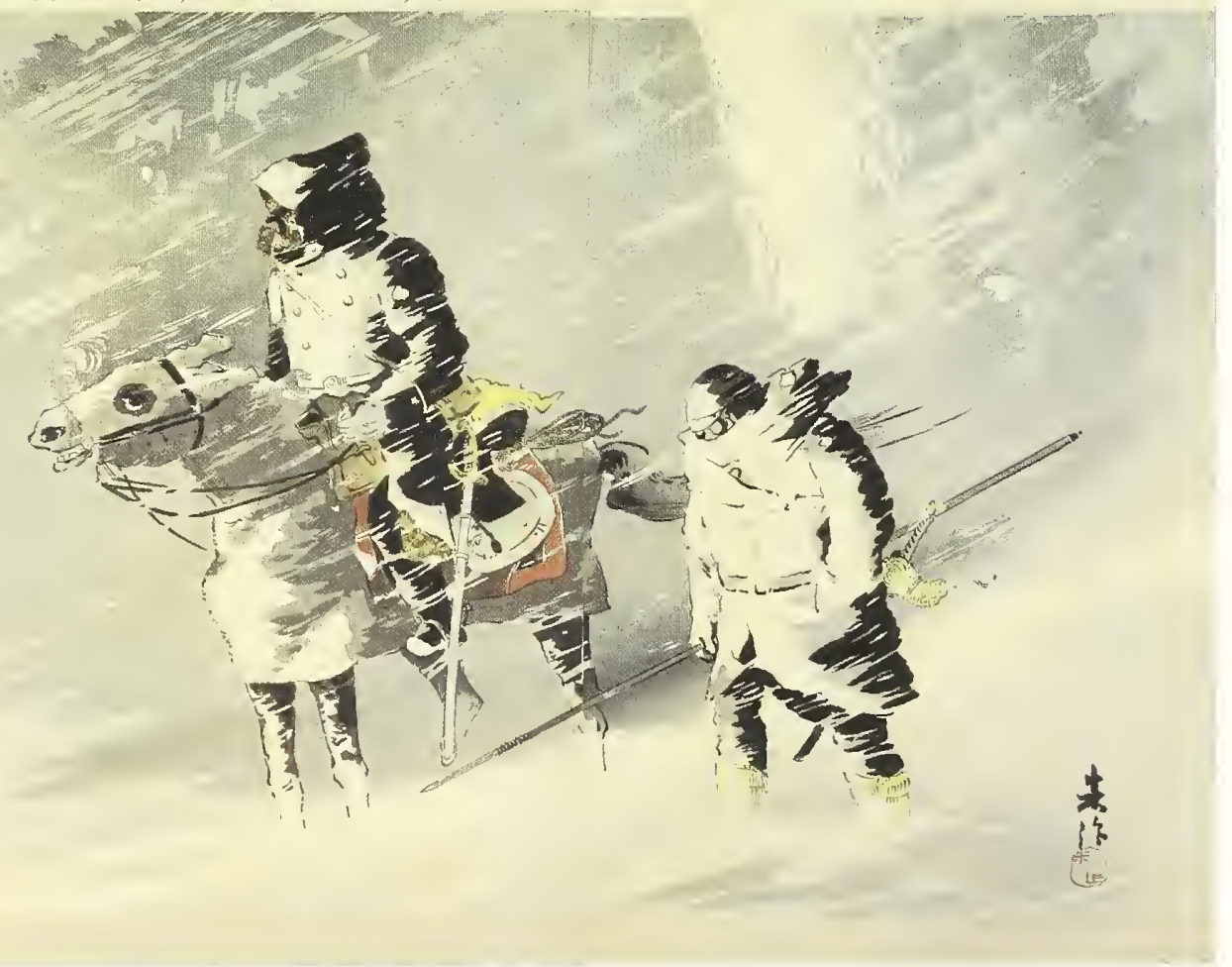




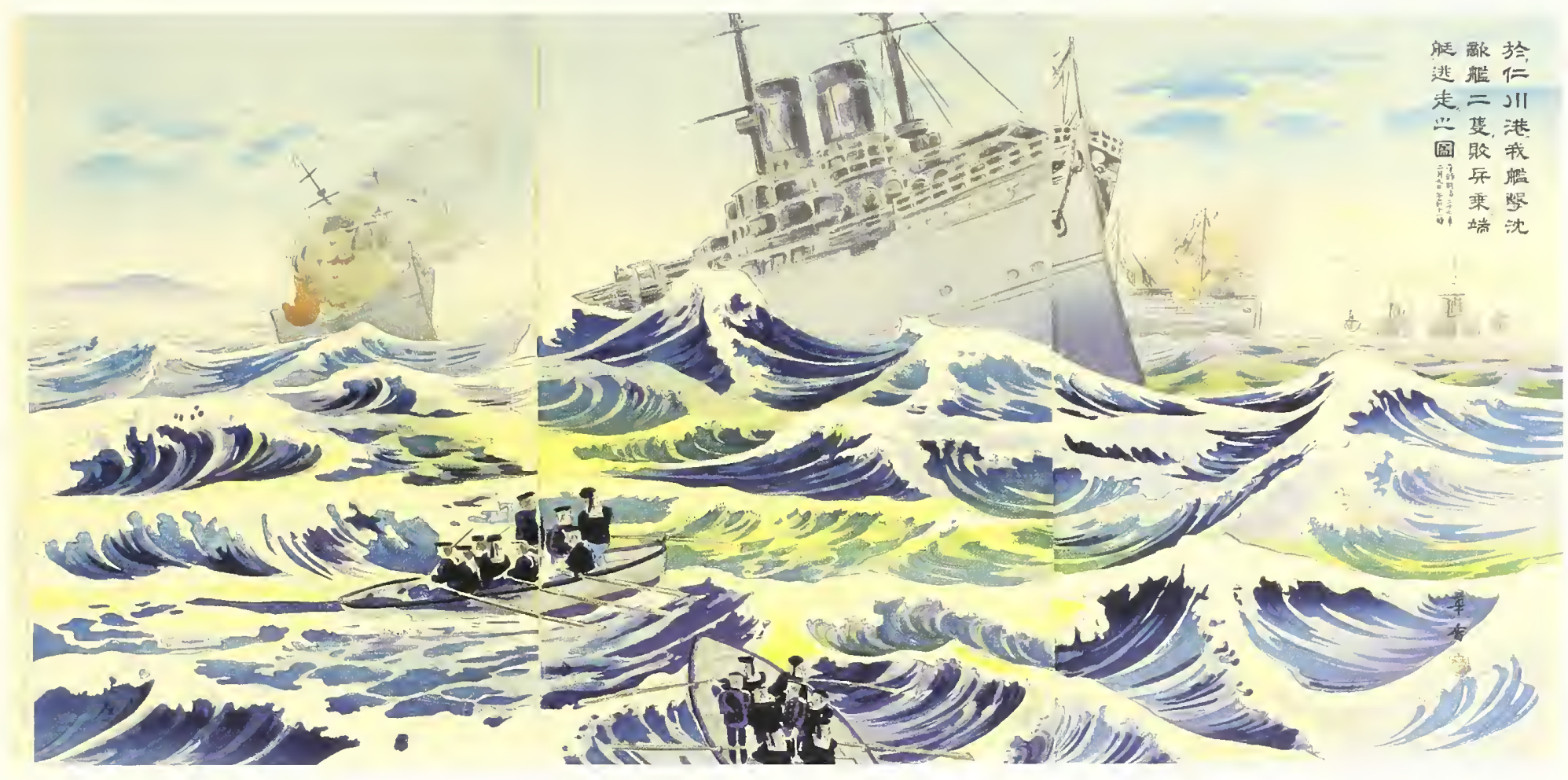

TSUJI KAKŌ (1870-1931)

Destruction of two Russian battleships

Japan, 1904

Woodblock print; ink and colour on paper

$35 \times 69.3 \mathrm{~cm}$

Arthur M. Sackler Gallery, Smithsonian Institution, Washington D.C.; Robert O. Muller Collection

Inv. no. $52003.8 .2787 \mathrm{a}-\mathrm{c}$

In February 1904 the seizure of Inchon, the Korean port just to the west of Seoul, and the attack and blockade of Port Arthur, on the Manchurian coast, were Japan's closely coordinated surprise attacks on Russian-held Manchuria and launched the Russo-Japanese War (1904-05), a struggle for colonial supremacy in northeast Asia. Although the Port Arthur foray was more famous, Inchon was the greater tactical achievement, because of the naval skills required to navigate the treacherous currents of the deep water harbour. Numerous painters found employment opportunities as print designers during the Russo-Japanese War and translated their unique painting styles into the print medium. Tsuji Kakō, a master of wave and water renderings, applies his forte in the depiction of the perils of Inchon Harbour. Indeed, water and its importance in the battle are the real subject of the print. 
BEAUTY PERSONIFIED 


\section{The vast majority of female images in pre-modern Japanese prints and paint-}

ings take as their subject women of the pleasure quarters. In a society that prized the enigmatic, portraiture did not have a strong artistic tradition. The world of the brothel provided access to unguarded moments wherein artists could observe an unfettered range of female moods. Whether or not they can be truly described as portraits, these pre-modern studies of these beauties explored, with varying degrees of skill, the depiction of a somewhat restricted range of emotions - wistful longing, crafty plotting, coyness, resignation. Revivalists such as Hashiguchi Goyō (1880-1921) and Itó Shinsui (1898-1972) maintained an interest in the traditional subject matter, thereby preserving that perspective well into the $20^{\text {th }}$ century. Given these origins, artistic approaches to depicting women of the modern era remained, at their foundation, unavoidably erotic. Thus, the $20^{\text {th }}$-century audience expected an inevitable, mild eroticism in images of women.

The nostalgic agenda of Shin-hanga artists was largely unaffected by real social changes. In the $20^{\text {th }}$ century women joined the urban work force in vast numbers and, particularly in the 1910s and 1920s, enjoyed an unprecedented degree of social freedom. Artists who chronicled this new creature often found it difficult to depict her without alluding to her compromised moral foundation. 


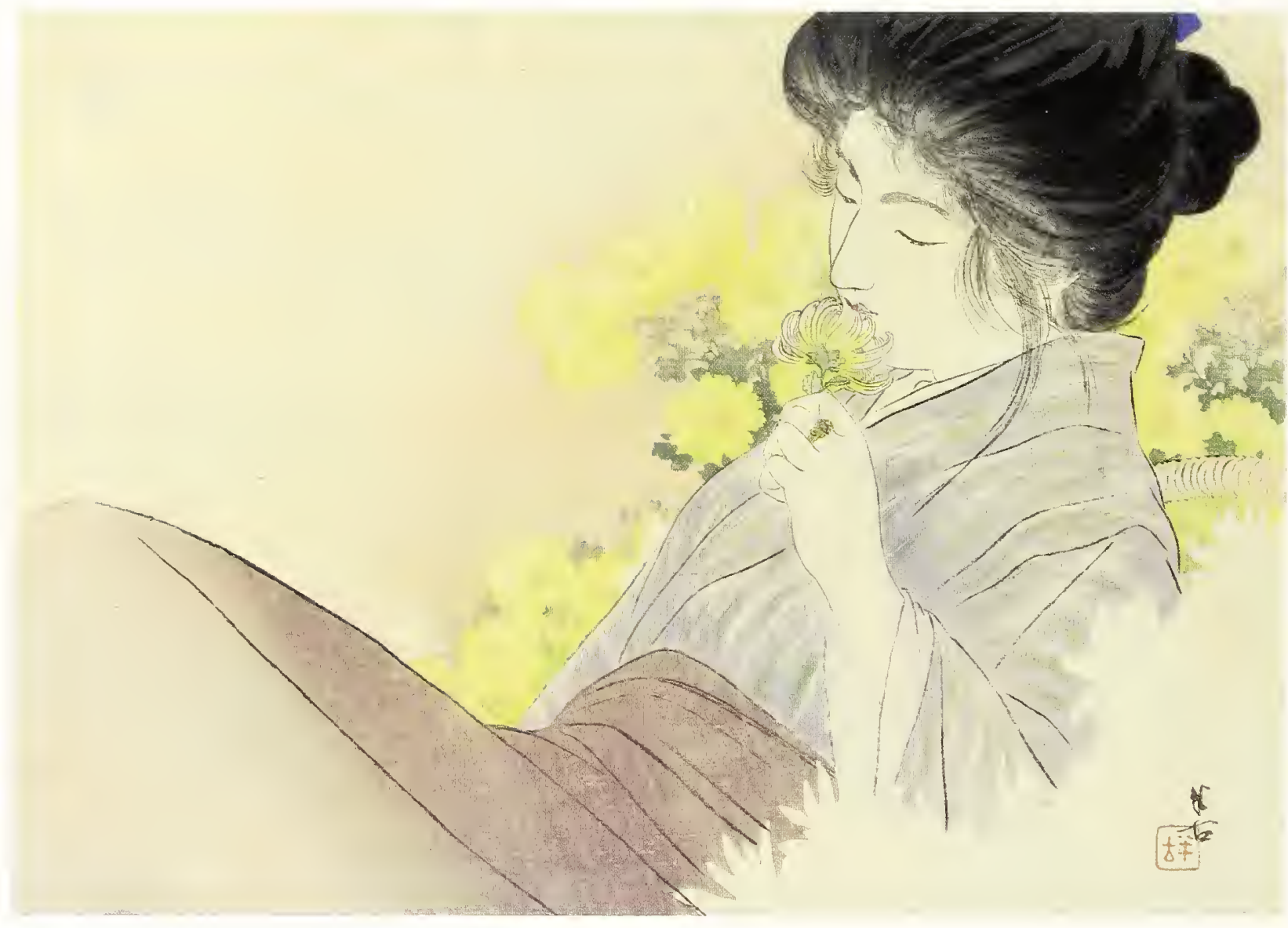

KAJITA HANKO (1870-1917)

The fragrance of chrysanthemums

Japan, 1905

Woodblock print; ink and colour on paper

$22.5 \times 31 \mathrm{~cm}$

Washington D. C., Arthur M. Sackler Gallery, Robert O. Muller Collection

Inv. no. $\$ 2003.8 .432$

This image introduced an instalment of a serialized novel Shiragiku ("White chrysanthemum") by Ōgoshi Dairoku, published in the literary journal Bungei Kurabu. In a story line that rivals the complexity of the densest Kabuki play, the young woman seen here learns while recuperating at a spa that the blind masseuse who attends her is her long-lost father. This striking beauty, clearly a woman of social standing and propriety, is nevertheless depicted with the lightly erotic sentiment that typically infused the prints of an earlier age.
TSUKIOKA YOSHITOSHI (1839-1892)

\section{The rescue of Oshichi}

Japan, 1885

Woodblock print; ink and colour on paper

$71.2 \times 24.4 \mathrm{~cm}$

Arthur M. Sackler Gallery, Smithsonian Institution, Washington D.C.; Robert O. Muller Collection

Inv. no. $\$ 2003.8 .3008 a-b$

In 1682 sixteen-year-old Oshichi fell in love with a man who assisted her during a fire evacuation. Later, desperate to reunite with him, she set her family home on fire. The actual event inspired various fictionalized versions, among them an 1856 Kabuki play. In this diptych, Yoshitoshi presents Oshichi escaping from her own arsenous act. Fire brigades, represented by their standards, cluster at the base of the ladder and await Oshichi's descent. Her hope, perhaps suggested by the distant focus of her glance, is that her paramour will appear. Her placement on the ladder, with flames approaching, anticipates what would be her tragic punishment - being burned at the stake. 


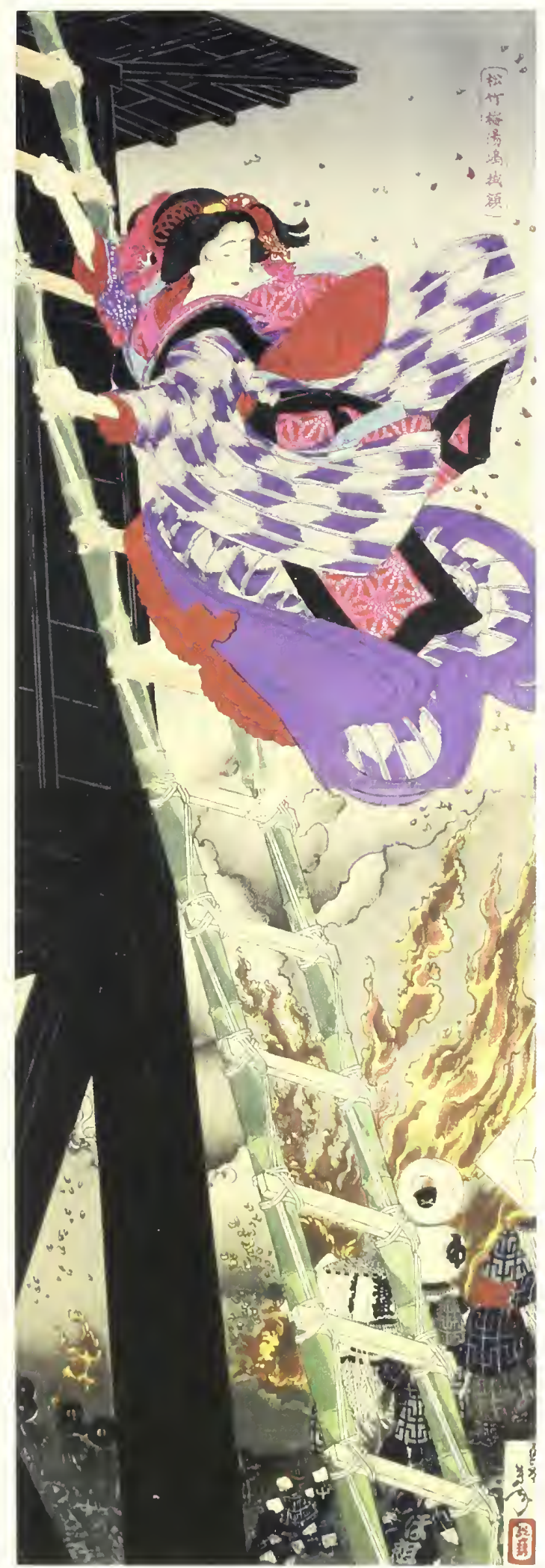

TSUKIOKA YOSHITOSHI (1839-1892)

Kiyohime changing into a serpent at the Hidaka River from the series "Thirty-six ghosts" (Shingata sanjürokkaisen) Japan, 1890

Woodblock print; ink and colour on paper $34 \times 23 \mathrm{~cm}$; Overall: $38.5 \times 27 \mathrm{~cm}$

Arthur M. Sackler Gallery, Smithsonian Institution, Washington D.C.; Robert O. Muller Collection Inv. no. 52003.8 .3070

Yoshitoshi favored the depiction of obsessed or haunted women. Here, he recalls the ancient tale of the beauty Kiyohime and story recounts the obsessive and her unrequited love for a monk, Anchin, whose vows call for celibacy. Fleeing from her, Anchin seeks refuge in a temple on the far side of the Hidaka River. When Kiyohime pursues him, she is thwarted by the river's flood-swollen waters. She transforms herself into a serpent, traverses the river, and emerges on the other bank. In suggesting Kiyohime's bestial posture and the scale-like patterns of her garments Yoshitoshi creates a subtle, almost ambiguous moment in a continuum between serpent and human.

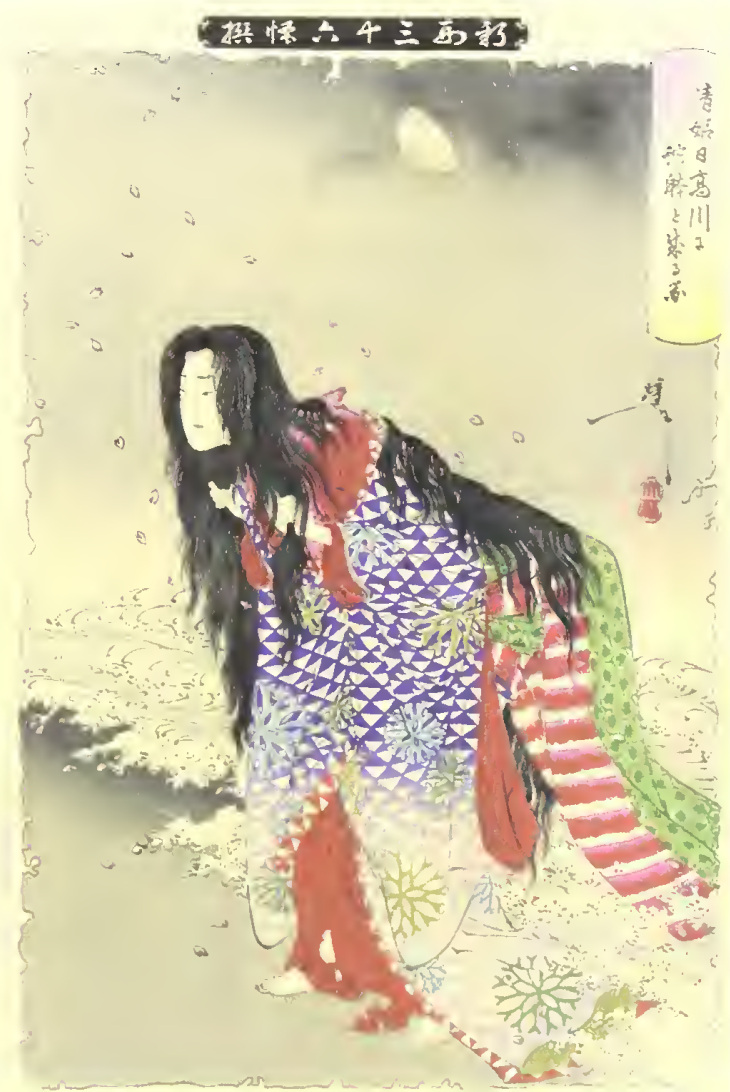


KOBAYASHI KIYOCHIKA (1847-1915)

Three geisha: Kayo of Kyoto, Hitotsuru of Osaka, and Kokichi of Tokyo

Japan, ca. 1878

Woodblock print; ink and colour on paper

$35.2 \times 24.4 \mathrm{~cm}$; Overall: $38.3 \times 30 \mathrm{~cm}$

Arthur M. Sackler Gallery, Smithsonian Institution,

Washington D.C.; Robert O. Muller Collection

Inv. no. S2003.8.1157

Kiyochika was a late- $19^{\text {th }}$-century pioneer of woodblock print innovation. He was also trained as a photographer. In his prints he often sought to mimic but better the effects of the photograph, a medium then experiencing great popularity.

At first glance this surreal image appears to be the multiple exposures of a daguerreotype portrait. The black-and-white tones of the portrait, the oval frame, and the dark background all suggest the influence of photography. Kiyochika conflates the portraits of the three geishas into one, overlapping the facial features of each figure. The artist's montage alludes to the centuries-old conceit of depicting in paintings three beauties representing the cities of Kyoto, Osaka, and Tokyo. The haiku on the poem card to the right reads, "Oh, to see the moon and snow together in the mountain of blossoms."
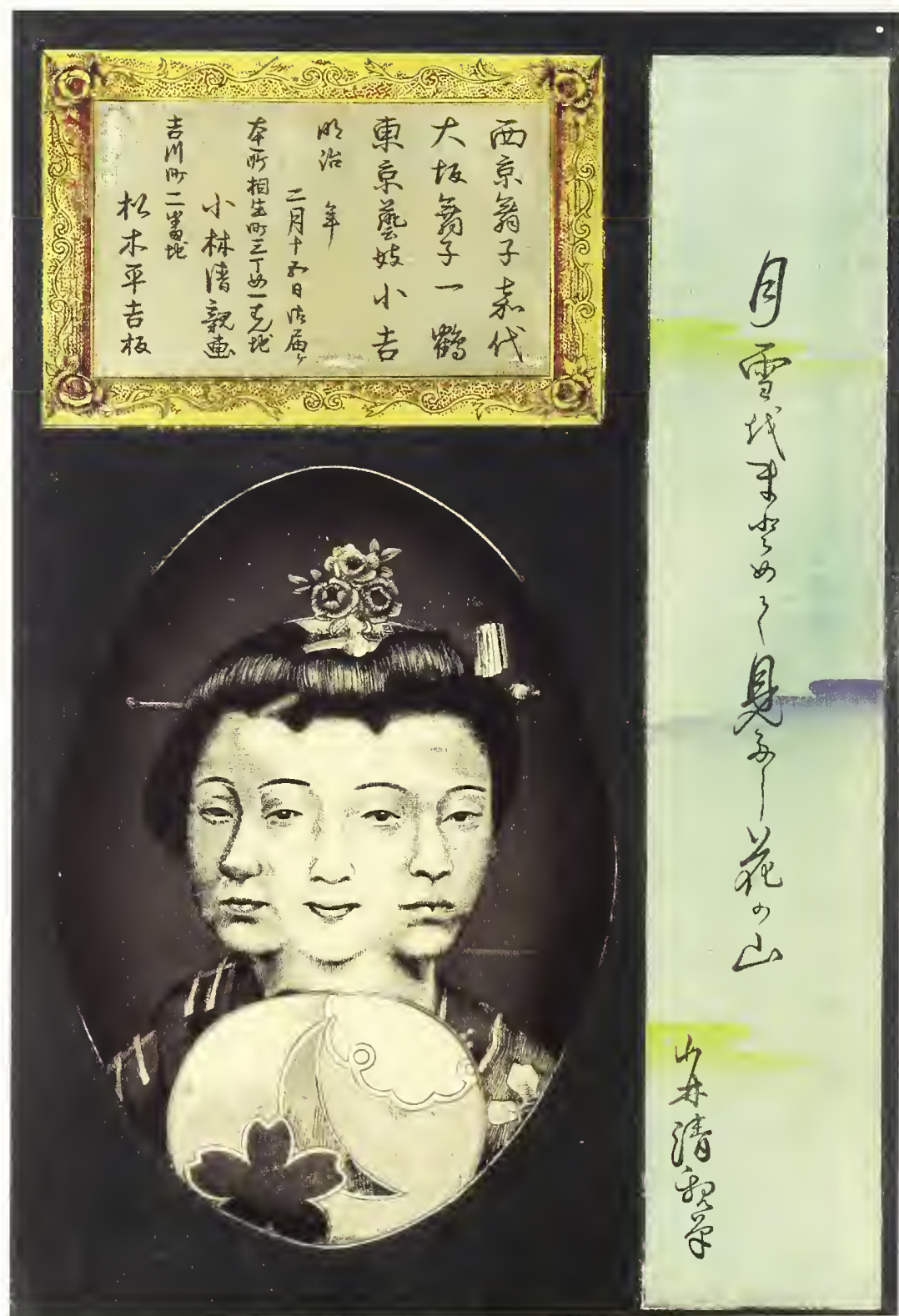


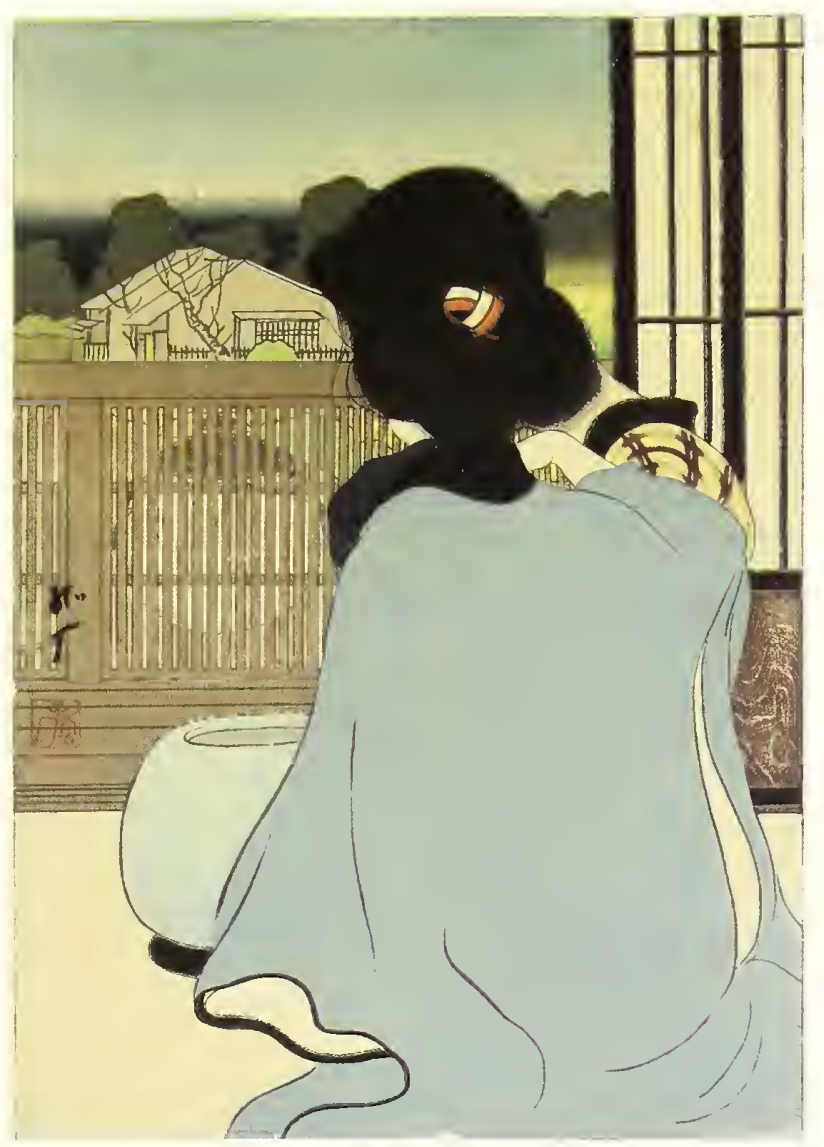

TOBARI KOGAN (1882-1927)

Guests at a hot spring inn Japan, 1921

Woodblock print; ink and colour on paper

$45.7 \times 32.2 \mathrm{~cm}$

Arthur M. Sackler Gallery, Smithsonian Institution, Washington D.C.; Robert O. Muller Collection

Inv. no. 52003.8 .2507

Kogan studied at the Art Student's League in New York and there became aware of the Western ideal of the artist as an autonomous creator. He found this appealing notion at odds with the traditional "quartet" of the Japanese print industry guild - designer, carver, printer, and publisher. Ultimately, Kogan became an organizing force for adherents of the Sosakuhanga or "creative print" style. Works created by practitioners of this divergent group tended to have an amateurish flavour because the artist handled all aspects of production. This print by Kogan, while deceptively simple in concept, is a technically masterful mélange of forms and patterns.

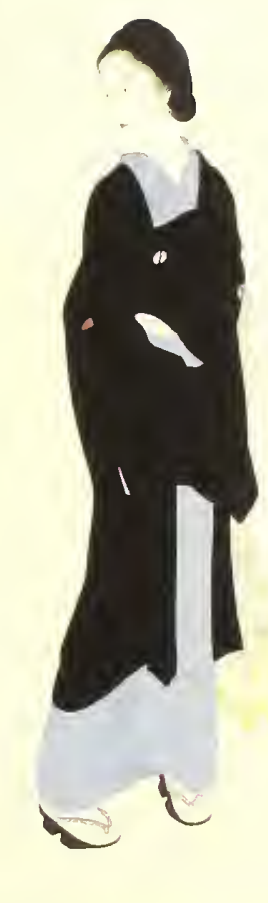

KABURAGI KIYOKATA (1878-1972)

Tsukiji Akashi-chō

Japan, 1928

Woodblock print; ink and colour on paper $59 \times 34.8 \mathrm{~cm}$

Arthur M. Sackler Gallery, Smithsonian Institution, Washington D.C.; Robert O. Muller Collection Inv. no. $\$ 2003.8396$

This print is modelled on an award-winning painting that Kiyokata submitted to the Teiten, the Imperial Academy of Fine Arts Exhibition, in 1927. Its subsequent reproduction as a print testifies to the universal acclaim that the painting received.

The young woman portrayed here, who was apparently Kiyokata's student, Egi Maseko, strolls through the Tsukiji Akashi-chō neighbourhood of eastern Tokyo, near Tokyo Bay, as the ships in the distance indicate. Kiyokata was famous for the elegant, lithe, and steely beauties in his paintings and prints. Maseko seems to clutch at her outer garment, as if to ward off the earlymorning chill. 
KOBAYAKAWA KIYOSHI (1897-1948)

\section{Tipsy}

From the series "Modern styles of women" (Kindai jiseshō no uchi yon)

Japan, 1930

Woodblock print; ink and colour on paper

$45.7 \times 29.6 \mathrm{~cm}$

Arthur M. Sackler Gallery, Smithsonian Institution,

Washington D.C.; Robert O. Muller Collection

Inv no. 52003.8 .1092

Kiyoshi's series, Modern styles of women, celebrated the phenomenon of the modan gäru (modern girl). The name itself is one of thousands of examples of Japan's wholesale absorption of foreign vocabulary, appropriately modified in pronunciation. Known by the shorthand moga, the term was applied to women who embraced current trends and fashions, usually Western, entered a new labour force, and were generally thought of as being far more assertive than the "traditional" Japanese woman. Kiyoshi's image of such a modern woman fulfils every expectation of the type. From the accoutrements of indulgence - cigarettes and cocktails consumed in public - to the direct gaze at the viewer, there is a complete abandonment of the demure or feigned coyness often seen in this genre.

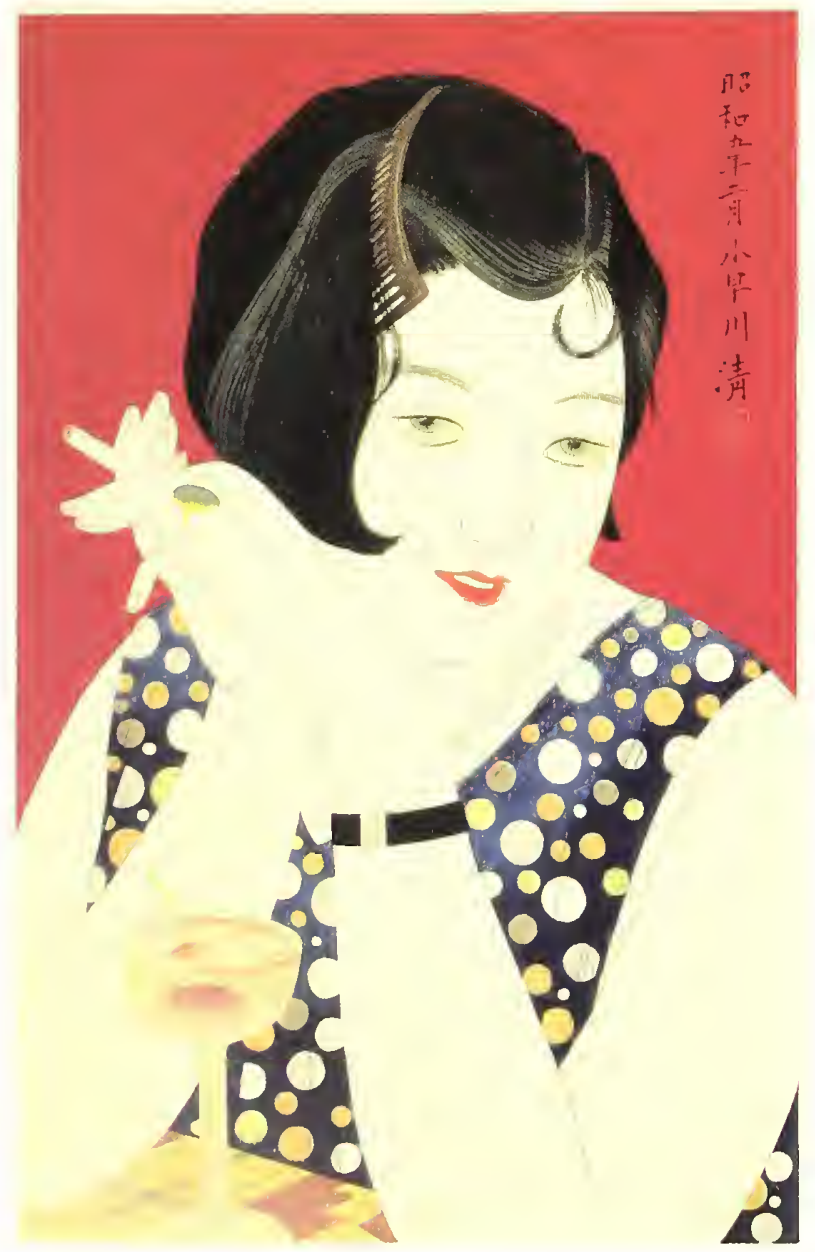

YAMAMURA KŌKA (TOYONARI) (1886-1942) A dance hall in Shanghai

Japan, 1924

Woodblock print; ink and colour on paper

$42 \times 29.3 \mathrm{~cm}$; Overall: $44 \times 30.8 \mathrm{~cm}$

Arthur M. Sackler Gallery, Smithsonian Institution,

Washington D.C.; Robert O. Muller Collection

Inv. no. $\$ 2003.83419$

Best known for his actor prints, Kōka ventured into the more exotic world of Shanghai in the 1920s. It was a thoroughly international city to which many Japanese traveled or, indeed, relocated as residents commissioned to oversee business and government ventures. Köka depicts modern women, out on the town, who are geographically removed from what social constraints remained in Japan of the 1920s. While the subjects are probably Asian, their precise nationality is unclear - Chinese or Japanese? Visitors or residents?

TAKAHASHI SHŌTEI (1870-1945)

Woman at a mirror

Japan, ca. 1927

Woodblock print; ink and colour on paper

$41.2 \times 28.9 \mathrm{~cm}$

Arthur M. Sackler Gallery, Smithsonian Institution, Washington D.C.; Robert O. Muller Collection

Inv. no. S2003.8.2294

Shōtei, like a number of his contemporaries, experiments here with a hybrid image. The woman's body and her comportment are direct quotations of the late- $18^{\text {th }}$-century style for depicting female nudity and as such convey a sense of stability and permanence. Adorning the top of this body, however, is a truly au courant hairstyle. As a whole, the print exudes an awkward charm and, perhaps as the artist's intention, a conscious melding of past and present. All of the printing blocks for works created by Shōtei from 1929 to 1932 were destroyed in the World War II bombings of Tokyo. This fact accounts for the rarity of his prints. 

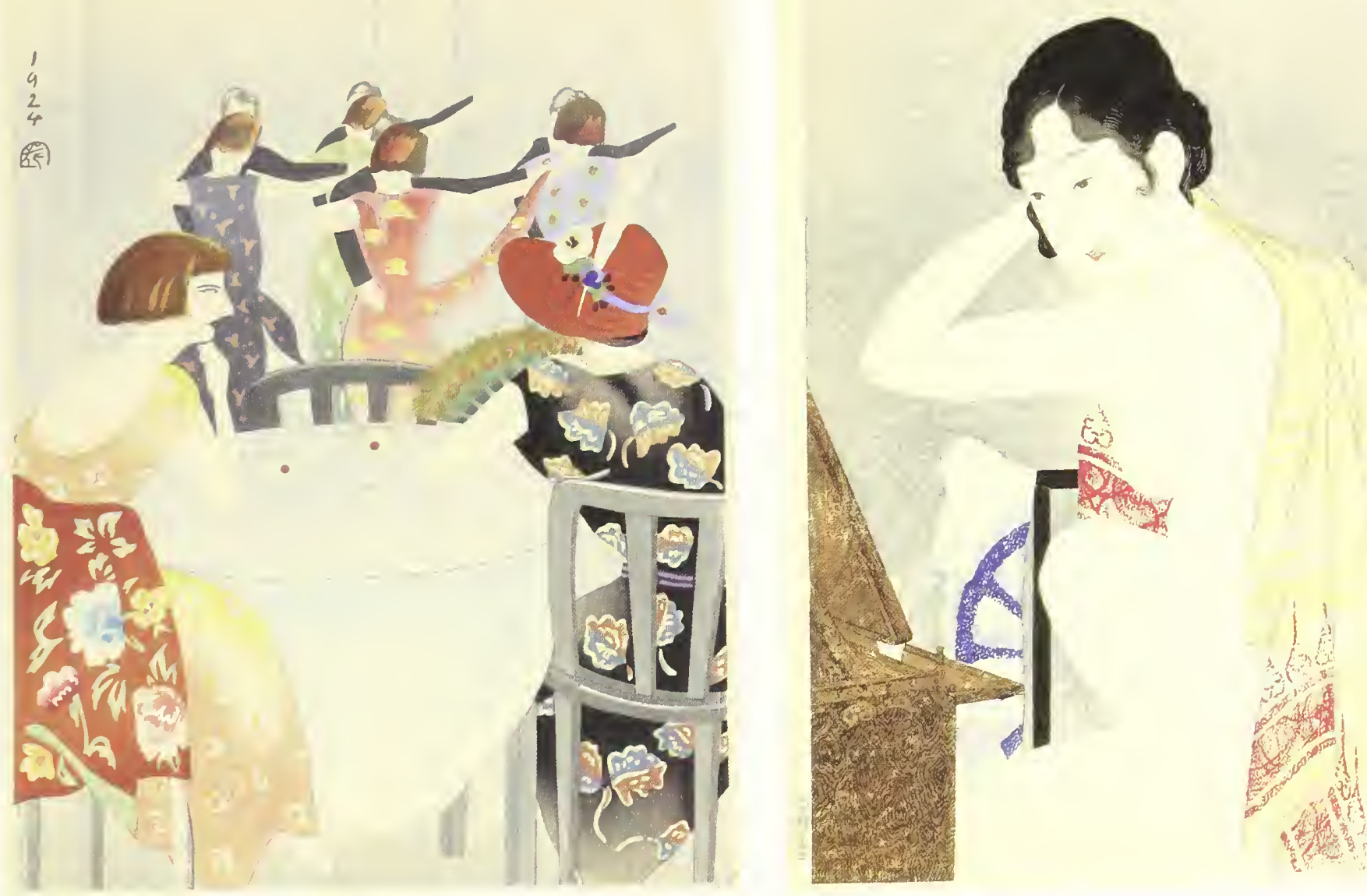


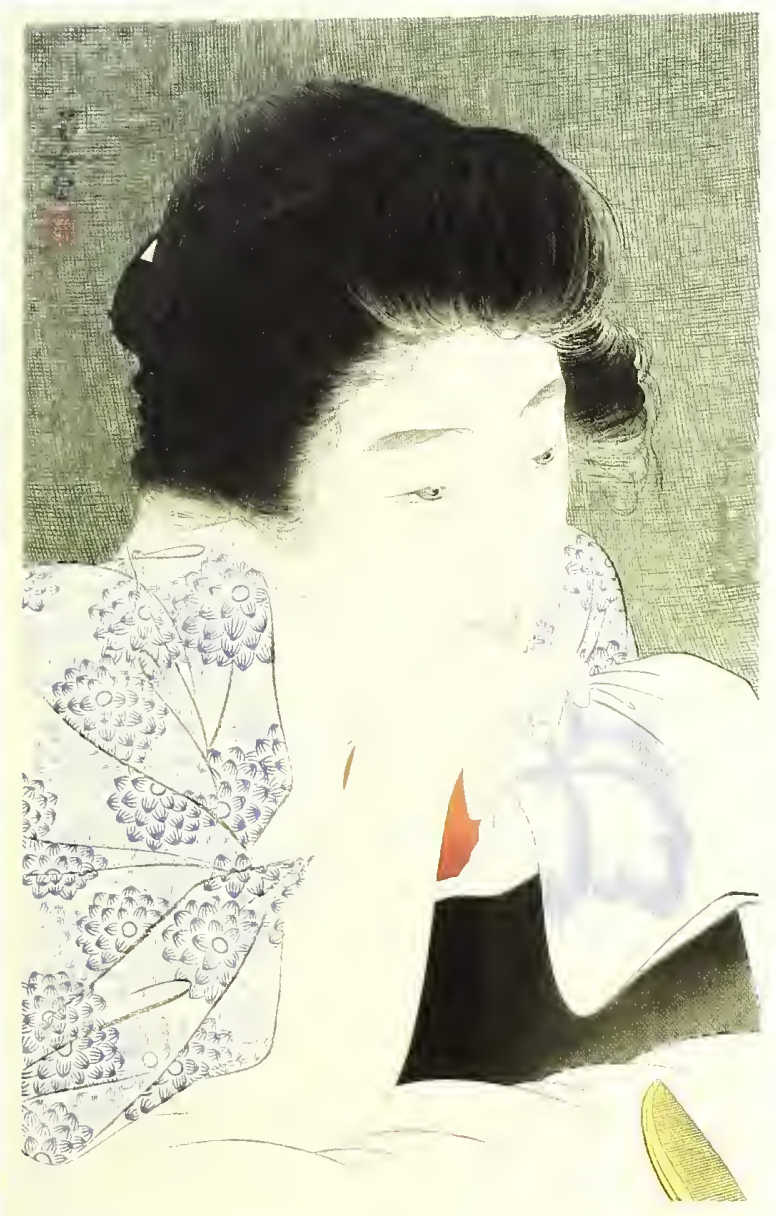

TORII KOTONDO (1900-1976)

\section{Morning hair}

Japan, 1932

Woodblock print; ink and colour on paper

$43 \times 27.2 \mathrm{~cm}$

Arthur M. Sackler Gallery, Smithsonian Institution, Washington D.C.; Robert O. Muller Collection Inv. no. $\$ 2003.8 .2550$

\section{TORII KOTONDO (1900-1976)}

\section{Keyblock print for 'Morning hair'}

Japan, 1932

Woodblock print; ink and colour on paper $38.2 \times 25.8 \mathrm{~cm}$

Arthur M. Sackler Gallery, Smithsonian Institution, Washington D.C.; Robert O. Muller Collection Inv. no. \$2003.8.2551

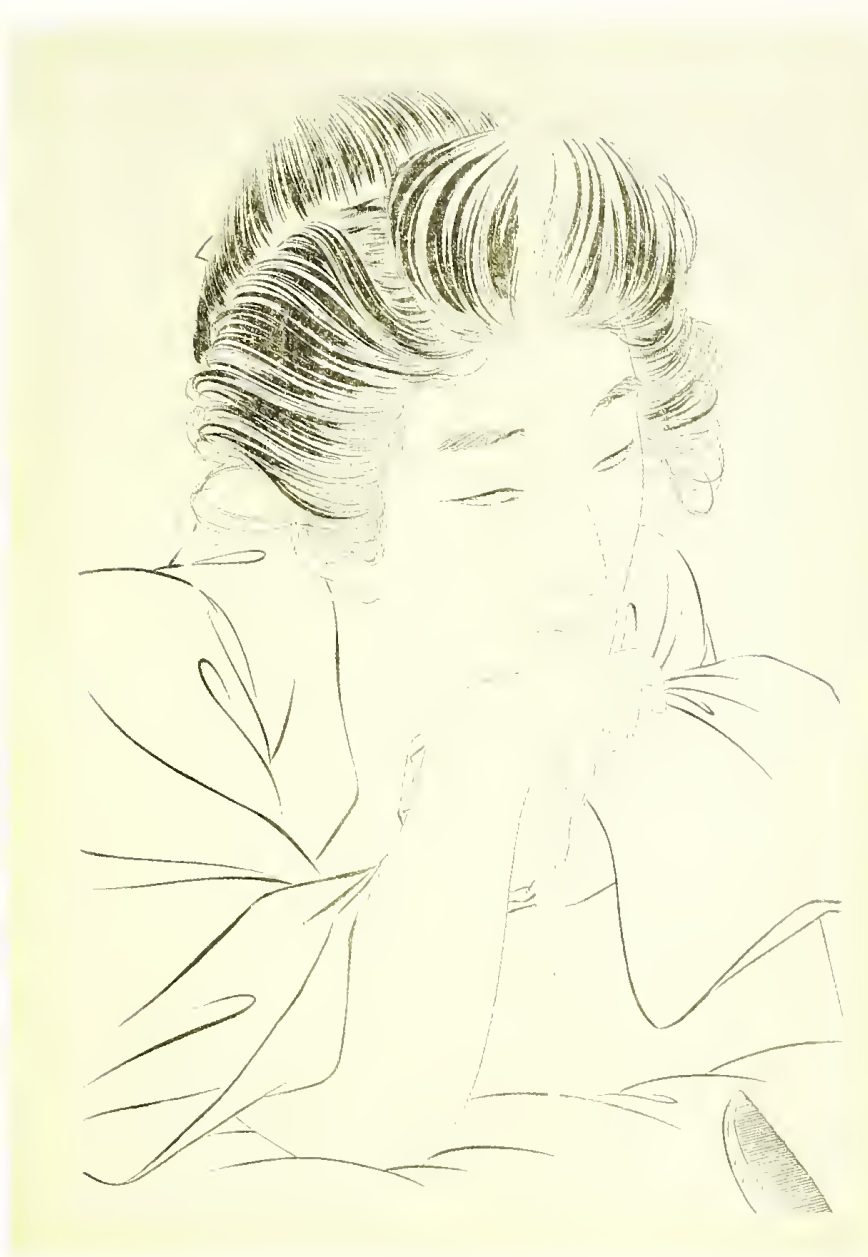

A woman, still in her bedclothes and resting on her pillow, seems lost in reverie - perhaps contemplating the previous night's encounter. The backdrop of green mosquito netting situates this scene on a summer's morning. Government authorities interpreted Kotondo's print as salacious and, of the one hundred impressions produced, confiscated thirty that had not yet been sold. In this instance the artist worked with a publisher named Ikeda typically issued prints in limited editions of one hundred that were prized for their high quality.

The keyblock provides the essential outlines, carved in relief, and serves as the basis for all other woodblocks that add colour and shading to the final image. The deliberately incised line that runs down the middle of this design rendered the block useless. Presumably this was the publisher's way of creating exclusivity through a limited edition, but the censorship of the print may well have contributed to the motivation. 


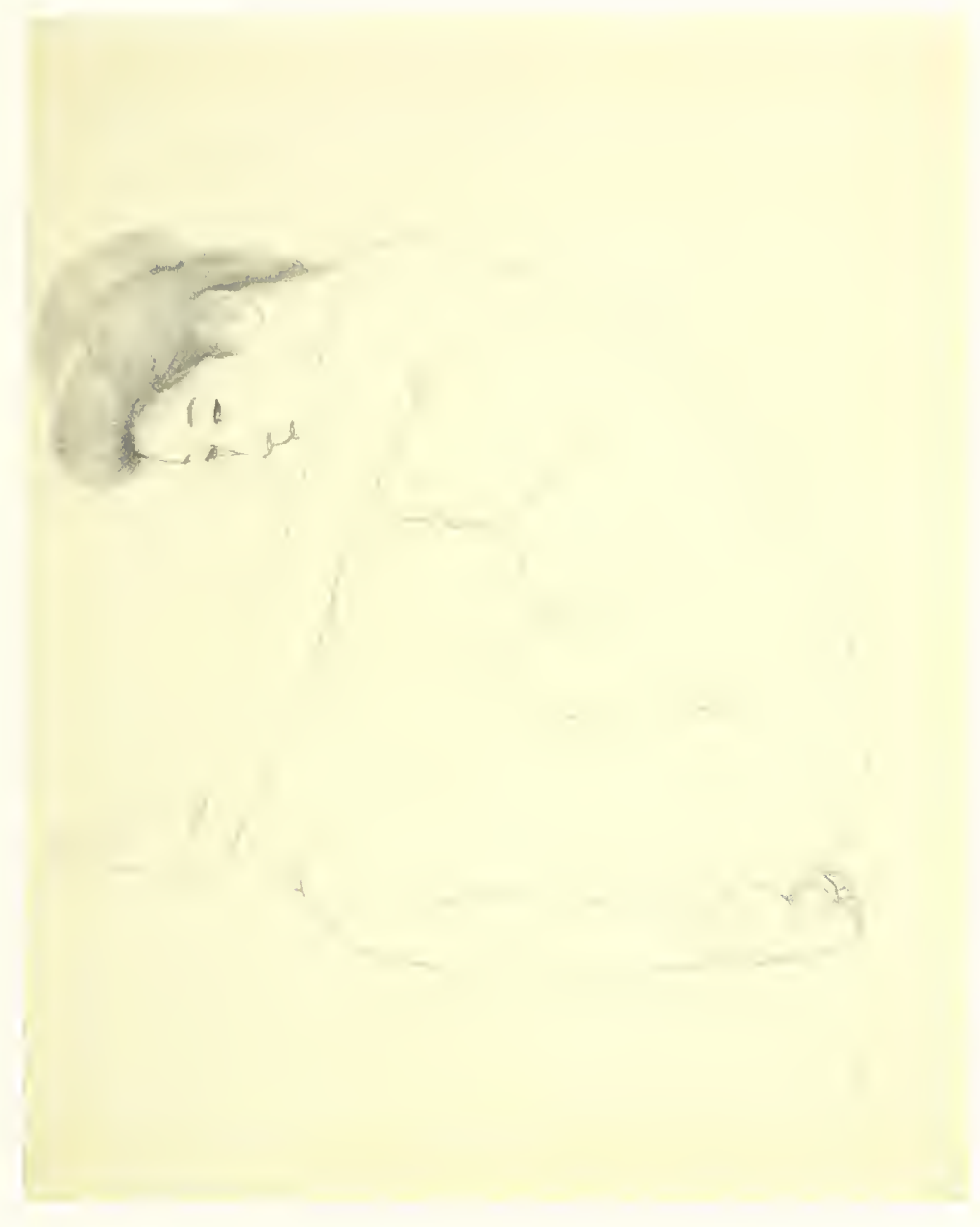

HASHIGUCHI GOYŌ (1880-1921)

Drawing

Japan, ca. 1920

Pencil on paper

$47.4 \times 37.8 \mathrm{~cm}$

Arthur M. Sackler Gallery, Smithsonian Institution,

Washington D.C.; Robert O. Muller Collection

Inv. no. \$2003.8.103

In contrast to his very limited production of completed woodblock prints, Goyō executed numerous pencil drawings, mostly of women and many extant. His reliance on sketches as foundational to his other work stemmed from his formal training in Western-style painting at the Tokyo Art School. The drawings, regardless of how they were ultimately transformed into prints, clearly indicate Goyō's intentions to express with clarity in composition and accuracy in draughtsmanship a sense of the corporeality.

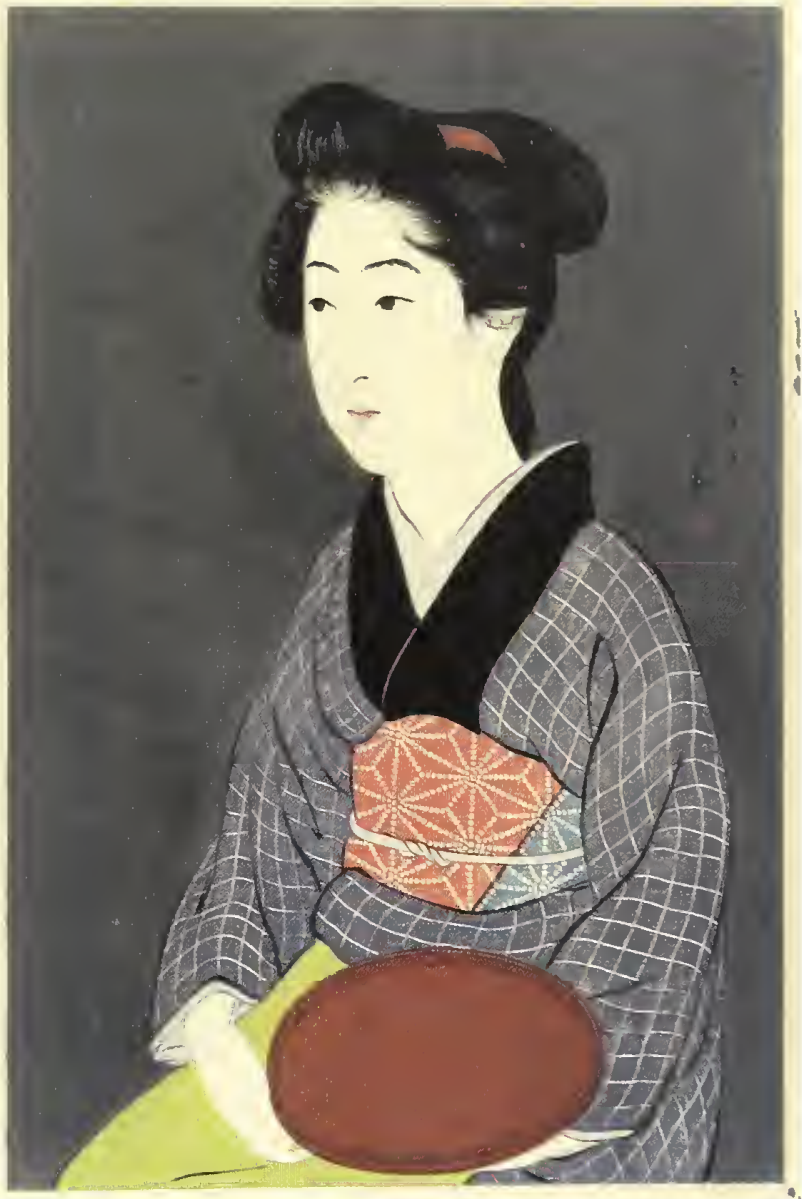

HASHIGUCHI GOYÕ (1880-1921)

Woman with a tray

Japan, 1920

Woodblock print; ink and colour on paper

$40.2 \times 27.2 \mathrm{~cm}$

Arthur M. Sackler Gallery, Smithsonian Institution,

Washington D.C.; Robert O. Muller Collection

Inv. no. \$2003.8.109

This is the first figurative print Goyo completed in 1920, his most productive year. A modestly posed rendering of the waitress Onao, who is presented with a serving tray emblematic of her work, the print shows a marked difference from the artist's "toilette" studies. Goyō projects his subject's considerable strength through the bold arrangement of colours and contrasting forms. A dark mica background frames the subject, establishing a dramatic contrast with the woman's face and enhancing the figure's dimensionality. 
HASHIGUCHI GOYŌ (1880-1921)

\section{Woman combing her hair}

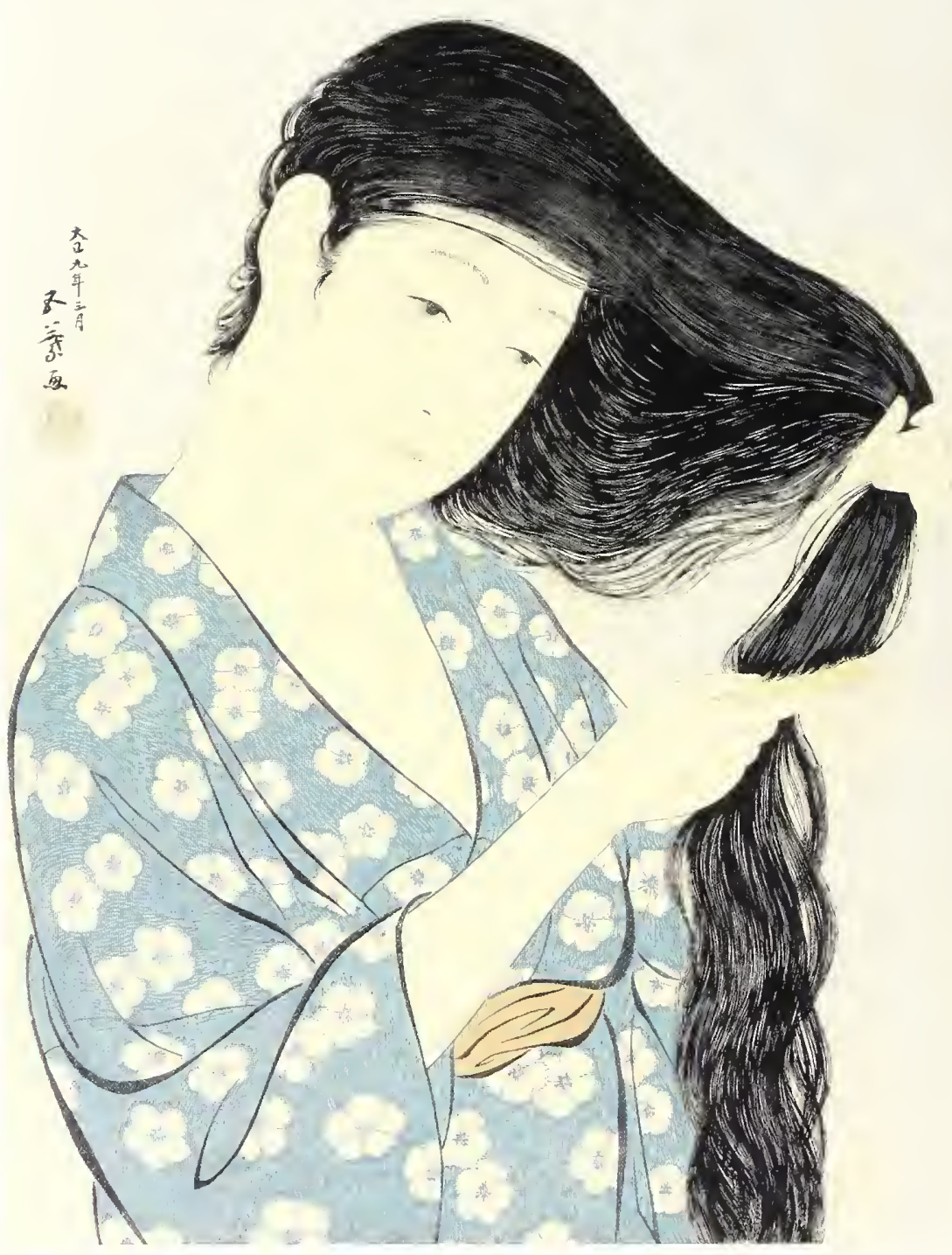

Japan, 1920

Woodblock print; ink and colour on paper

$46 \times 34.6 \mathrm{~cm}$

Arthur M. Sackler Gallery, Smithsonian Institution,

Washington D.C.; Robert O. Muller Collection

Inv. no. $\$ 2003.8 .121$

Goyō's astute attention to the production process of his prints was amply rewarded and nowhere more evident than in this image of model Tomi combing her long, dark hair. The patterning on the garment and the precisely rendered details of her hair, whose colour gradations reveal the artist's commitment to conveying form, and the combination of exquisite block cutting and inking creates a sense of density in the hair. 


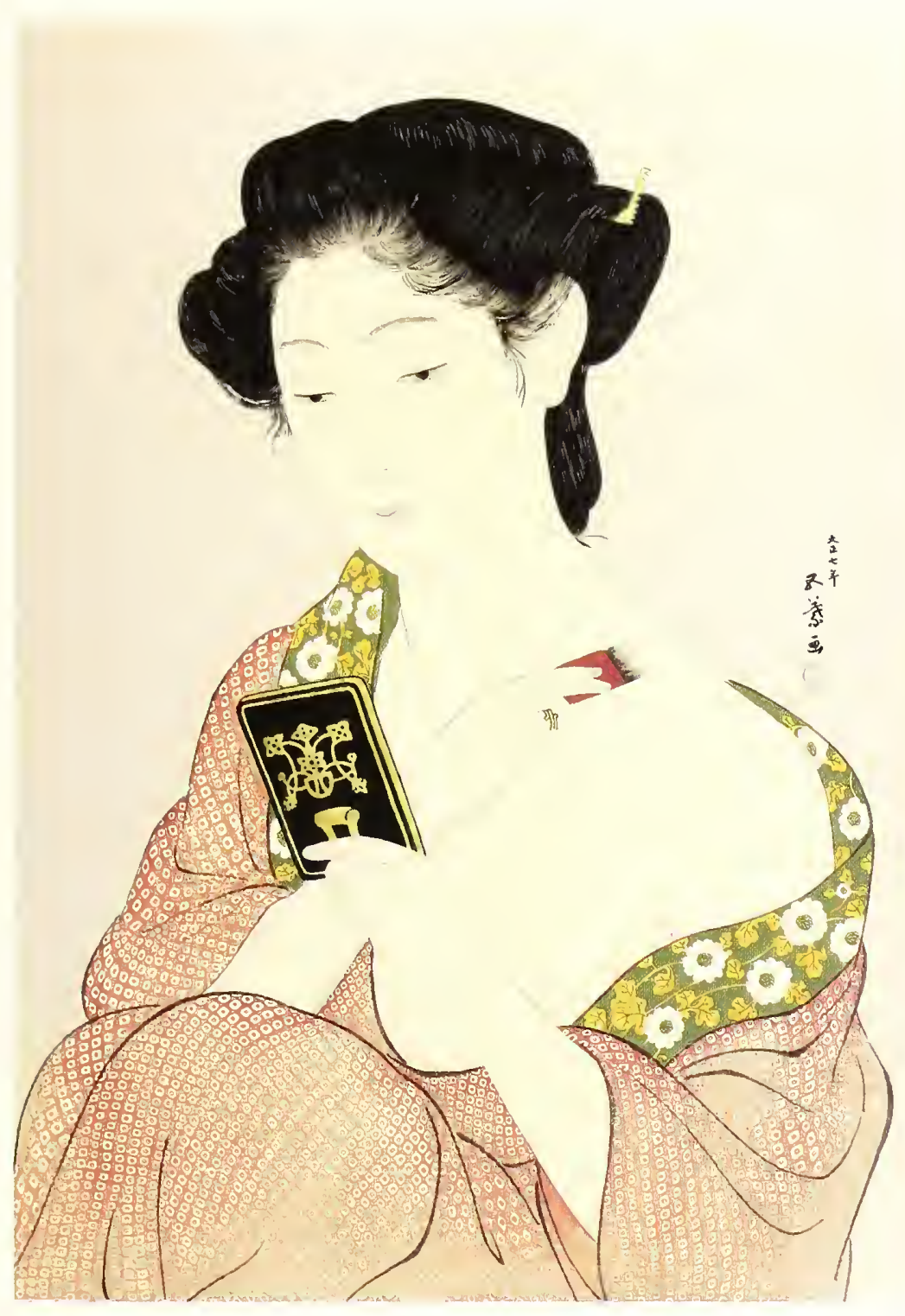

HASHIGUCHI GOYŌ (1880-1921)

Woman applying make-up

Japan, 1918

Woodblock print; ink, colour, gold and mica on paper

$53.3 \times 38.1 \mathrm{~cm}$

Arthur M. Sackler Gallery, Smithsonian Institution,

Washington D.C.; Robert O. Muller Collection

Inv. no. 52003.8 .120

This striking image of a woman applying powder to her shoulder was the first figure print for which Goyo assumed both the role of designer and of publisher. He took on these full production responsibilities after an unsatisfactory collaboration with the publisher Watanabe Shōzabūrō in 1915.

Goyō was an inveterate researcher of pre-modern print masters. In 1915 he published an article on the prints of Utamaro (1753-1806), and the image seen here strongly evokes the features found in that master's work, including the use of strong mica background to frame half-length portraits of women at their toilette. The sensitive rendering of volume through line and pattern indicates Goyō's mastery of Western painting and drawing techniques, which he studied at the Tokyo School of Fine Arts. 
HASHIGUCHI GOYŌ (1880-1921)

\section{Woman in a long undergarment}

Japan, 1920

Woodblock print; ink and colour on paper

$49.2 \times 15.5 \mathrm{~cm}$

Arthur M. Sackler Gallery, Smithsonian Institution,

Washington D.C.; Robert O. Muller Collection

inv. no. $\$ 2003.8 .104$

All elements of this beauty study are designed to enhance the stately and slender image of the woman. The depiction of the model, Tomi, with the garment's belt dangling from her mouth is Goyō's quotation of a pre-modern erotic cliché. Close examination of this work reveals Goyō's reliance on gauffrage (the use of an un-inked carved block to emboss the paper with the block's impression) to convey both suggested and actual volume to her robe. While Goyō has produced what appears to be a traditional Japanese print, he has done so with a range of thoroughly Western strategies that elicits fullness, volume, and texture.

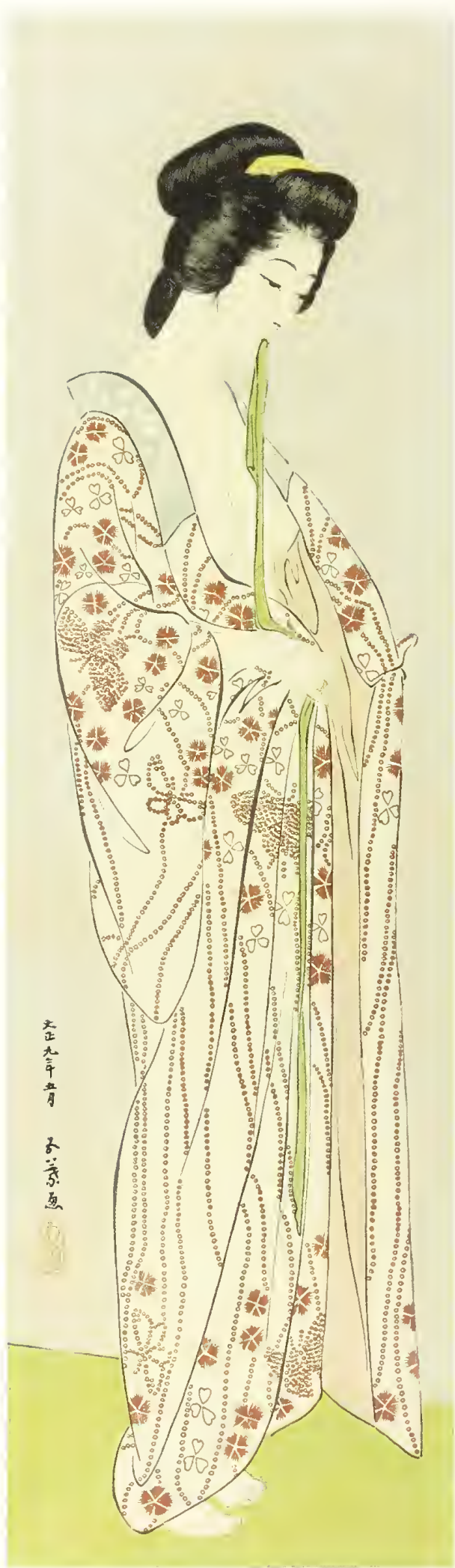




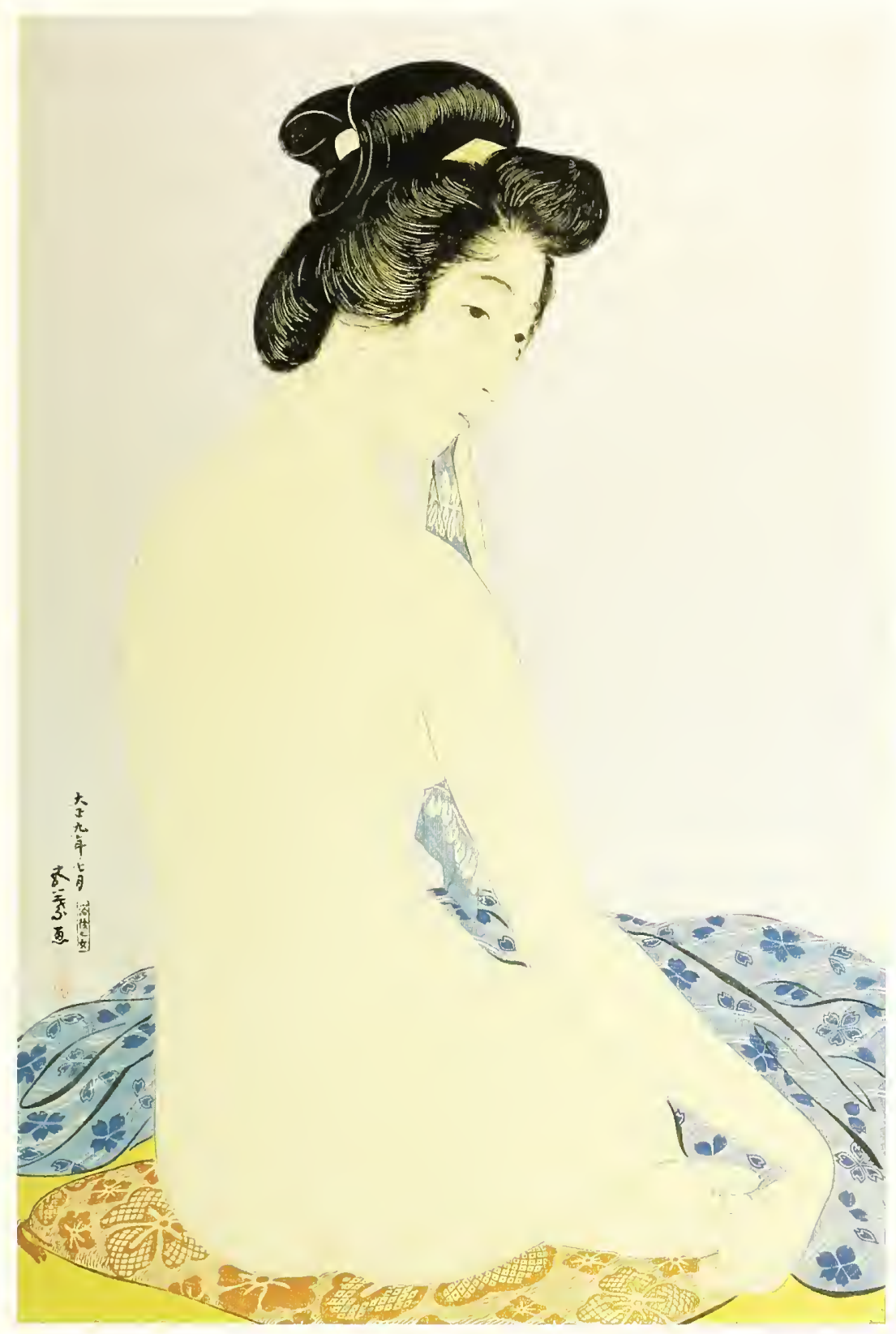

HASHIGUCHI GOYŌ (1880-1921)

Woman after a bath

Japan, 1920

Woodblock print; ink and colour on paper $46 \times 31.1 \mathrm{~cm}$

Arthur M. Sackler Gallery, Smithsonian Institution, Washington D.C.; Robert O. Muller Collection Inv no. $\$ 2003.8 .107$

Goyō's most active year of print production was 1920. He died the following year, leaving a number of unfinished projects that were subsequently completed by his family. For this and two other 1920 prints, Goyō used a model known as Tomi. The scant information available suggests that she was either a waitress or a geisha who also took jobs as a model in the Kanda district of Tokyo. The elegantly posed study is as reminiscent of a $19^{\text {th }}$-century French salon painting as it is an evocation of earlier Japanese print masters. 
ITŌ SHINSUI (1898-1972)

After the bath

Japan, 1917

Woodblock print; ink and colour on paper

$45 \times 30.5 \mathrm{~cm}$

Arthur M. Sackler Gallery, Smithsonian Institution,

Washington D.C.; Robert O. Muller Collection

Inv. no. $\$ 20038.252$

This deceptively simple design of a young woman at her toilette, a classic subject in the Japanese print tradition, was produced by Shinsui at the age of eighteen and marked the beginning of a collaboration with print publisher Watanabe Shōzaburō that lasted until 1962. Artist and publisher produced over one hundred sixty prints, with nearly one hundred of them featuring beautiful women. Such intimate views gained popularity in European Impressionist paintings, which ironically had also been influenced by early Japanese prints. Shinsui's "re-Japanization" of this theme ultimately returned the central motif of bijinga (beauty prints) to its point of origin.

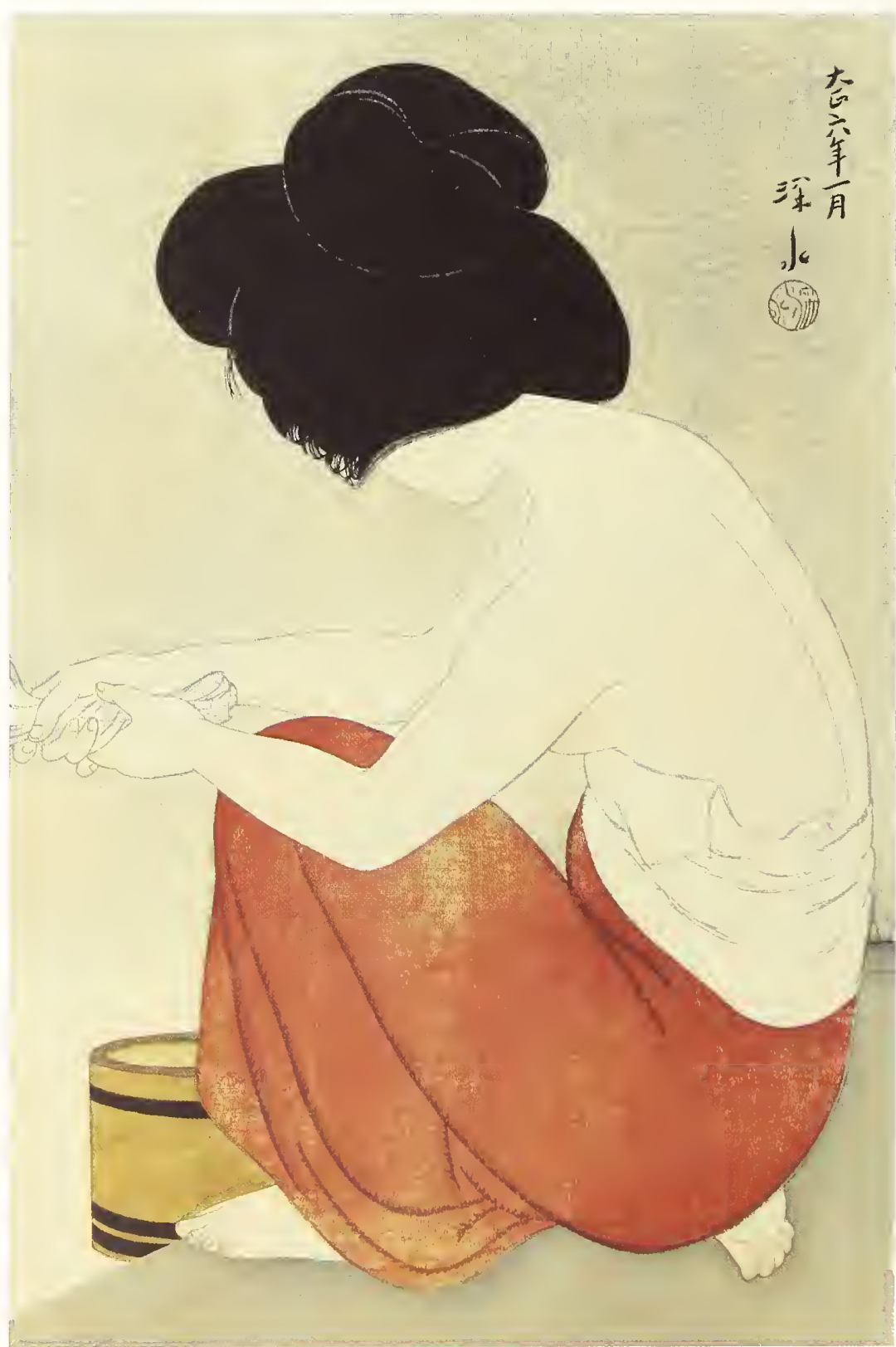




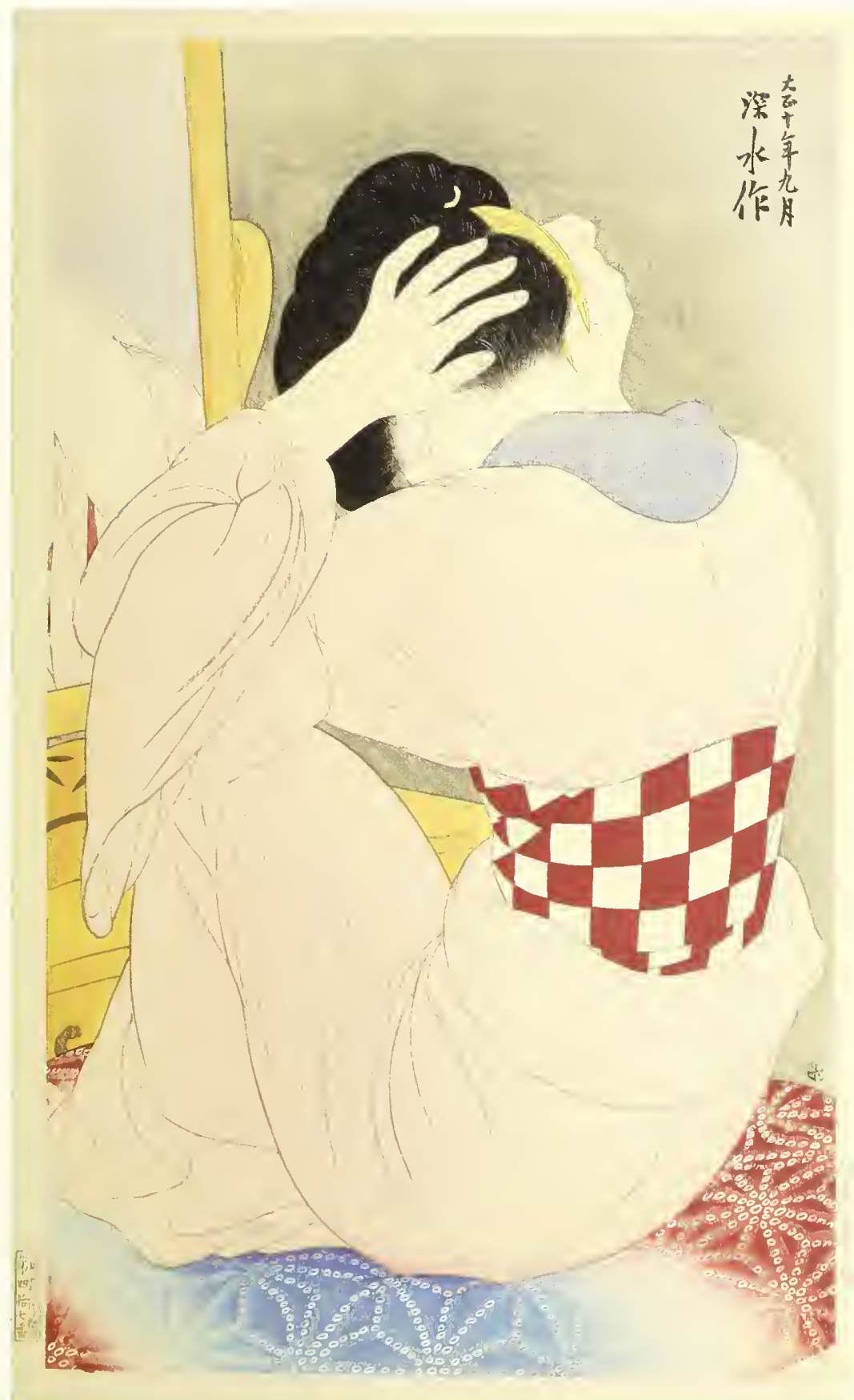

ITŌ SHINSUI (1898-1972)

A girl dressing her hair

Japan, 1921

Woodblock print; ink and colour on paper

$43 \times 26.2 \mathrm{~cm}$

Arthur M. Sackler Gallery, Smithsonian Institution,

Washington D.C.; Robert O. Muller Collection

Inv. no. $\$ 2003.8 .256$

With the death of Hashiguchi Goyō (1880-1921) only several months before this print was produced, Shinsui's status as the premier artist of the female beauty genre was solidified. Unlike Goyō's careful studies of his subjects' faces, Shinsui often allows posture to proclaim personality, as he does with the woman here who presents her back to the viewer. The artist intensifies the intrigue of her identity by showing a glimpse of her bare forearm in the mirror - but not her face. Not coincidentally, such rear views allow Shinsui to focus on the nape of the neck, classically regarded as a point of erotic titillation. 
ITŌ SHINSUI (1898-1972)

Painting the eyebrows

Japan, 1928

Woodblock print; ink and colour on paper

$29 \times 40.2 \mathrm{~cm}$

Arthur M. Sackler Gallery, Smithsonian Institution,

Washington D.C.; Robert O. Muller Collection

inv. no. $\$ 2003.8 .289$

This image ranks as one of Shinsui's most popular and powerful bijin (beauty) studies. Shinsui shows a geisha applying make-up, the band around her head anticipating the imminent placement of a wig. The delicately poised hand usually seen in these prints, often fussing with tresses, here holds an inked brush, ready to lend definition to the eyebrows. The artist challenges the conventional depiction of female reverie, presenting instead a woman thoroughly focused, with a sense of professionalism, on the task of rendering the precise lines of her own carefully designed self-image. The daring use of a deep red background recalls the emblematic colour of the pleasure quarters.

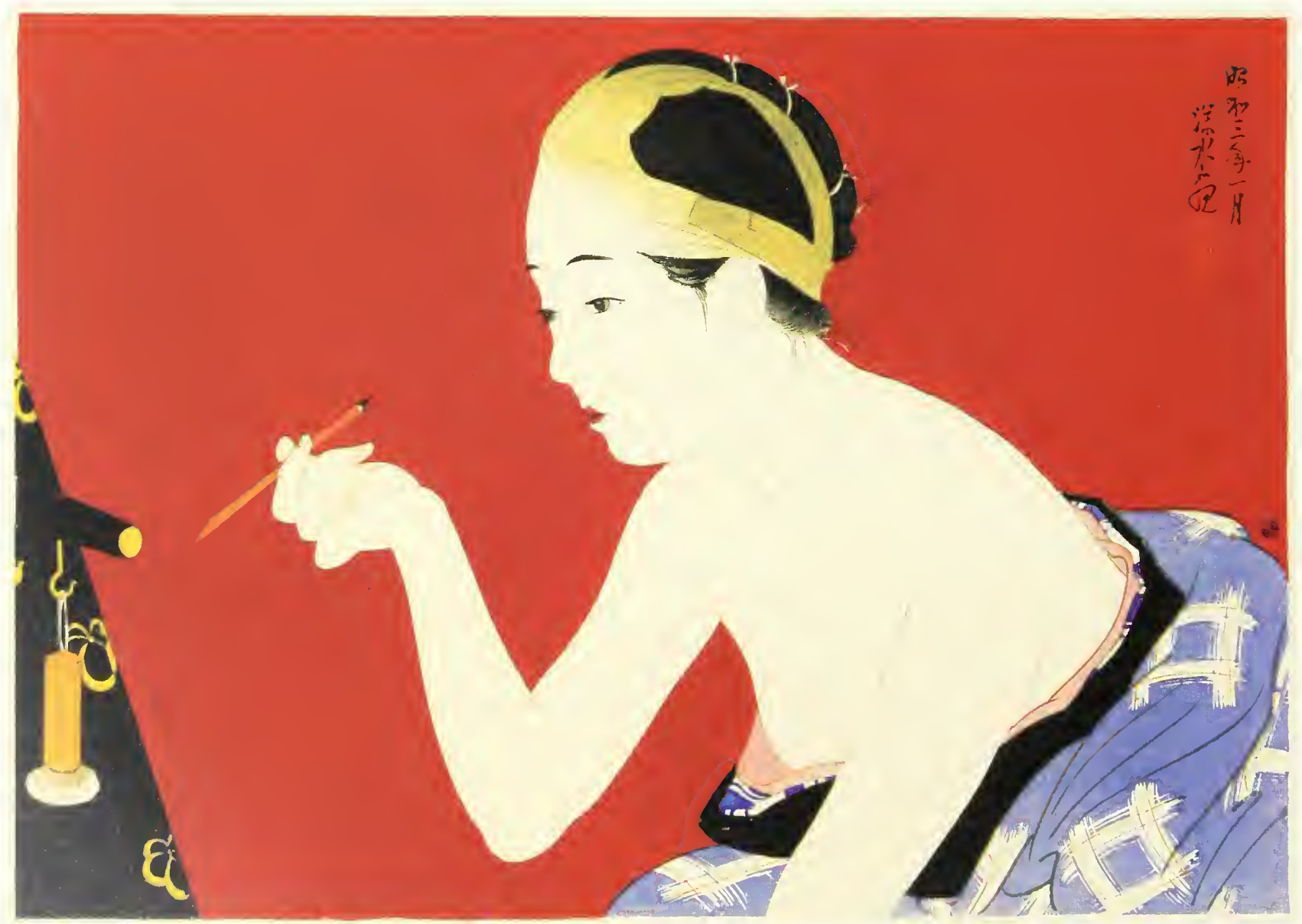




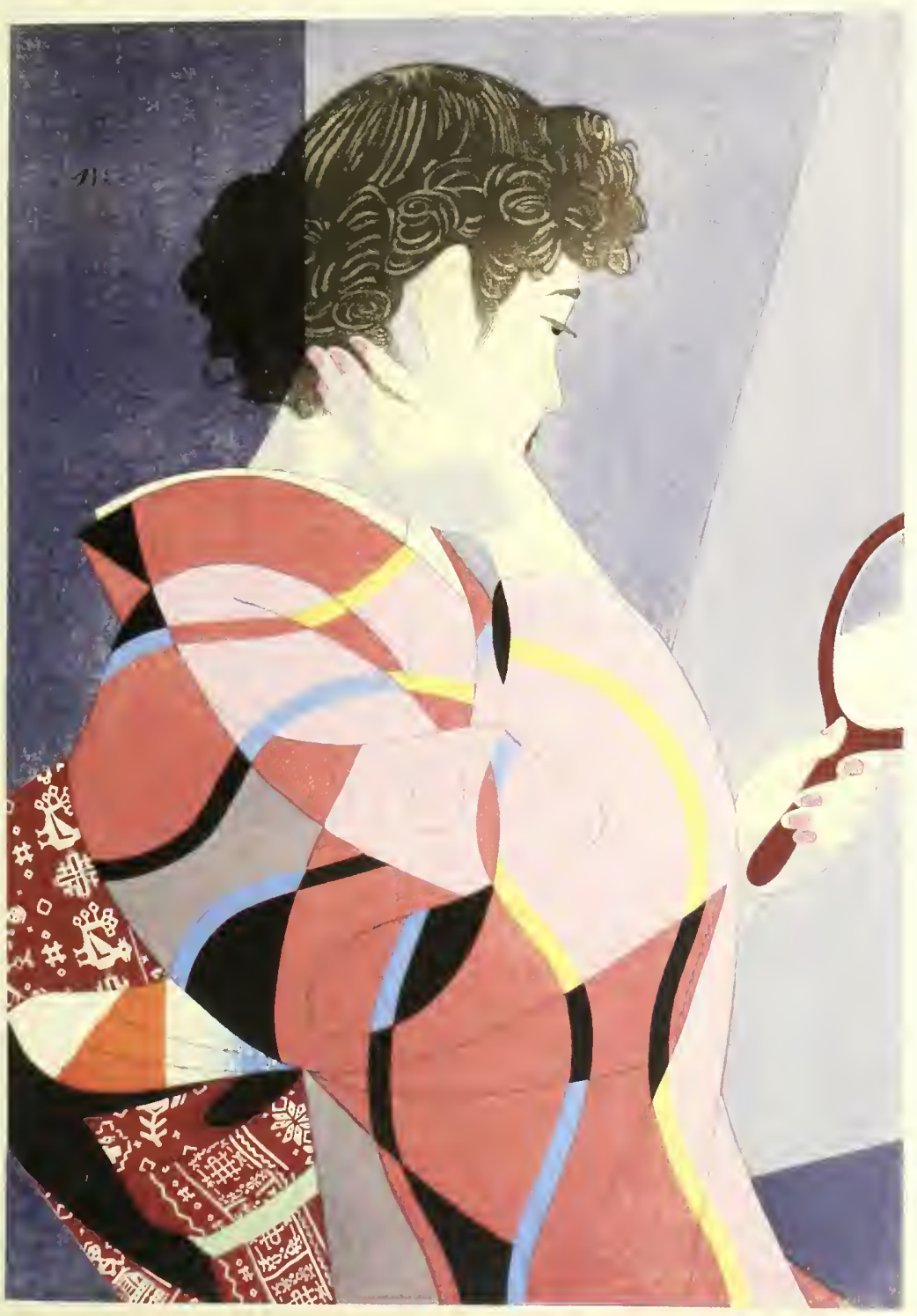

ITŌ SHINSUI (1898-1972)

With the hand mirror

Japan, 1953

Woodblock print; ink and colour on paper

$49 \times 35 \mathrm{~cm}$

Arthur M. Sackler Gallery, Smithsonian Institution,

Washington D.C.; Robert O. Muller Collection

Inv. no. $\$ 2003.8 .314$

This print shows Shinsui verging closer to abstraction than at any other time in his career. The woman, examining her appearance in a mirror, assumes a traditional pose, but the hair she primps bears no resemblance to the more architectural coiffures of the past - it is, rather, pure 1950s. The waves and curls of her hair are schematically rendered with white or light-coloured lines - certainly no intricate challenge for the block cutter's art. Shinsui seems to have forsaken the nostalgic feel of his pre-war prints for this immersion in the contemporary. His excitement lies with form and colour in a quasi-Cubist mode. 
THE QUALITY OF LIGHT 
Nothing so distinguishes Japanese printmakers of the modern era as does their persistent interest in depicting light. This was particularly fundamental to their treatment of city and landscapes. Since the $17^{\text {th }}$ century the woodblock print had been the favoured vehicle for rendering Japan's energetic life of urban theatre and bordello, but beginning in the late $18^{\text {th }}$ century landscapes provided an alternative to that introspective world, suggesting the increasingly more expansive interests of the audience. Pre-modern printmakers identified discernible canon of recognizable geographic places; modern printmakers, however, emphasized the exploration of mood and atmosphere in place. Kobayashi Kiyochika (1847-1915), perhaps the most important innovator in landscape genre of the modern era, set the visual agenda by attending to the modern night, then newly accessible by electric light. His nocturnes - experiments in depicting a range of light sources in darkened environments offered alternatives to photography and, indeed, new ways of looking at familiar places. Kiyochika gave primacy to the mood of place. His initiative spurred artists of the later Shin-hanga generation to explore the thematic possibilities inherent in night scenes and light in all its manifestations. Their carefully created atmospheres cast a soft, gentle scrim on their already romanticized views of an idealized Japan that was swiftly changing. 
YOSHIDA HIROSHI (1876-1950)

Sailing boats, sunset

From the series 'Inland sea' (Seto naikai shū) Japan, 1921

Woodblock print; ink and colour on paper $45.3 \times 33 \mathrm{~cm}$

Arthur M. Sackler Gallery, Smithsonian Institution, Washington D.C.; Robert O. Muller Collection Inv no. $\$ 2003.8 .3450$

\section{YOSHIDA HIROSHI (1876-1950)}

\section{Sailing boats, morning}

From the series 'Inland sea' (Seto naikai shū)

Japan, 1926

Woodblock print; ink and colour on paper

Overall (trimmed): $51 \times 36 \mathrm{~cm}$

Arthur M. Sackler Gallery, Smithsonian Institution, Washington D.C.; Robert O. Muller Collection Inv. no. $\$ 2003.8 .3461$

\section{YOSHIDA HIROSHI (1876-19S0)}

\section{Sailing boats, mist}

From the series 'Inland sea' (Seto naikai shū) Japan, 1926

Woodblock print; ink and colour on paper $50.9 \times 38 \mathrm{~cm}$

Arthur M. Sackler Gallery, Smithsonian Institution, Washington D.C.; Robert O. Muller Collection

Inv. no. $\$ 2003.83459$

\section{YOSHIDA HIROSHI (1876-1950)}

\section{Sailing boats, afternoon}

From the series 'Inland sea' (Seto naikai shū)

Japan, 1926

Woodblock print; ink and colour on paper $51 \times 36 \mathrm{~cm}$

Arthur M. Sackler Gallery, Smithsonian Institution, Washington D.C.; Robert O. Muller Collection Inv. no. $\$ 2003.8 .3458$

\section{YOSHIDA HIROSHI (1876-19S0)}

\section{Sailing boats, night}

From the series 'Inland sea' (Seto naikai shū) Japan, 1926

Woodblock print; ink and colour on paper

$51 \times 36 \mathrm{~cm}$

Arthur M. Sackler Gallery, Smithsonian Institution, Washington D.C.; Robert O. Muller Collection Inv. no. $\$ 2003.8 .3460$

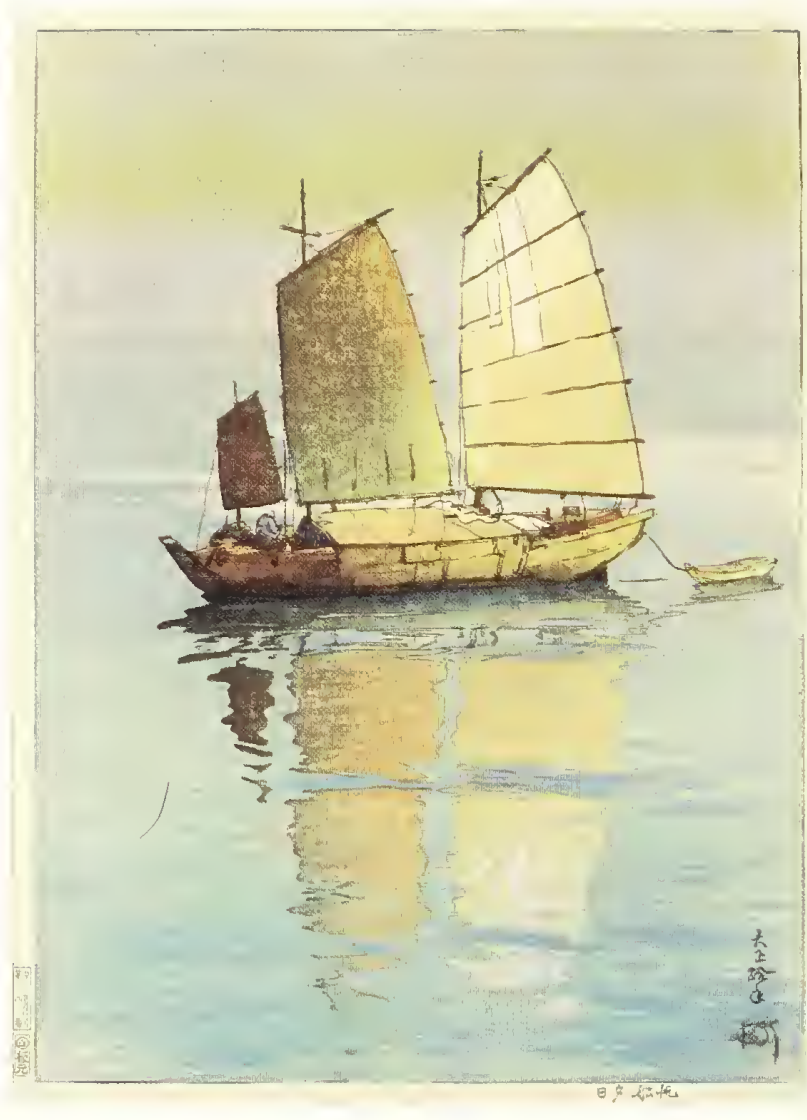

In 1927, Yoshida's Inland sea series became the first prints accepted into the prestigious salon exhibition Teiten, the Imperial Academy of Fine Arts Exhibition. Admission of the print format into the official salon was a major step for a medium viewed as plebeian. Up to that point, only painting and sculptural media had been accepted. Of the five impressions presented here, only the sunset scene (cat. no. 45) dates from before the 1923 Great Kantō Earthquake. The print's original blocks were destroyed during the earthquake, along with the print shop of Watanabe Shōzaburō, who published the work. Three years later, in 1926, Yoshida - who had been particularly fond of that image - recreated the design, and printed and published new impressions, this time from his own print shop. The resulting series was his best-known effort at rendering the same scene in a range of atmospheric conditions. 

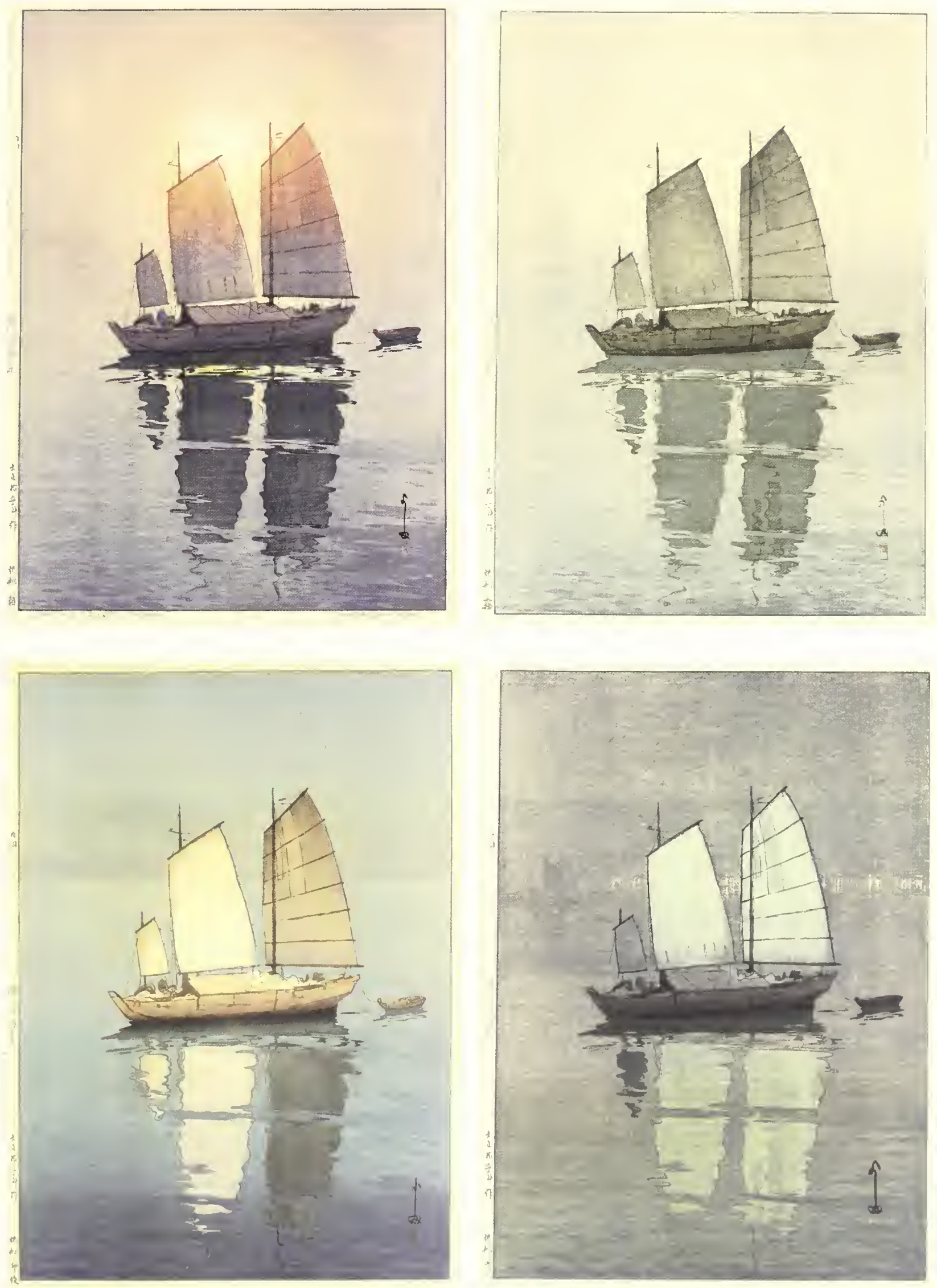
KAWASE HASUI (1883-1957)

\section{The Okane Road, Shiobara}

Japan, 1918

Woodblock print; ink and colour on paper $45.4 \times 16.8 \mathrm{~cm}$

Arthur M. Sackler Gallery, Smithsonian Institution, Washington D.C.; Robert O. Muller Collection Inv. no. $\$ 2003.8 .560$

In 1918 Hasuidebuted as one ofpublisher WatanabeShōzaburō's artists with a set of three vertical landscapes, of which this is one. All depicted views of Shiobara, a famous hot spring in the mountainous Tochigi Prefecture on Honshū, Japan's central island. A sickly child, Hasui had spent a great deal of time at Shiobara, and scenes of the region lingered in his imagination. He called it his "birthplace" - and it was surely an appropriate subject for his first Shin-hanga works.

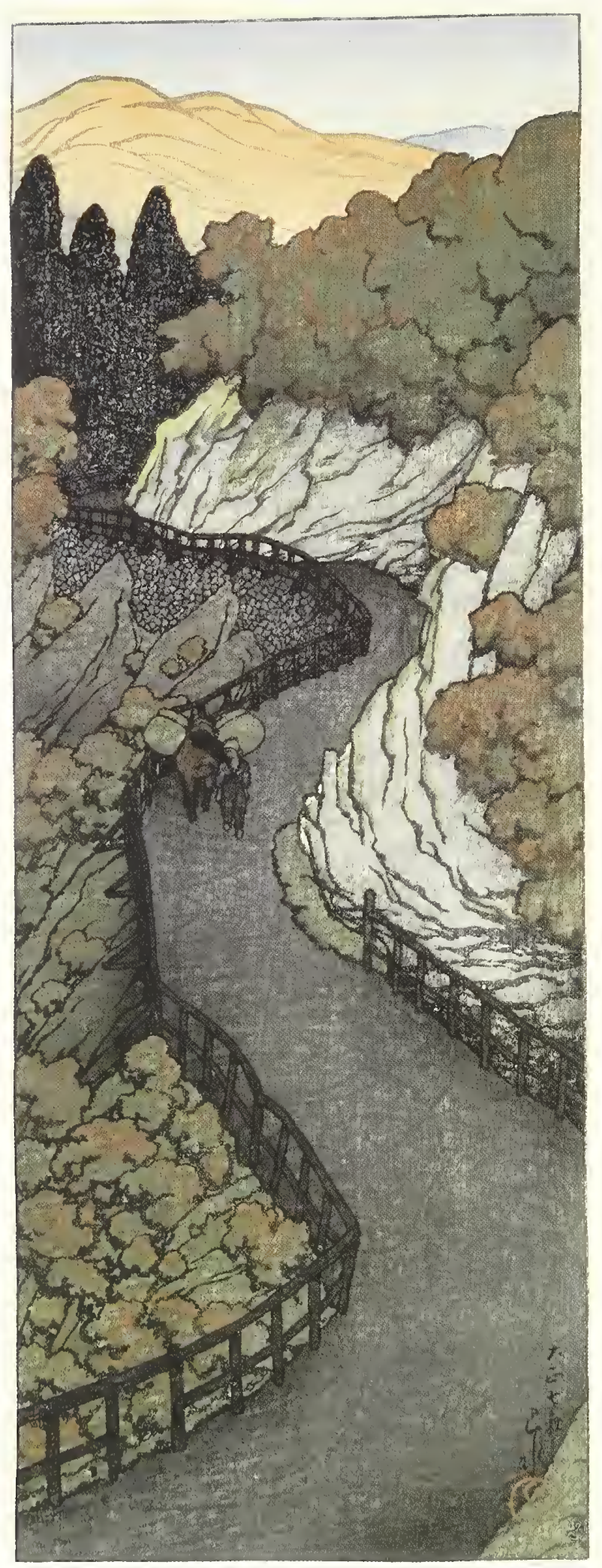




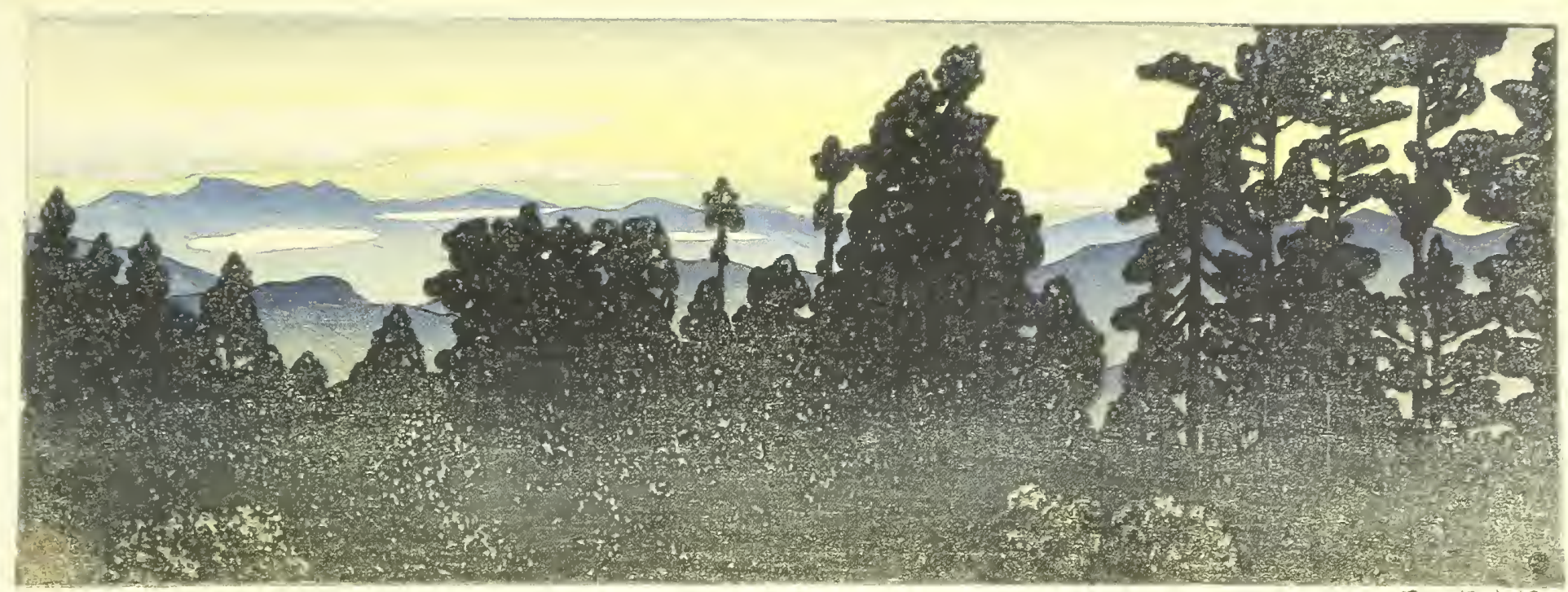

真9 19 多得

KAWASE HASUI (1883-1957)

\section{Summer in Ikaho}

Japan, 1919

Woodblock print; ink and colour on paper

$16.8 \times 45.5 \mathrm{~cm}$

Arthur M. Sackler Gallery, Smithsonian Institution,

Washington D.C.; Robert O. Muller Collection

Inv. no. $\$ 2003.8 .564$

Hasui was one of several of the Watanabe Shōzaburō artists who attempted to translate painting techniques into the print medium. The combination of embossed clouds, gradations of blue, and shadowy masses of trees creates a texture suggesting thickly applied oil pigments, rather than the colour schemes of traditional Ukiyo-e prints. In this and other early prints by Hasui, the use of a dark silhouette in the foreground reflects the pervasive influence of Kobayashi Kiyochika's earlier experiments with severe dark-light contrasts. 
KAWASE HASUI (1883-1957)

\section{Dawn at Dōtonbori, Osaka}

From the series 'Souvenirs of travels', second collection (Tabimiyage dai ni shü)

Japan, 1921

Woodblock print; ink and colour on paper

$24.5 \times 36.6 \mathrm{~cm}$

Arthur M. Sackler Gallery, Smithsonian Institution, Washington D.C.; Robert O. Muller Collection

Inv. no. $\$ 2003.8 .612$

In this second of his series of travel images, Hasui memorialized a scene favoured by several of the Shin-hanga artists - that of Dōtonbori, an entertainment center in Osaka. Several pleasure craft, which hint at a robust nightlife, are now peacefully docked. Hasui effectively conveys the early morning sun as it burns the mist off the river. The few indications of activity - circling birds, traffic on the bridge and the river - are clustered at the left of the print, just where the daylight begins to break into the scene. With the exception of the black registry lines, Hasui largely avoids precise definition, thus producing a study in dark tones of indigo. The result is a sense of monumental quiet.
KAWASE HASUI (1883-1957)

\section{Hyōjōgawara, Sendai}

\section{Japan, 1919}

Woodblock print; ink and colour on paper

$16.6 \times 45.6 \mathrm{~cm}$

Arthur M. Sackler Gallery, Smithsonian Institution, Washington D.C.; Robert O. Muller Collection

Inv. no. $\$ 2003.8 .567$

As a summer squall swells the rapids of the river, a lone farmer rushes across a wooden footbridge. The setting is the Hirose River on the Pacific coast, near the city of Sendai, in northern Honshū. Particularly in the early years of their collaboration, from 1918 to 1921, Hasui and his publisher Watanabe Shōzaburō successfully experimented with a variety of non-traditional print formats, trying to create a new type of landscape. This horizontal choice permits a panoramic view that dominates not only the small figure but also the entire composition. In the pre-modern era of print design, such a composition would more likely have been structured as a triptych. 

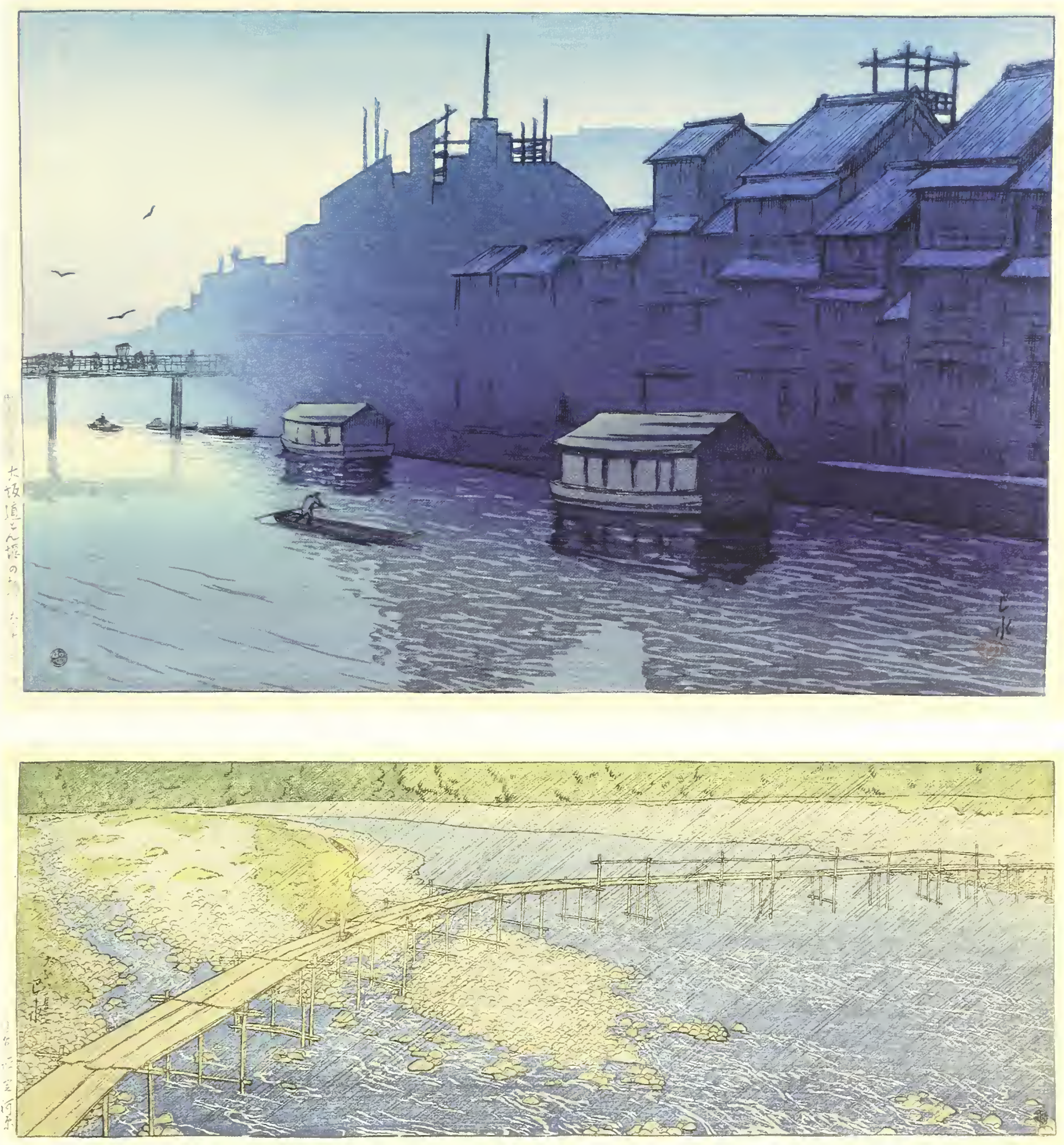
HASHIGUCHI GOYŌ (1880-1921)

Rain at Yabakei Valley, Kyushu

Japan, 1918

Woodblock print; ink and colour on paper

$37.2 \times 50 \mathrm{~cm}$

Arthur M. Sackler Gallery, Smithsonian Institution,

Washington D.C.; Robert O. Muller Collection

Inv. no. $\$ 2003.8 .117$

Goyō, who was best known for his renderings of the female form, created many more paintings and drawings than prints. In fact, this impression is the first of only a few landscape prints he produced. Based on a sketch he made during a 1910 trip to the scenic Yabakei Valley in southern Japan, this landscape combines his experience with Western-style oil painting and the palette of traditional printmakers. The silver-coloured rain is a feature found only in the first edition of this print.

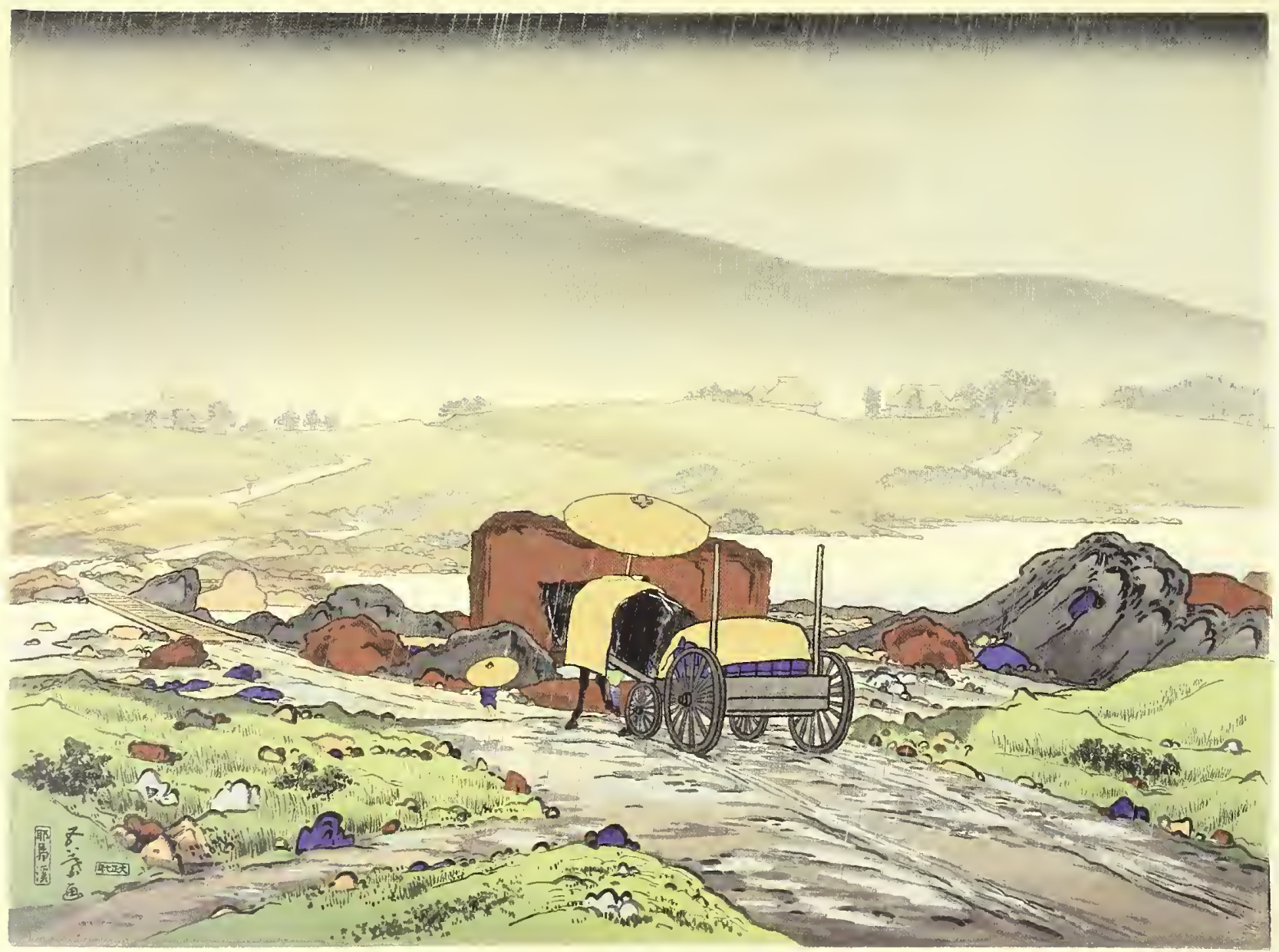




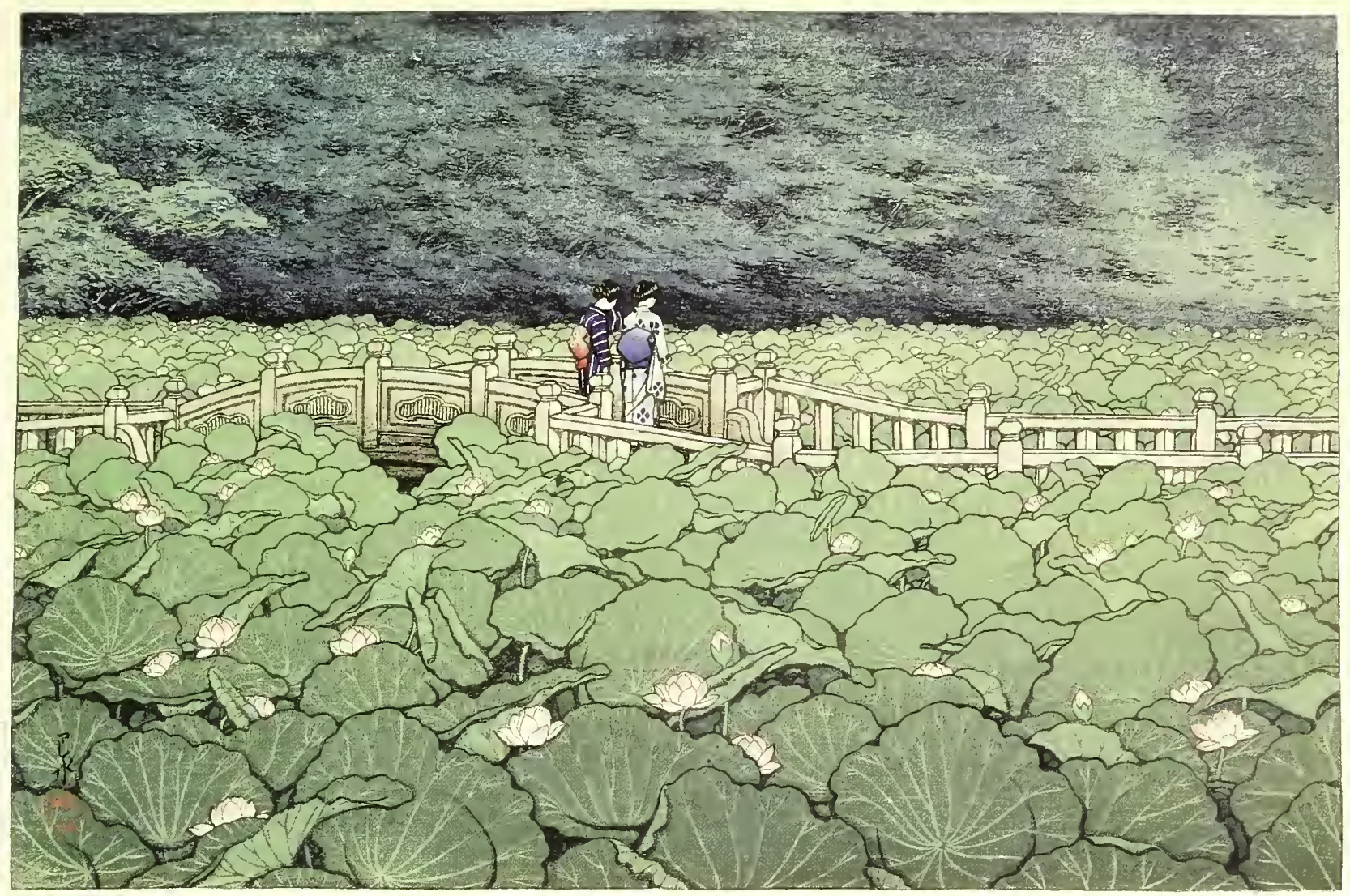

55. KAWASE HASUI (1883-1957)

\section{Benten Pond, Shiba}

Japan, 1929

Woodblock print; ink and colour on paper $24.2 \times 36.4 \mathrm{~cm}$

Arthur M. Sackler Gallery, Smithsonian Institution, Washington D.C.; Robert O. Muller Collection inv. no. $\$ 2003.8 .717$
Hasui's forte was the design of landscape prints, particularly the exploration of mood as achieved by varying permutations of light. The density and range of green tonalities impress upon the viewer a sense of summer at its humid peak. The explosive energy of the midsummer's lush growth of lotus is counterbalanced by the poised, contemplative presence of the two women crossing a bridge. Hasui's choice of traditional kimono - a deliberate evocation of a romanticized theme - contradicts the harsher reality that Western fashion had become the workaday standard in Tokyo. The summer spectacle of Benten Pond, located in Shiba Park, in the south-eastern section of Tokyo, has been an annual tourist destination since the park opened to the public in 1873 . 
KAWASE HASUI (1883-1957)

Zōjōji in the snow

from the series "Souvenirs of travels", second collection

(Tabimiyage dai ni shū)

Japan, 1922

Woodblock print; ink and colour on paper

$37 \times 23.4 \mathrm{~cm}$

Arthur M. Sackler Gallery, Smithsonian Institution,

Washington D.C.; Robert O. Muller Collection

Inv. no. $\$ 2003.8 .643$

When asked in 1953 - more than thirty years after the creation of this print - by a government committee to submit exemplary works from his oeuvre, Hasui returned to the familiar image of Zōjōji. Hasui was born and raised in the vicinity of this ancient temple, a fact that may account for his affection for and frequent depictions of it. At one time this stunning visual landmark, located in the south-central Shiba ward of Tokyo, enjoyed particular prestige as the shogunate's family temple and burial ground.

The combination of subject and season allowed the artist to explore the bold colour contrasts between the rich red of the architecture and the bright white of the snow. Over the course of his career Hasui experimented with characterizations of the atmospheric conditions of falling snow. In this early work, the flakes are distinct and large; in later works, the snow is rendered as dense and encompassing.
KAWASE HASUI (1883-1957)

\section{The Great Gate, Shiba}

Japan, 1936

Woodblock print; ink and colour on paper

$32 \times 22.7 \mathrm{~cm}$

Arthur M. Sackler Gallery, Smithsonian Institution, Washington D.C.; Robert O. Muller Collection

Inv. no. $\$ 2003.8 .853$

This print suggests a quiet, muted meeting of the traditional and the modern realms. Zöjōji, a Buddhist temple located in the heart of modern Tokyo, traces its origins to the $9^{\text {th }}$ century but enjoyed especially great prestige throughout the Edo period (1615-1868) because it was the favoured temple of the Tokugawa shogunate. An automobile bearing uniformed chauffeur and passenger with fedora visible seem to cautiously navigate into the ancient compound. This effective, slightly melancholic essay about the reception of modernity is ironically undermined by the fact that the red temple gate is a concrete reproduction. The earlier wooden structure was relocated to another temple after the gate sustained damage during the 1923 earthquake. 

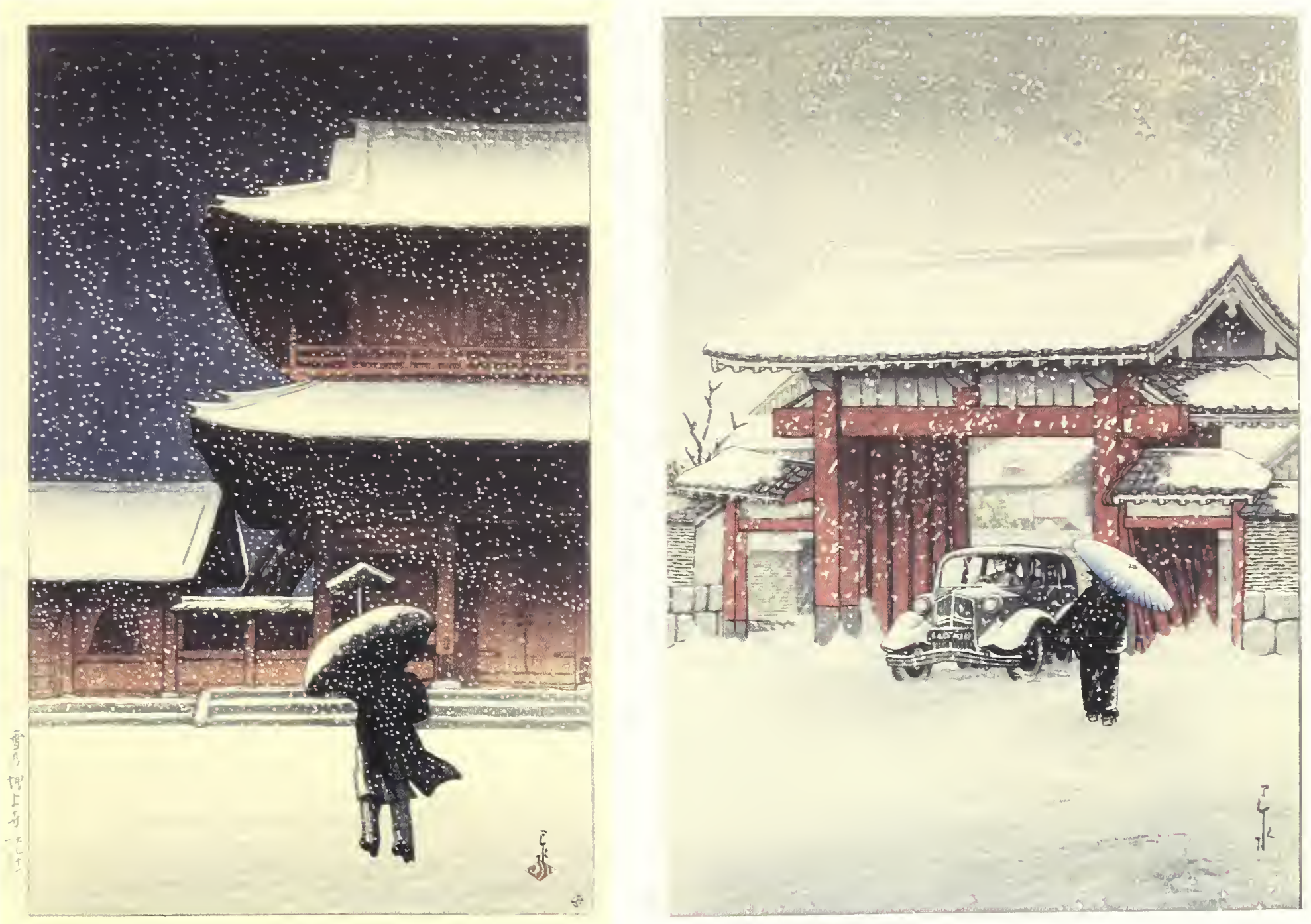


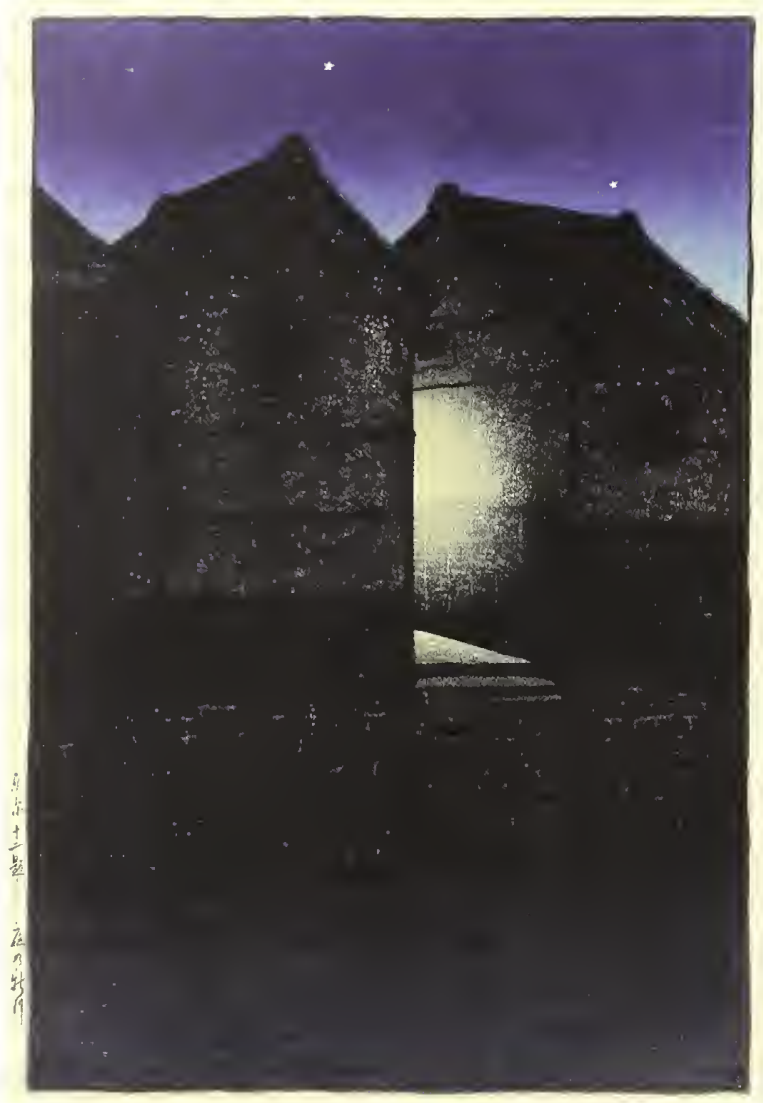

KAWASE HASUI (1883-1957)

\section{Shinkawa at night}

From the series 'Twelve scenes of Tokyo' (Tokyo jünidai)

Japan, 1919

Woodblock print; ink and colour on paper

$36.3 \times 24.4 \mathrm{~cm}$

Arthur M. Sackler Gallery, Smithsonian Institution,

Washington D.C.; Robert O. Muller Collection

Inv no. \$2003.8.577

Profoundly influenced by Itō Shinsui's series "Eight views of Ōmi", Hasui turned to printmaking. Included in his first series of Tokyo landscapes was this print, depicting warehouses on the man-made island of Shinkawa (Reiganjima), at the mouth of the Sumida River. Hasui, like his inspiration, Shinsui, experiments with subordinating the easily recognizable site to the rendering of atmosphere. In this study, Hasui probed the rich, dark tonalities of a night scene softened only by an electric light, issuing from between two structures, and a few lone stars. His approach - a formal study of tonalities - successfully obliterates the grittiness of the workaday warehouse scene.

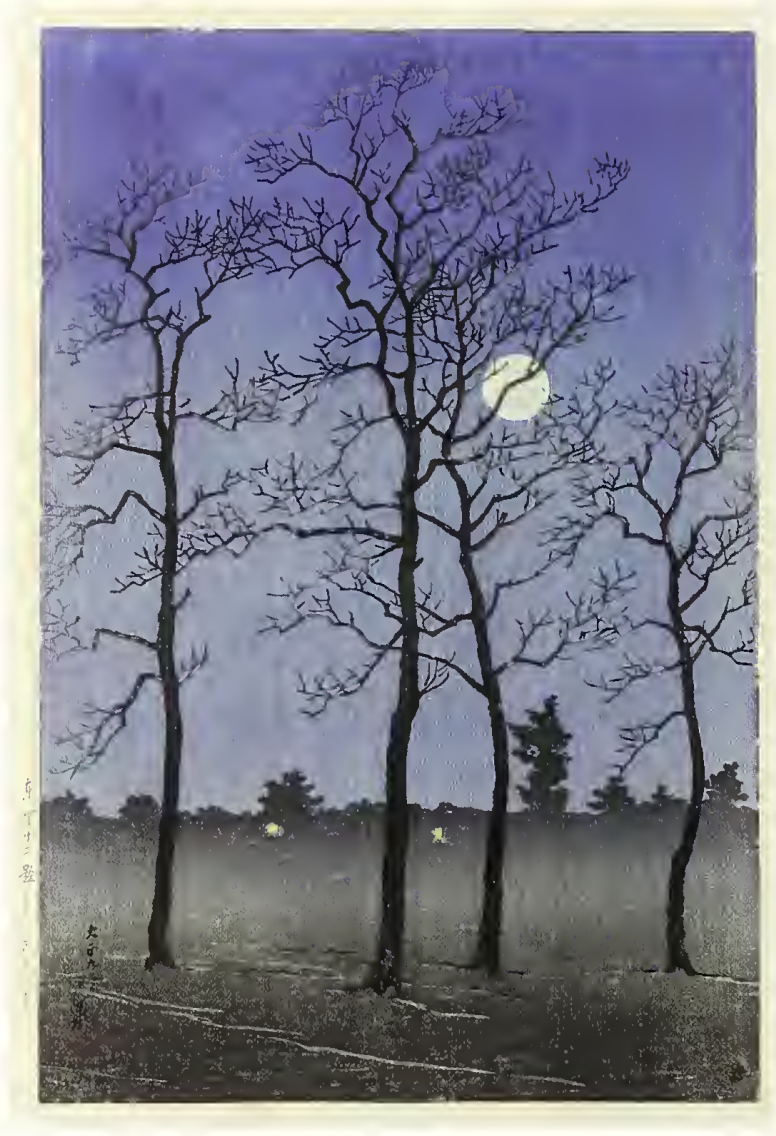

KAWASE HASUI (1883-1957)

Tōyama Plain

From the series 'Twelve scenes of Tokyo' (Tokyo jünidai)

Japan, 1920

Woodblock print; ink and colour on paper

$36.6 \times 24.5 \mathrm{~cm}$; Overall: $38.5 \times 26.6 \mathrm{~cm}$

Arthur M. Sackler Gallery, Smithsonian Institution,

Washington D.C.; Robert O. Muller Collection

Inv. no. \$2003.8.587

Tõyama Plain was one of Hasui's most successful creations. Hasui himself described the scene depicted in this popular print: "The moon threw off a blue-white light and the vagueness of the fire light on the other side of the forest and even the withered standing trees of winter appeared eerie." Unfortunately, the woodblocks for the version seen here, which was published by the Watanabe firm, were destroyed during the Great Kantō Earthquake (1923). The popularity of the design remained high, however, and a different publisher, Doi Sadaichi, produced another, nearly identical composition by Hasui in the 1930s. 


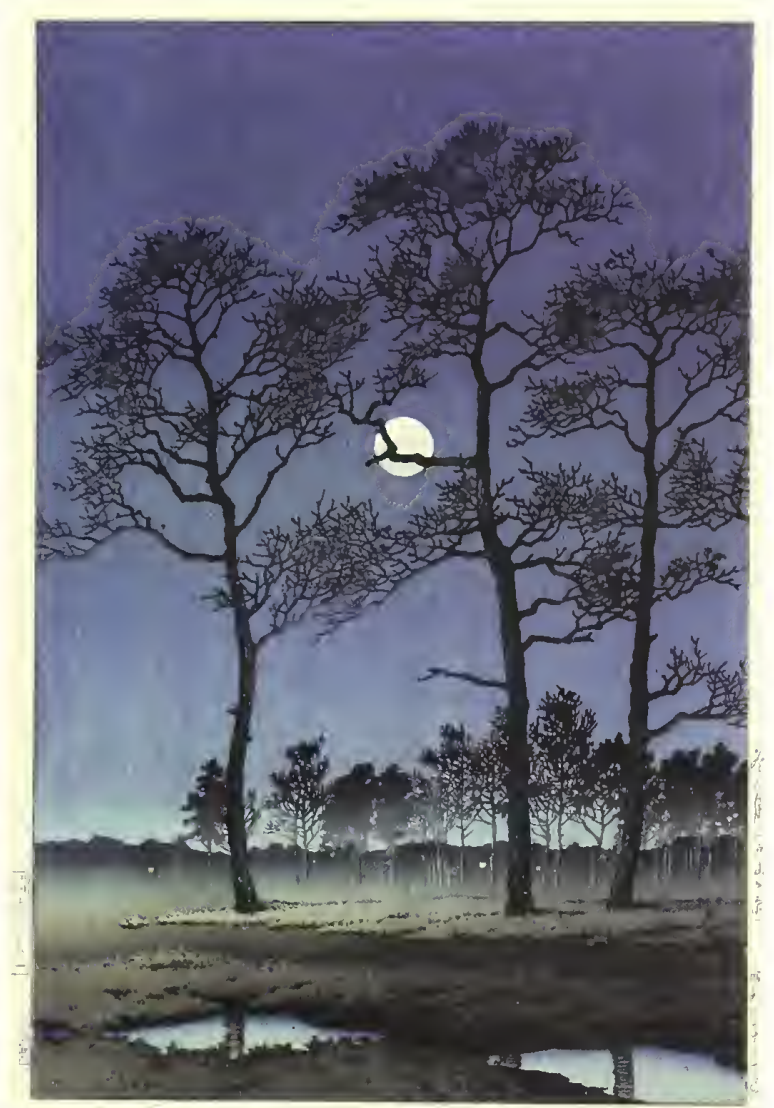

KAWASE HASUI (1883-1957)

Winter moon, Tỏyama Plain

Japan, 1931

Woodblock print; ink and colour on paper

$36.7 \times 24 \mathrm{~cm}$

Arthur M. Sackler Gallery, Smithsonian Institution, Washington D.C.; Robert O. Muller Collection

Inv. no. $\$ 2003.8 .743$

This print was created in response to the strong demand for Hasui's original 1920 design. This version, published by Doi Sadaichi, contains changes that include the addition of a crystalline surface to the water. The overall impression is graphically crisper than the pre-earthquake image.

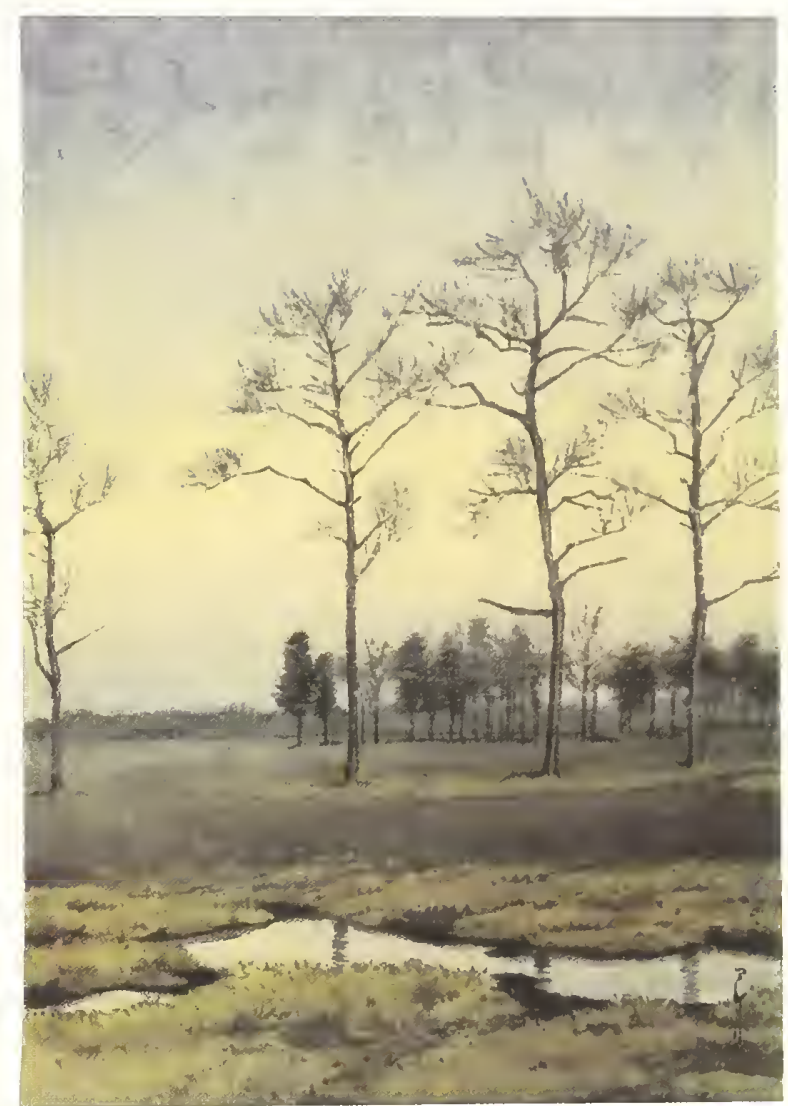

KAWASE HASUI (1883-1957) Tōyama Plain

Japan, 1937

Watercolour on paper

$37 \times 26.5 \mathrm{~cm}$

Arthur M. Sackler Gallery, Smithsonian Institution, Washington D.C.; Robert O. Muller Collection Inv. no. $\$ 2003.8 .533$

Years after the original Toyama Plain was published in 1920 , Hasui created this watercolour. While Hasui's watercolours have sometimes been misunderstood as design plans that preceded the production of a print, in actuality most were generated after the fact, possibly for clients who wanted "one-of-a-kind" works by the artist rather than one sheet from a multiple run. Hasui described himself as "a printmaker, pure and simple." He once commented about the joy of printmaking: "[I]n painting, you might lose focus while playing with lines and colouring, but print comes to life at once, and the joy of that moment is of unsurpassable heaven for printmakers." 


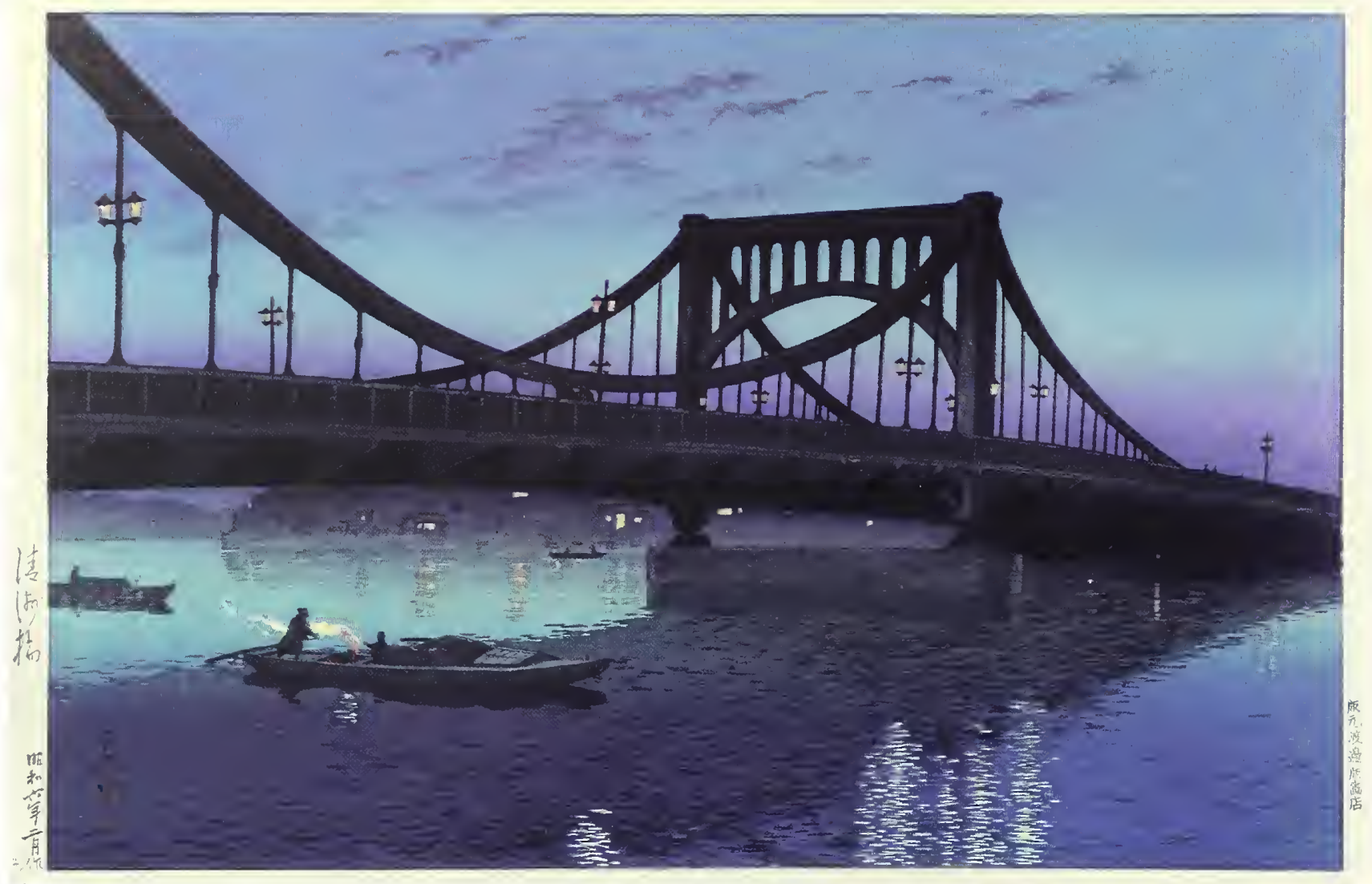

2. KAWASE HASUI (1883-1957)

Kiyosu Bridge

Japan, 1931

Woodblock print; ink and colour on paper

$24.2 \times 36.5 \mathrm{~cm}$

Arthur M. Sackler Gallery, Smithsonian Institution,

Washington D.C.; Robert O. Muller Collection

Inv no. $\$ 2003.8 .761$

Modelled after a European suspension bridge, Kiyosu was one of many structures rebuilt in Tokyo's lengthy recovery from the 1923 Great Kantõ Earthquake and the subsequent fires that destroyed more than two-thirds of the city. 


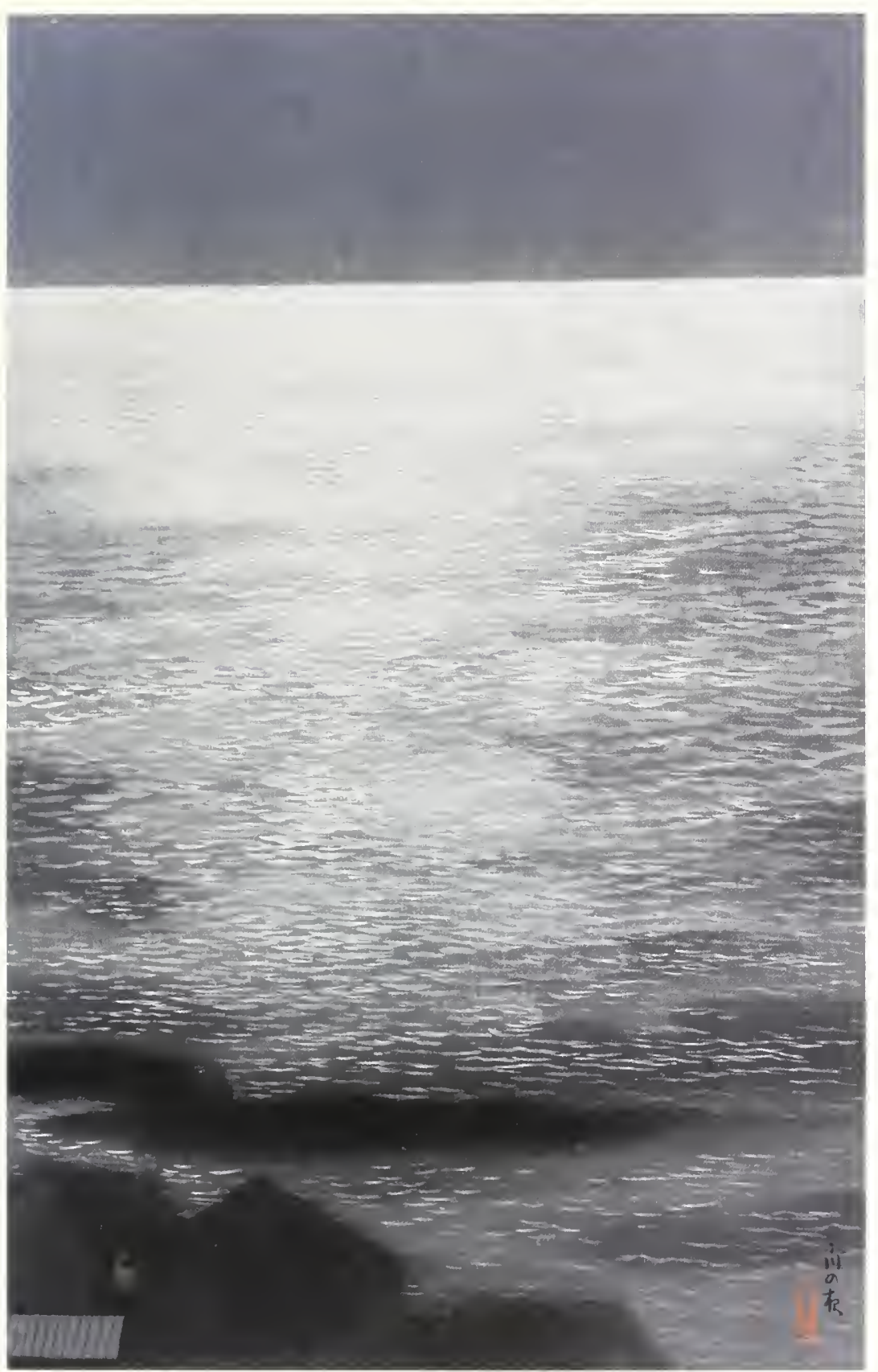

NEGORO RAIZAN (B. 1877)

Shinagawa in the moonlight

Japan, 1922

Woodblock print; ink and colour on paper

$37.4 \times 24 \mathrm{~cm}$

Arthur M. Sackler Gallery, Smithsonian Institution, Washington D.C.; Robert O. Muller Collection

Inv. no. \$2003.8.1594

Raizan's depiction of moonlight on Tokyo Bay at Shinagawa is one of the most distinctive and startling prints produced by any Shin-hanga artist.

The print contains multiple references to techniques being concurrently explored by Japanese painters - bold composition, abstraction, obvious references to textile design, and the inclusion of metallic silver pigment - all used to stunning effect. Perhaps no other print artist of the modern era, with the exception of Kobayashi Kiyochika, so successfully challenged the inroads made by photography. Frustratingly, there is almost no biographical information about this innovative designer. 
KOBAYASHI KIYOCHIKA (1847-1915)

View of Takanawa Ushimachi

Japan, 1879

Woodblock print; ink and colour on paper

$20.8 \times 32.2 \mathrm{~cm}$

Arthur M. Sackler Gallery, Smithsonian Institution, Washington D.C.; Robert O. Muller Collection

Inv. no. $\$ 2003.8 .1179$

Kiyochika's life spanned the entire Meiji period (1868-1912), a time of intense industrialization. As a printmaker, he recorded and interpreted the ways in which Western technologies were absorbed into Japan's traditional landscape. Indeed, he became especially well-known for his images of the night sky as it was transformed by man-made light. In this print, the novelty of the American made locomotive is the ostensible focus, but the real subject is the way in which multiple sources of light - manmade and natural - interact within an otherwise darkened atmosphere.
KOBAYASHI KIYOCHIKA (1847-1915)

\section{Fireworks at Shinobazu Pond}

Japan, 1881

Woodblock print; ink and colour on paper

$20.3 \times 31.2 \mathrm{~cm}$

Arthur M. Sackler Gallery, Smithsonian Institution, Washington D.C.; Robert O. Muller Collection

Inv. no. \$2003.8.1197

Images of fireworks were a standard element in a pre-modern printmaker's repertoire. In that sense, Kiyochika fulfills his audience's expectations for traditional subject matter. He extends the boundaries of that tradition, however, by drawing the viewer into the same intimate perspective experienced by the spectators crowded on the periphery of the image. Moreover, Kiyochika pushes the dark tonalities of the print to an extreme that would not have been found in earlier $19^{\text {th }}$-century designs. Viewers look out toward Benten Shrine which is sited in the middle of Shinobazu Pond. This effective, slightly melancholic essay about the reception of modernity is ironically undermined by the fact that the red temple gate is a concrete reproduction on a small island approached by a causeway in Ueno Park, Tokyo. 

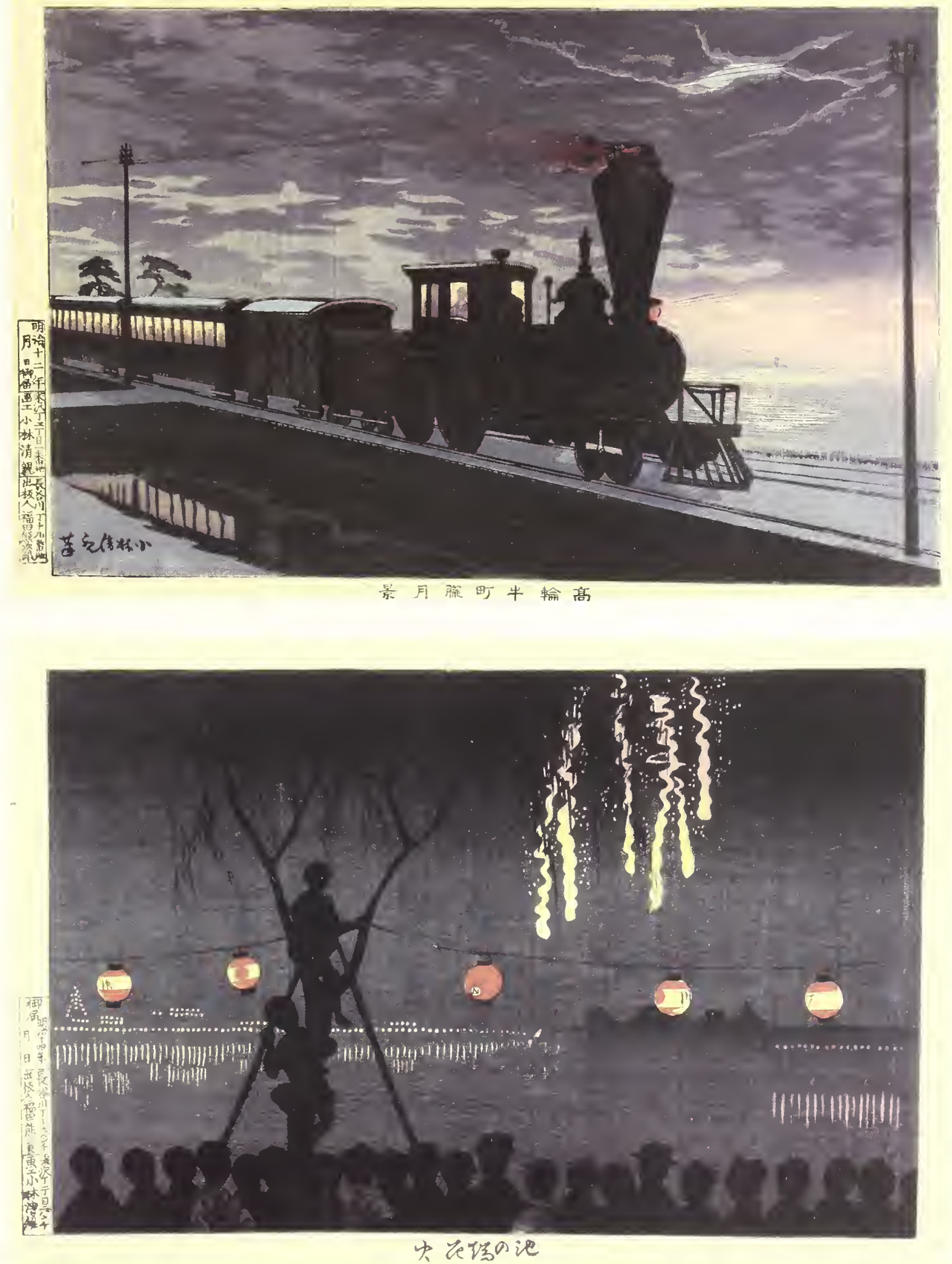
KOBAYASHI KIYOCHIKA (1847-1915)

Tarō Inari Shrine at the Asakusa rice fields

Japan, ca. 1877-81

Woodblock print; ink and colour on paper

$19 \times 28.3 \mathrm{~cm}$

Arthur M. Sackler Gallery, Smithsonian Institution,

Washington D.C.; Robert O. Muller Collection

Inv. no. $\$ 2003.8 .1174$

Throughout the $19^{\text {th }}$ century, Tarō Inari Shrine was a popular Shinto destination for cult worshippers who sought miraculous healings. By the late 1870s, however, the site had become a wasteland, populated only by a lone gate and some wretched buildings. In this profoundly melancholy print, Kiyochika relies on the strong gradations of tone from the foreground to the distance, the stark architecture of the haunting torii gate, which lingers like a gaunt relic, and the severe contrast between the natural and man-made worlds. It is an unusual composition for Kiyochika, who typically populated his landscapes with human figures.

KAWASE HASUI (1883-1957)

Matsushima in the moonlight

Japan, 1919

Woodblock print; ink and colour on paper

$16.8 \times 23.2 \mathrm{~cm}$

Arthur M. Sackler Gallery, Smithsonian Institution,

Washington D.C.; Robert O. Muller Collection

Inv. no. 52003.8 .568

Celebrated in painting and poetry, the panoramic Matsushima Bay at Sendai, on the Pacific coast north of Tokyo, is studded with two hundred sixty pine-covered islands. It was a natural thematic choice in Hasui's quest to interpret well-known sites in Japan. One of his early successes at evoking atmospheric qualities, this landscape has a naive charm. Here, indicators of mood - island, water, and moon - while effective, are still treated as isolated units. They would require his later developed skills before they would be fused by a tactile quality of atmosphere. At this stage, the artist was still in search of how to describe a pervasive medium - or atmosphere - within which these elements could be more closely joined.
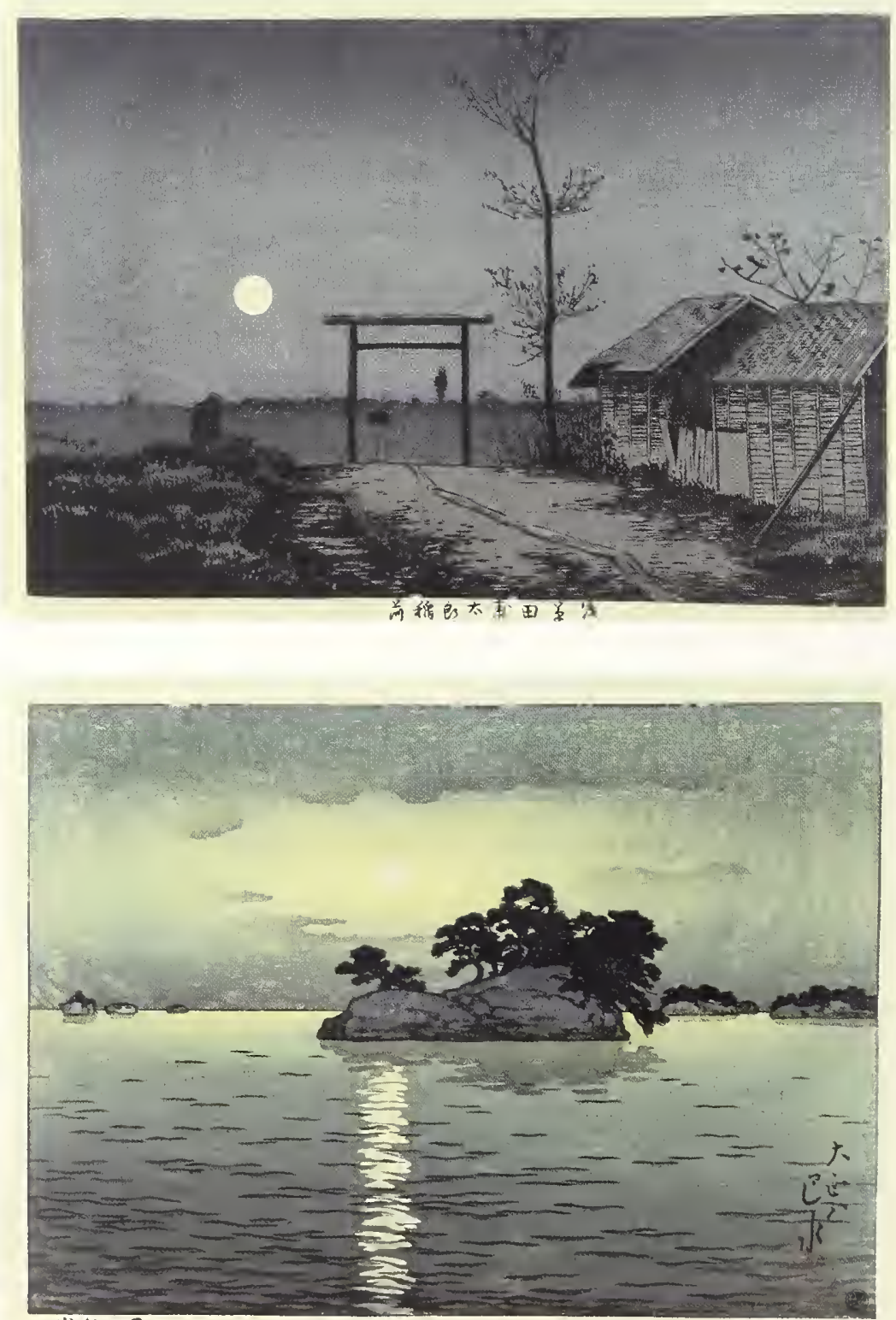

岁稆9月 


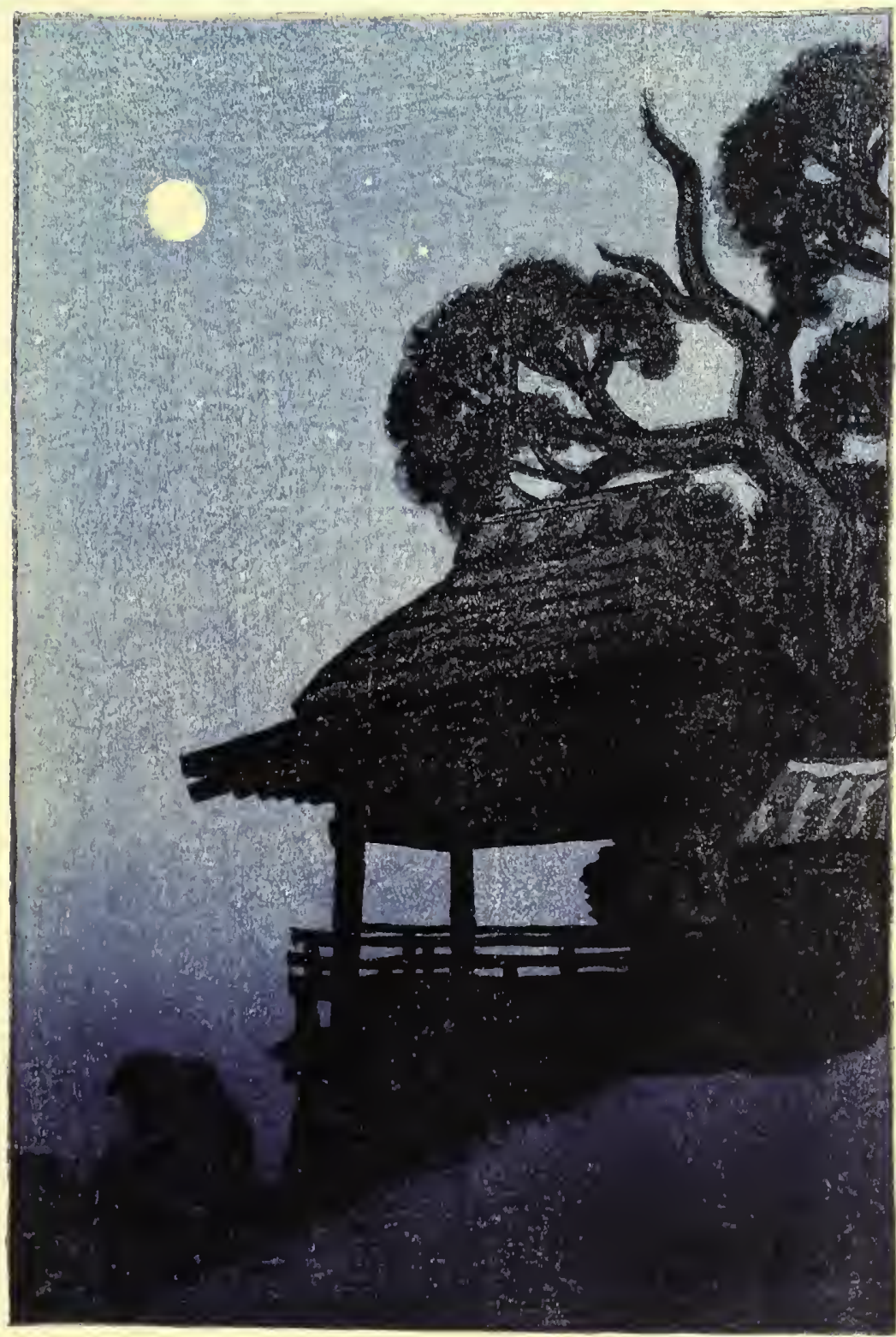

ITŌ SHINSUI (1898-1972)

Full moon at Ishiyama

From the series "Eight views of Ōmi" (Ōmi hakkei)

Japan, 1917

Woodblock print; ink and colour on paper $29.9 \times 20 \mathrm{~cm}$

Arthur M. Sackler Gallery, Smithsonian Institution, Washington D.C.; Robert O. Muller Collection Inv. no. \$2003.8.274

A new generation of $20^{\text {th }}$-century print artists faced the challenge of providing fresh and provocative views while still delivering the expected emotional resonance of the traditional "eight views" genre. Eight views of Ōmi - sites around Lake Biwa, to the east of Kyoto - mimicked the ancient Chinese convention of the eight views of the Xiao and Xiang rivers. Although Shinsui was eventually celebrated for his elegant studies of women, this landscape proved seminal and influential among his peers, as well as with artists of later generations. Shinsui abandoned the precise, recognizable iconography typical of earlier renderings of this site and chose a bold, minimalist design emphasizing the relationship between the light from the moon and the umbral forms of the gnarled tree and temple pavilion. 


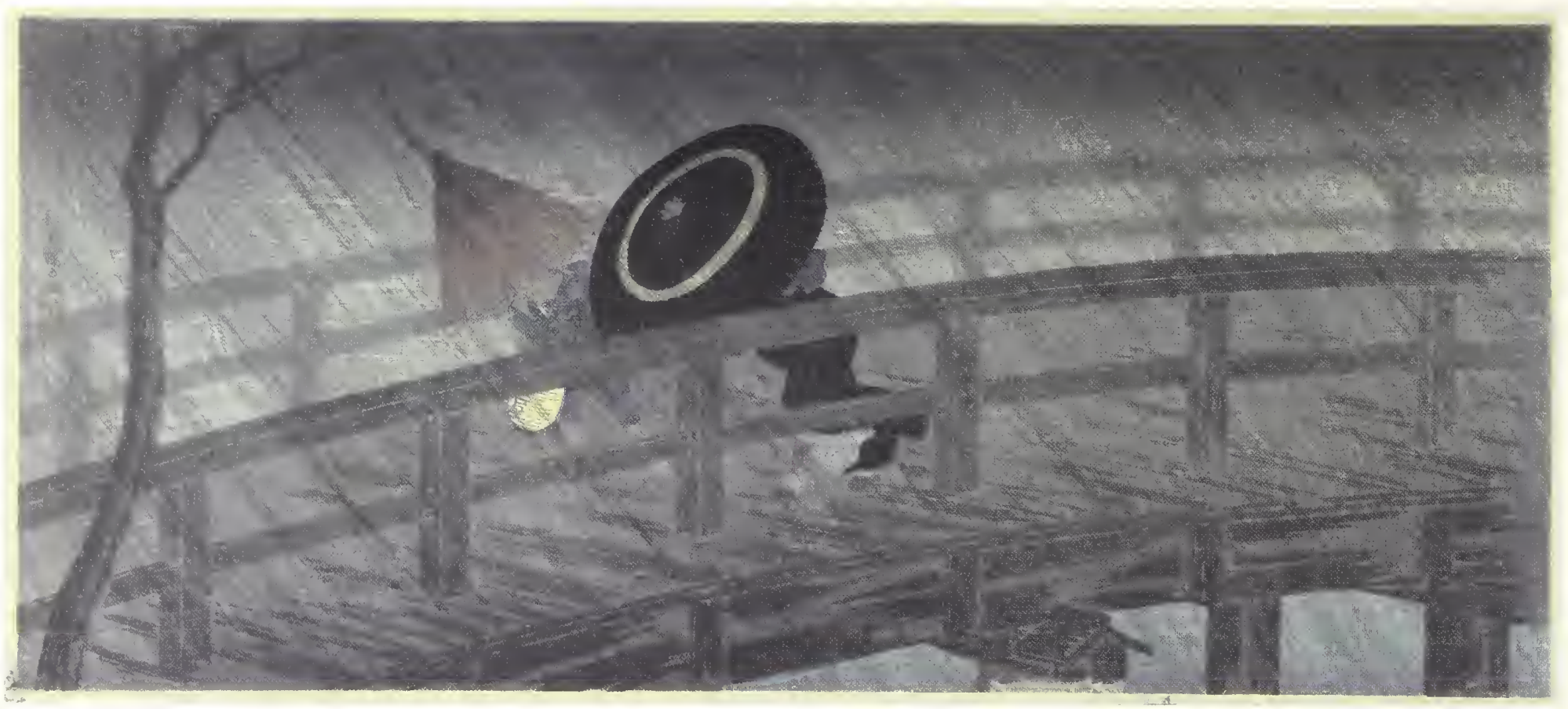

TAKAHASHI SHŌTEI (HIROAKI) (1870-1945)

Izumi Bridge, rainy night

Japan, ca. 1932

Woodblock print; ink and colour on paper

$16.5 \times 37.5 \mathrm{~cm}$

Arthur M. Sackler Gallery, Smithsonian Institution, Washington D.C.; Robert O. Muller Collection

Inv. no. $\$ 2003.8 .2331$

Shōtei alludes to the $19^{\text {th }}$-century bridge-in-the-rain genre. Several aspects, though, distinguish this print from its antecedents and place it firmly in the modern era. For instance, Shōtei concentrates the composition with a tight focus on the two figures and a cropped view of the bridge. His interest in diffusing the lantern light through a dense atmosphere bespeaks a modern approach to the traditional print medium. Izumi Bridge, which crosses over the Kanda River in Tokyo, was originally constructed out of wood. Roughly thirty years before Shōtei produced this image, the bridge had been rebuilt as an arched, steel structure. Shōtei, however, favoured a romantic memory of a bygone Tokyo. 
UEHARA KONEN (1878-1940)

\section{Dōtonbori, Osaka}

Japan, 1928

Woodblock print; ink and colour on paper $36.4 \times 24 \mathrm{~cm}$

Arthur M. Sackler Gallery, Smithsonian Institution, Washington D.C.; Robert O. Muller Collection Inv no. $\$ 2003.83101$

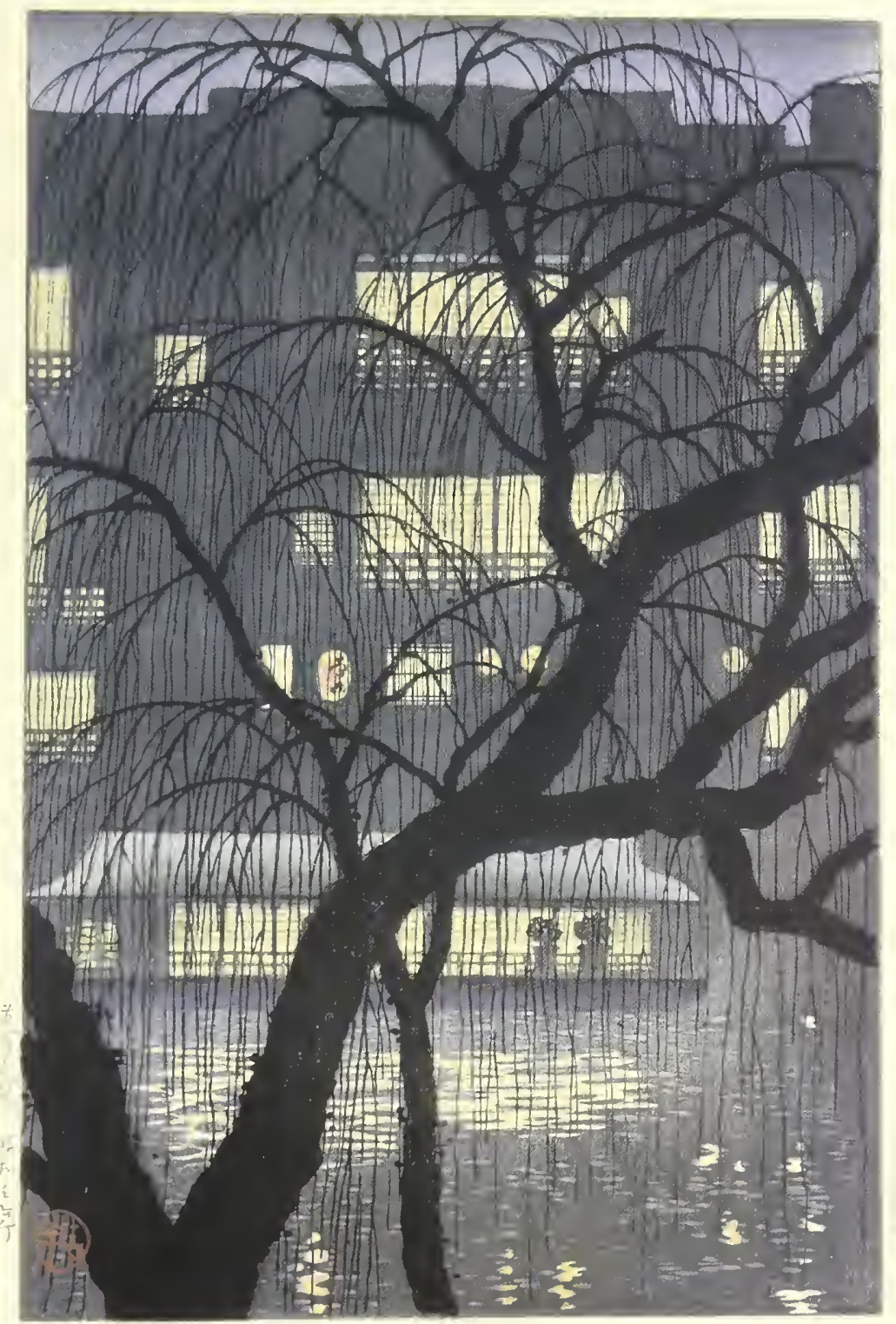

The scant biographical information on Konen indicates he produced woodblock prints in the traditional Ukiyo-e style for Kobayashi Bunshichi (1864-1923), an art purveyor in Tokyo with an extensive clientele in the United States. Watanabe Shōzaburō, also originally employed by Kobayashi and later the founder of the Shin-hanga movement, took in Konen after Kobayashi's death during the devastating 1923 earthquake. In this, perhaps Konen's most successful print, the artist has fully internalized the new directions pioneered by Watanabe. The atmospheric night scene of entertainment along the waterways of Dōtonbori, Osaka, incorporates classic Shin-hanga elements - dark foreground, complex layerings of light and line, and subtle gradations of colour. 
CREATURES

REAL AND IMAGINED 
Reverence for the natural world and its potential for insight into the human condition is a constant theme in Japan's artistic history. Flora and fauna provide mirrors - even clues - to the workings of the human soul. More often than not, depictions of animals and birds paid heed to the preternatural quality of the creatures, as if they possess a knowing spirit. Similarly, the seasons - whose various permutations are categorized and subcategorized by the lapanese to an almost microscopic degree of observation - are similarly endowed with spiritual import. The many moods of the changing seasons inspire artistic meditations on the fleeting nature of existence.

Artists responded to the natural world with verisimilitude, caricature, cartoon, and painterly evocation. In their choices of subject, Shin-hanga artists mined a tradition several millennia old, using the natural world as a guide to the human soul. Whether by overt mimicry of human activity or merely by a subtle, suggestive glint of an eye or tilt of a head, animals were endowed with an inner attitude and knowing spirit fully sympathetic to the range of human aspirations and follies. In Japan the traditional "bird and flower" prints never attained the level of popularity enjoyed by those of the theatre or beautiful women. Nonetheless, several Shin-hanga artists dedicated their careers to the world of birds and flowers - chief among them, Ohara Koson, whose prints were widely distributed in the Western market. 


\section{Cat with mouse}

Japan, ca. 1870

Woodblock print; ink and colour on paper

$37.5 \times 25.1 \mathrm{~cm}$

Arthur M. Sackler Gallery, Smithsonian Institution,

Washington D.C.; Robert O. Muller Collection

Inv. no. 52003.8 .493

Kyōsai here presents a scruffy feline hoisting its new catch as if to examine it in the light of a full moon. The artist's eye for gruesome details was often tinged with slightly perverse humour. Always attuned to the telling details of life's miscellany, Kyōsai was able to distil the physical essence of his subject with a masterful economy of line.

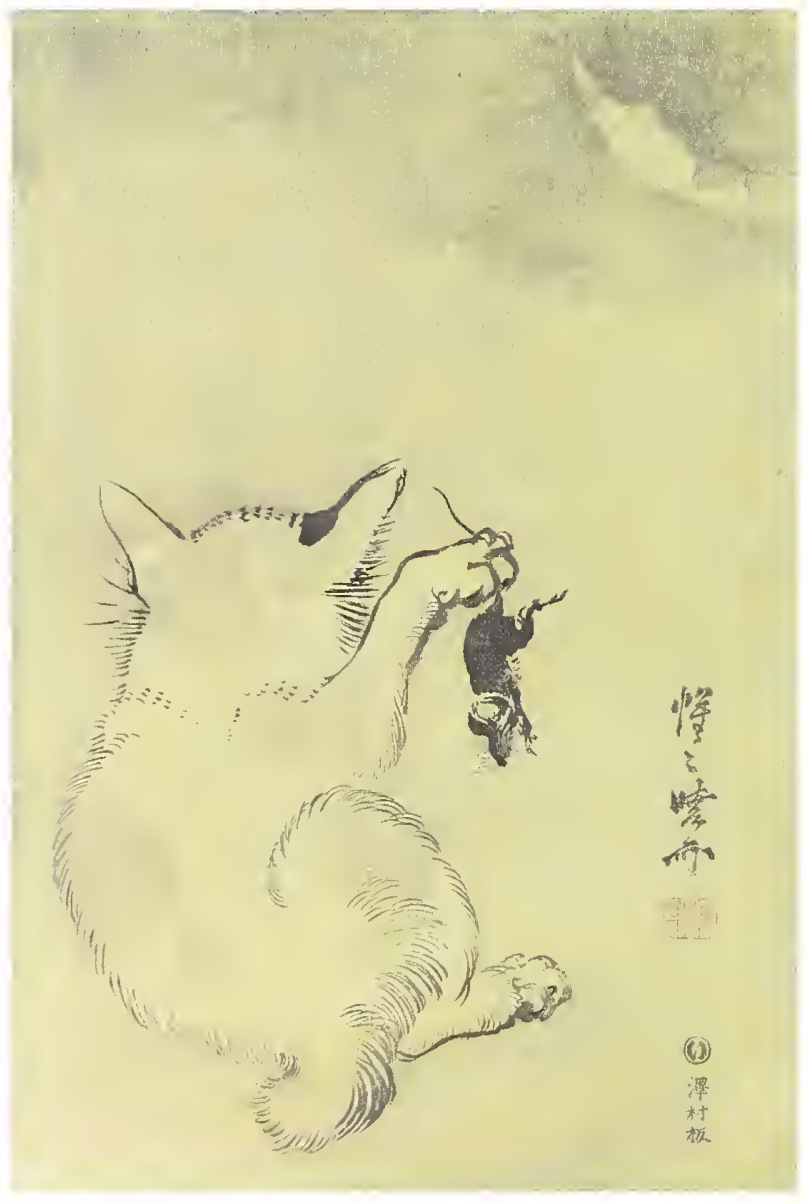

KOBAYASHI KIYOCHIKA (1847-1915)

\section{Cat with lantern}

Japan, ca. 1877

Woodblock print; ink and colour on paper

$30.7 \times 43.5 \mathrm{~cm}$

Arthur M. Sackler Gallery, Smithsonian Institution,

Washington D.C.; Robert O. Muller Collection

Inv no $\$ 200381151$

The popular cat-and-mouse genre was a staple of Japanese $19^{\text {th }}$. century print artists, but Kiyochika's interpretation is decidedly macabre, as a cat has trapped a rat within a burning paper lantern. Seeking an exit, the rat has poked his snout through the charred paper. True to his signature interest, Kiyochika illuminates the scene with a single source - a candle inside the lantern. The artist catered to a growing market for Westernstyle oil paintings by providing the same effects in the much less expensive print format. Indeed, the painterly qualities seen in this print caused it to be mistakenly entered among a group of oil paintings displayed at the First National Industrial Exhibition in Tokyo in 1877.

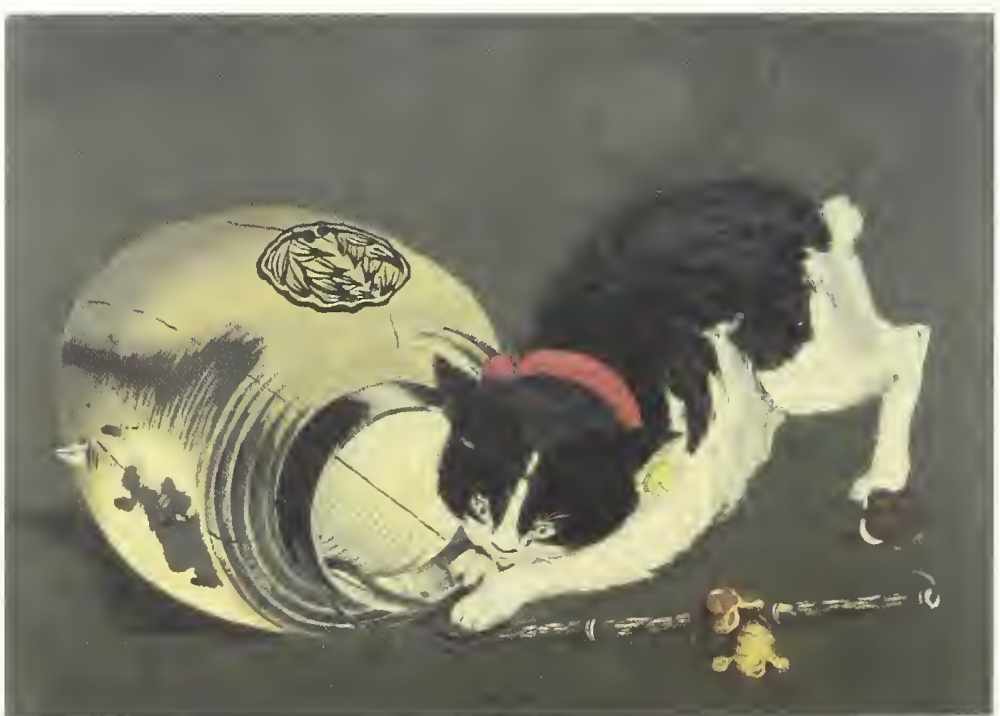


WATANABE SEITEI (1851-1918)

Praying mantis near a branch

From the series 'Seitei's flowers and birds' (Seitei kachō)

Japan, 1916

Woodblock print; ink and colour on paper

$20.8 \times 31.8 \mathrm{~cm}$

Arthur M. Sackler Gallery, Smithsonian Institution,

Washington D.C.; Robert O. Muller Collection

Inv no. \$2003.8.3277

The genre of "bird and flower" prints (kachö-ga) was more embracing than the literal term suggests. Japanese assimilation and adaptation of renderings of the natural world, particularly in the bird-and-flower genre, has a history extending back at least to the $8^{\text {th }}$ century. From the $17^{\text {th }}$ century onward, in imitation of European encyclopaedists' learning, the broader "study of the natural world" (honzō gaku) gained in popularity. Here, Seitei presents a carefully and accurately observed praying mantis, momentarily poised just outside of its natural camouflage. The contrast between the seductive beauty of the flowers and the predatory instincts of the female mantis hints at the artist's wry sense of irony.

TAKAHASHI SHŌTEI (HIROAKI) (1870-1945)

\section{Sweet pea and butterfly}

Japan, 1926

Woodblock print; ink and colour on paper $24 \times 36.2 \mathrm{~cm}$

Arthur M. Sackler Gallery, Smithsonian Institution, Washington D.C.; Robert O. Muller Collection Inv. no. $\$ 2003.8 .2387$

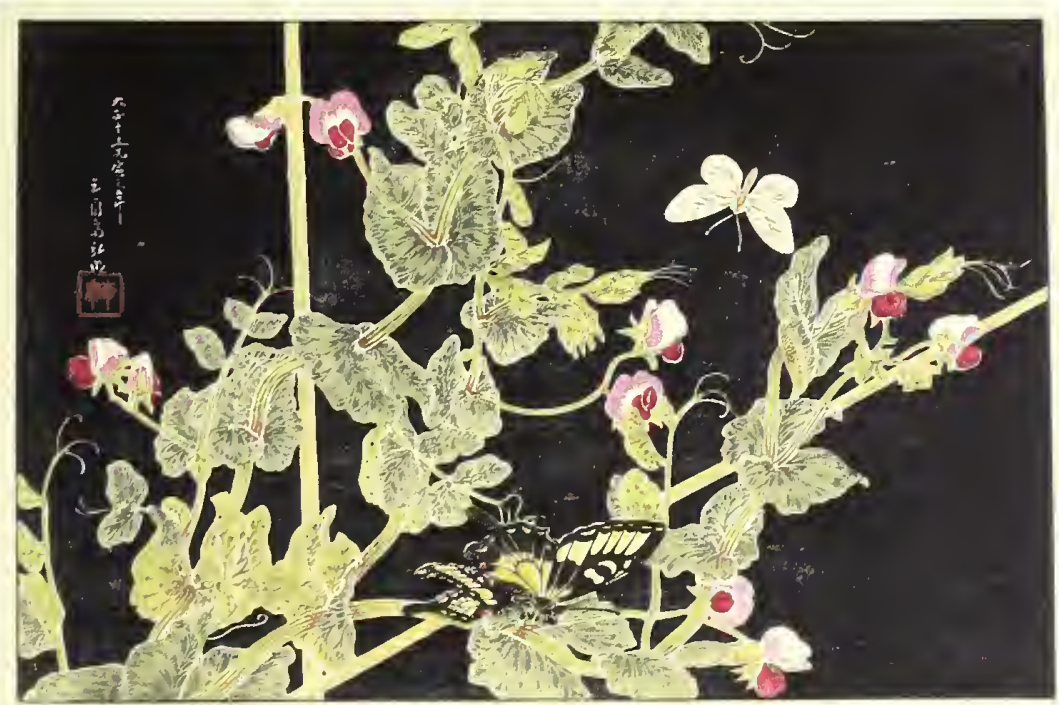

Shōtei designed hundreds of prints - possibly more than any other Shin-hanga artist. In this print, his use of the dramatic black background hints at the influence of and competition with other forms - cloisonné, textile patterns, and drawings on ceramic glaze. Moreover, the dark background intensifies the uncertain source of light that infuses the sweet pea vine as it winds across a trellis. 
Woodblock print; ink and colour on paper

$36.2 \times 24.8 \mathrm{~cm}$

Arthur M. Sackler Gallery, Smithsonian Institution,

Washington D.C.; Robert O. Muller Collection

Inv. no. $\$ 2003.8 .489$

Kyōsai is reputed to have produced as many as two hundred drawings in one day. His most celebrated painting was an inkon-paper rendering of a crow on a branch, an award-winning creation exhibited in 1881 at the Second National Industrial Exhibition in Tokyo. Its success obliged him to satisfy a great demand for similar images. Here, perhaps bored with the public clamour for printed copies of the painting, he achieves the feel of brushwork with an ironic reversal, using the white, un-inked paper to compose the central elements. The bird's eye and the slightest gradation in and around the beak further nuance this print.

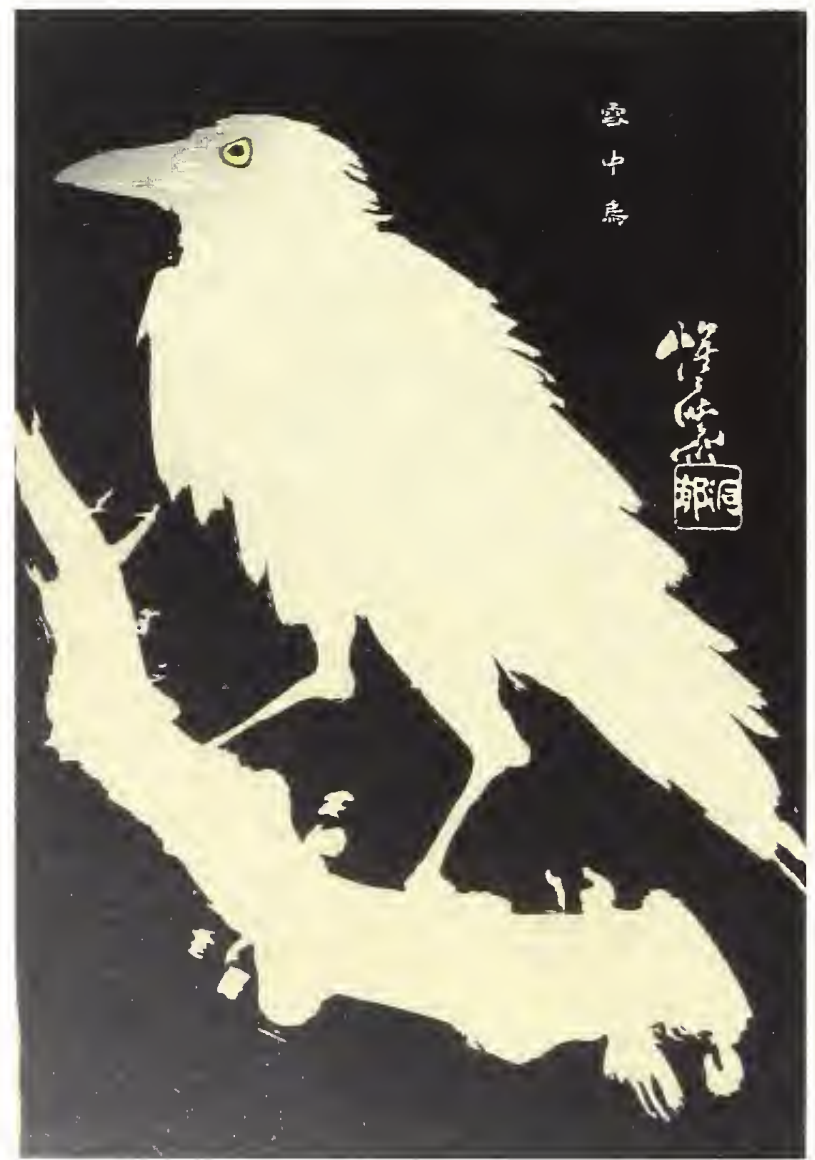

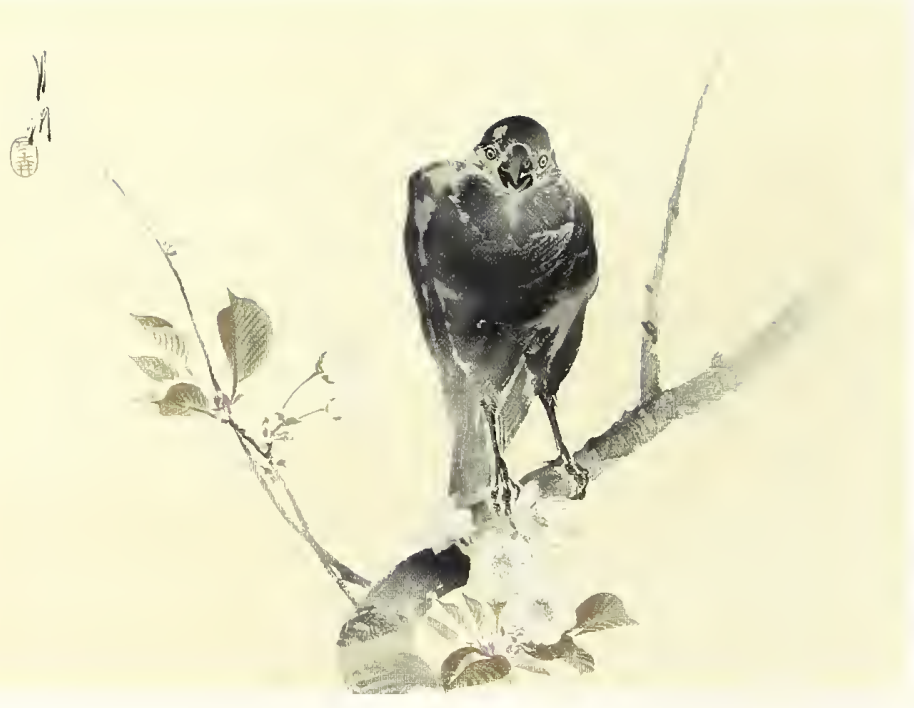

OGATA GEKKŌ (1859-1920)

Crow on a plum branch

From the series 'Twelve bird-and-flower prints'

Japan, 1899

Woodblock print; ink and colour on paper

$24 \times 31.5 \mathrm{~cm}$

Arthur M. Sackler Gallery, Smithsonian Institution,

Washington D.C.; Robert O. Muller Collection

Inv. no. $\$ 2003.8 .1736$

Gekkō was a master of a lyrical painting style that Kyoto artists had much experimented with during the $18^{\text {th }}$ century. This print effectively evokes that same limpid descriptive technique. Translating Gekkō's visual essays into print required an artisan exceptionally skilled at manipulating gradations of pigment with little or no reliance on defining lines. The form of this hunched and slightly querulous crow is the product of a complex series of colour overlays. The branch, leaves, and flowers are elegant, in contrast to the image of the crow, who is portrayed as an old street tough. 
OHARA KOSON (SHŌSON) (1877-1945)

\section{Crow on night cherry}

Japan, ca. 1910

Woodblock print; ink and colour on paper $34.7 \times 19 \mathrm{~cm}$

Arthur M. Sackler Gallery, Smithsonian Institution, Washington D.C.; Robert O. Muller Collection

Inv. no. $\$ 2003.8 .1910$

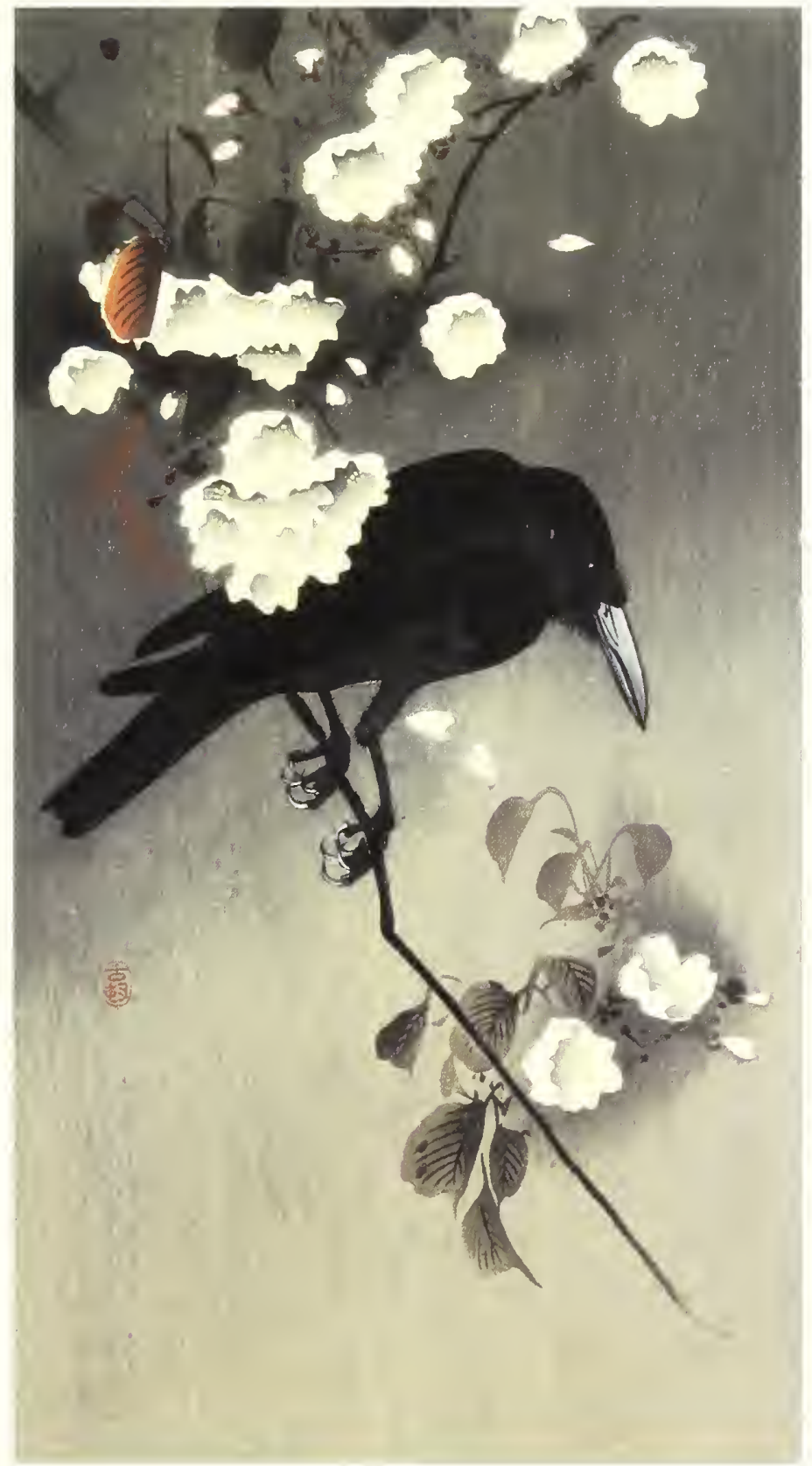

Ohara Koson made a name for himself as an illustrator of scenes from the Russo-Japanese War (1904-05) but found his niche as a master designer of bird-and-flower prints. His representations are most often compositionally spare, featuring the creature and some supporting flora. In this - one of Koson's more successful explorations of contrasts - the weighty form of the crow balances gingerly on a branch of cherry blossoms. The bird's sense of ruffian feistiness is countered by the delicacy of the blossoms. In a similar dynamic, the dark tonalities of the feathers are offset by the radiant blossoms, which seem to reflect the source of a muted, ambient light. 


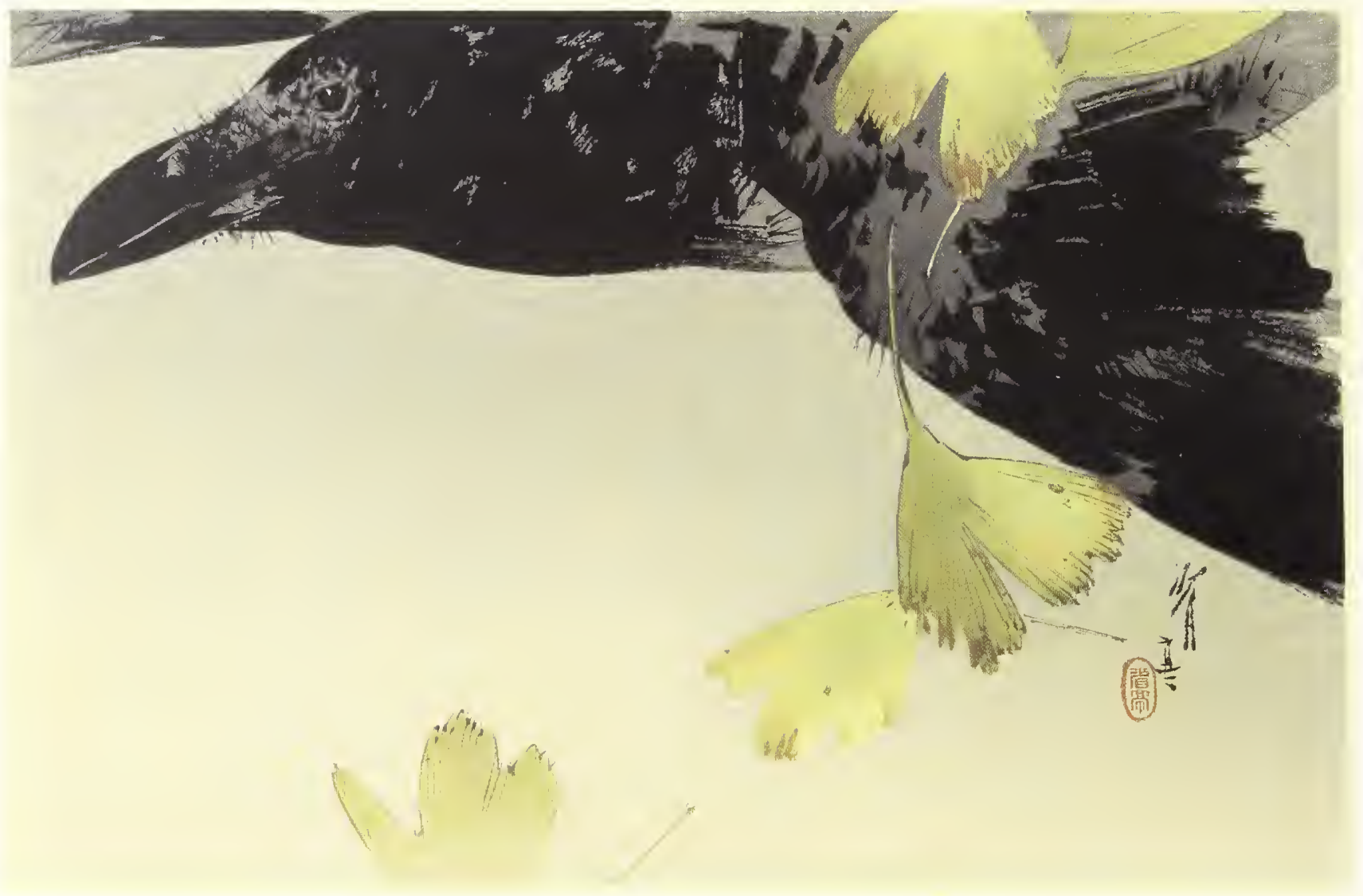

WATANABE SEITEI (1851-1918)

\section{Crow and ginkgo leaves}

From the series 'Seitei's flowers and birds' (Seitei kachō gafu) Japan, 1916

Woodblock print; ink and colour on paper

$20.9 \times 31.7 \mathrm{~cm}$

Arthur M. Sackler Gallery, Smithsonian Institution, Washington D.C.; Robert O. Muller Collection

Inv. no. $\$ 2003.8 .3264$
Seitei, an exceptionally gifted painter who was trained in design, emerged as one of the stars of the 1878 Paris Exposition Universelle. He established himself as a painter of substance, but upon his return from Paris to Japan - and increasingly so throughout his career - he realized that designing for the print form was a more economically plausible endeavour. Those works, including the one seen here, are characterized by a sharp, almost crystalline definition of natural forms. The slightest reserve of white in the crow's eye suggests not only the reflection of the light source but also a hint of personality.

The image itself - the falling ginkgo leaves - evokes a sense of autumn. Seitei daringly crowds the top of the composition with the crow's stark form, allowing the insubstantial ginkgo leaves to provide the visual balance. 


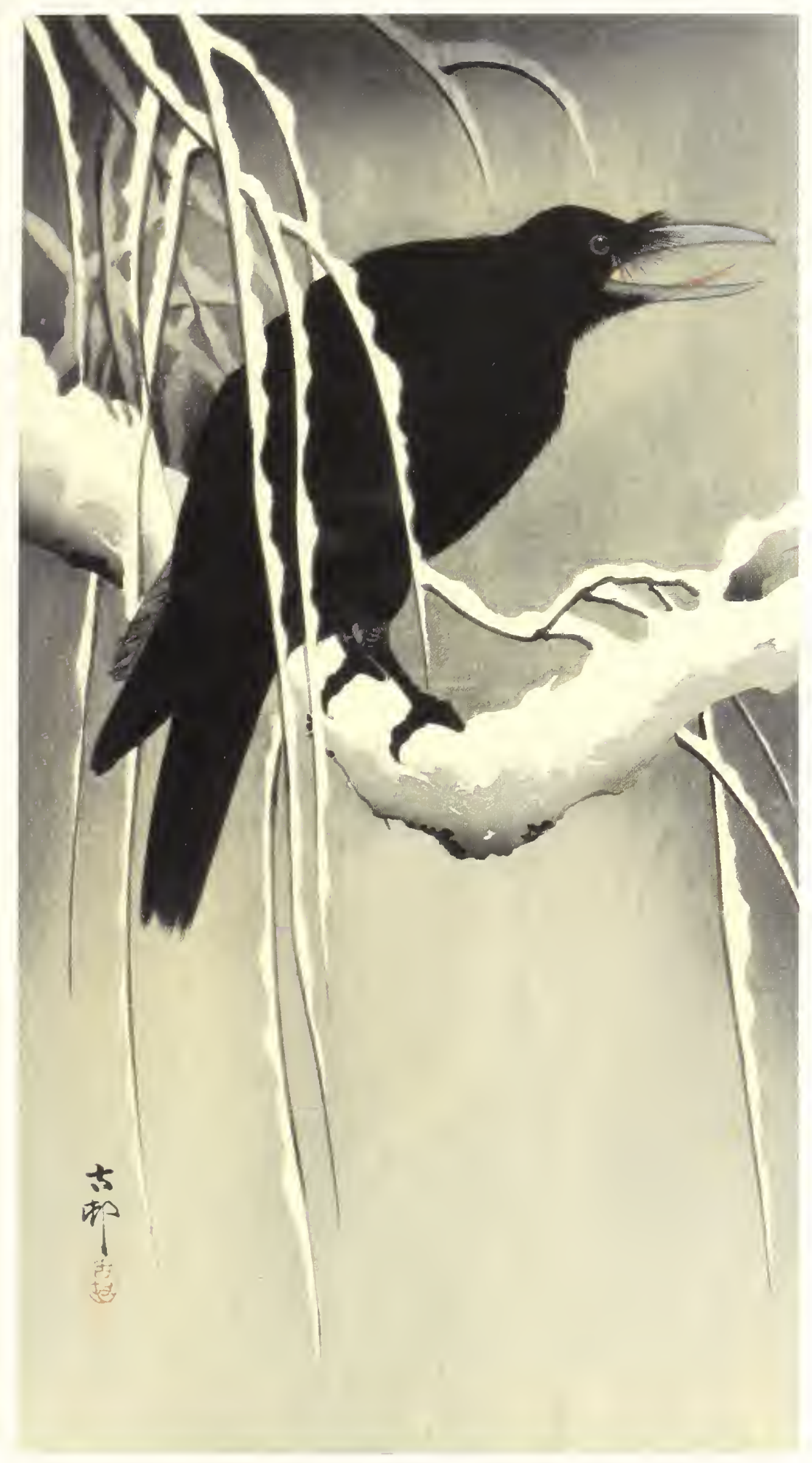

OHARA KOSON (SHŌSON) (1877-1945)

Crow on a snowy bough

Japan, ca. 1913

Woodblock print; ink and colour on paper

$34 \times 19.4 \mathrm{~cm}$

Arthur M. Sackler Gallery, Smithsonian Institution,

Washington D.C.; Robert O. Muller Collection

Inv. no. \$2003.8.1922

What appears at first glance to be a study in black and white is, upon closer inspection, a much more subtle and complex interplay between texture and colour. The black begins to reveal different layers. Carefully positioned accents of colour - the crow's mouth and the artist's seal - punctuate the dense atmospheric effect of the moist, new-fallen snow. 
OHARA KOSON (SHŌSON) (1877-1945)

Fox

Japan, undated

Woodblock print; ink and colour on paper

$34.5 \times 18.8 \mathrm{~cm}$

Arthur M. Sackler Gallery, Smithsonian Institution,

Washington D.C.; Robert O. Muller Collection

Inv. no. $\$ 2003.8 .1845$

A protagonist in many legends and folktales, the fox is often depicted as a trickster, capable of transforming itself, for example, into a beautifully seductive woman - often with comic results. In addition to making use of this tradition, Koson adapts elements from the mid-12 $2^{\text {th }}$ century Chöjü-giga ("Frolicking animals"), a long, horizontal hand scroll painting in which sanctimonious priests are satirically rendered as monkeys, worshippers as foxes, and even the Buddha-image as a frog. From this ensemble, Koson culls a single playful portrait of a fox sporting a lotus-leaf hat.
OHARA KOSON (SHŌSON) (1877-1945)

Frogs

Japan, ca. 1932

Woodblock print; ink and colour on paper

$23.8 \times 33.3 \mathrm{~cm}$

Arthur M. Sackler Gallery, Smithsonian Institution, Washington D.C.; Robert O. Muller Collection

Inv. no. $\$ 2003.8 .2075$

In this playful print Koson alludes to the medieval Chöjū-giga ("Frolicking animals"), a series of hand scroll paintings from the mid- $12^{\text {th }}$ century that established the highest level of comedy and competence in anthropomorphic renderings of animals. While those paintings offer satirical commentary on the foibles of aristocracy, Koson's print simply presents a light-hearted fantasy of frogs engaged in a sumo competition. The leaf here is substituted for the stylized fan usually carried in the contest by an umpire.
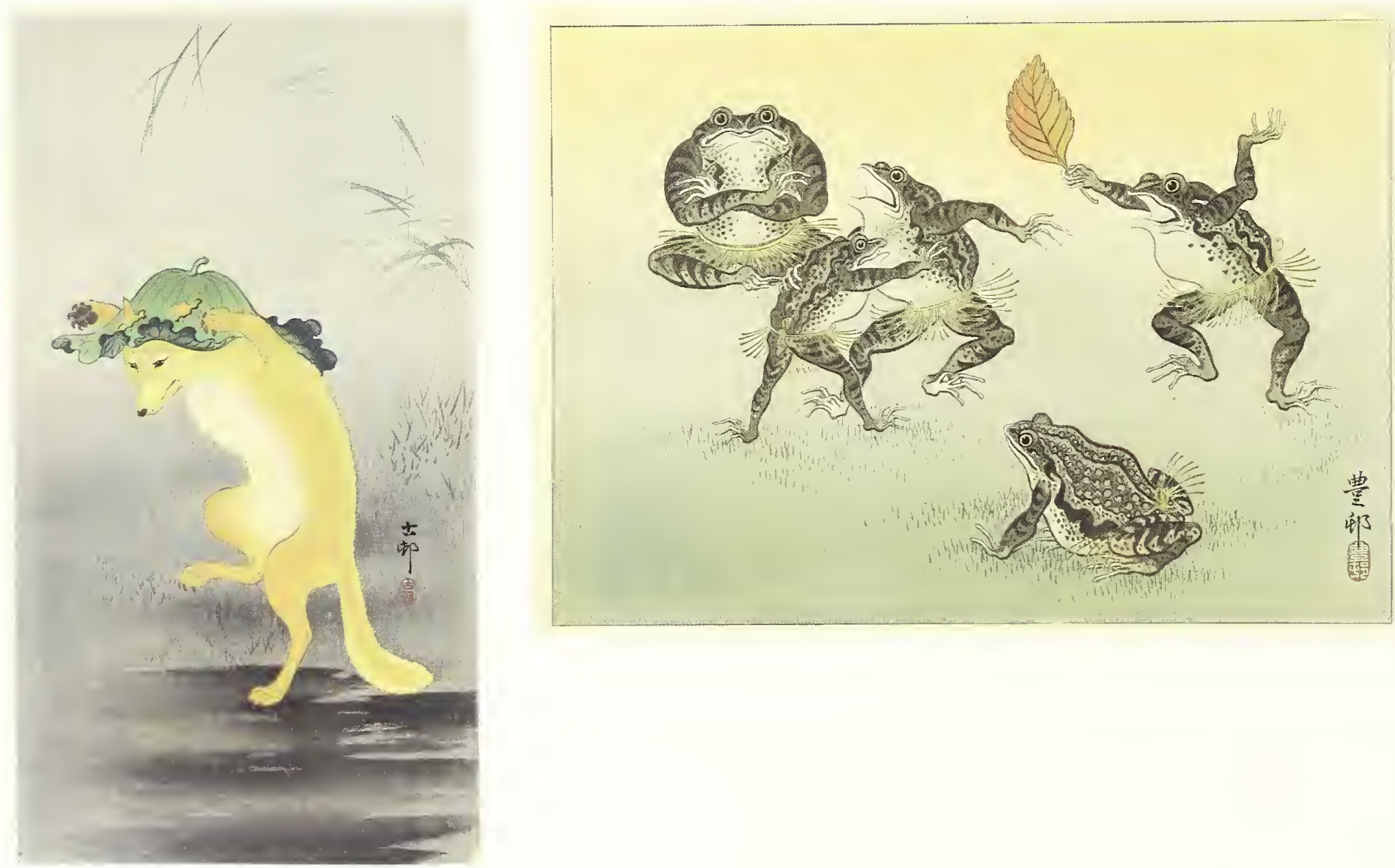

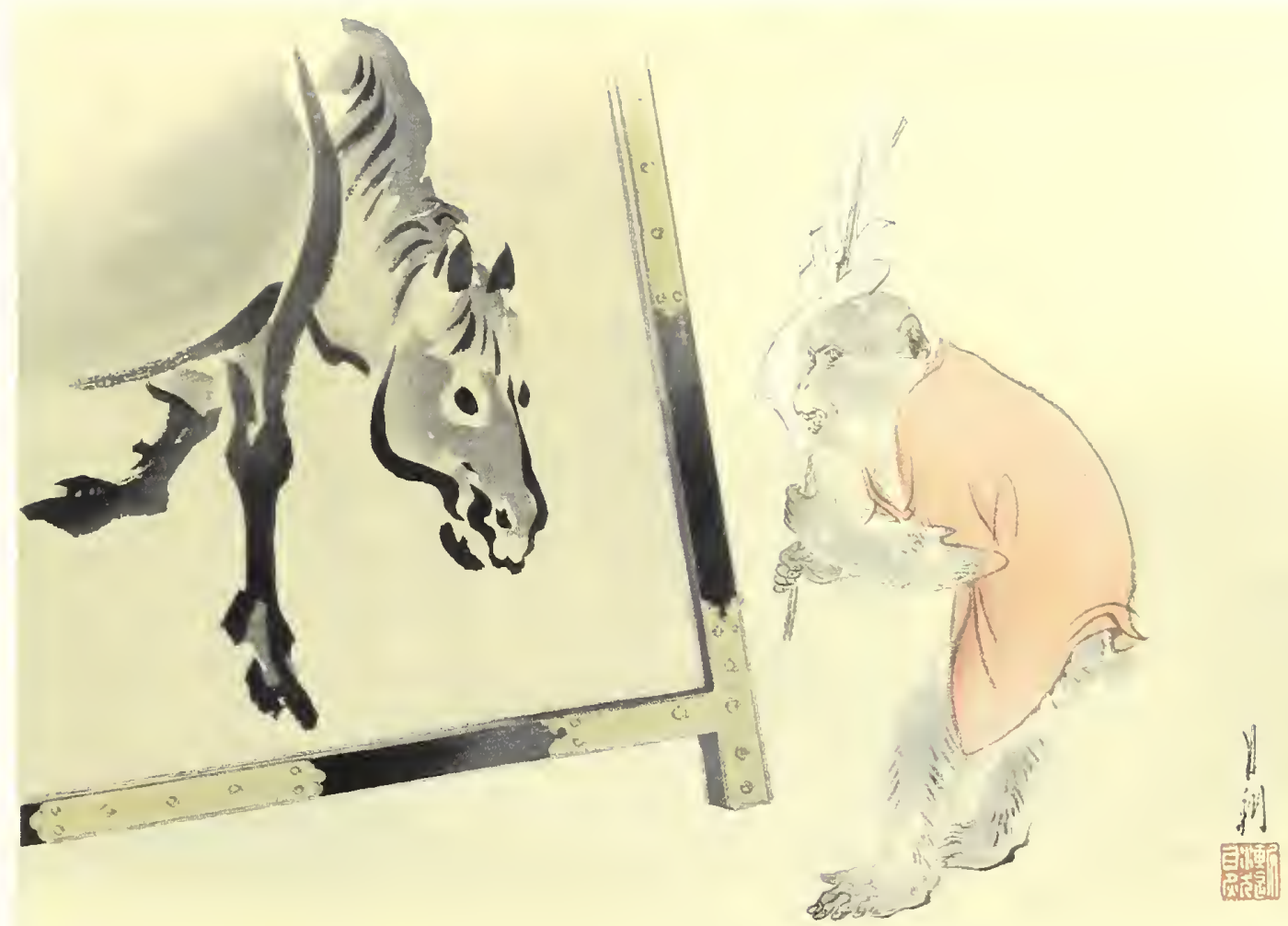

OGATA GEKKŌ (1859-1920)

A monkey and the painting of a horse

From the series 'Twelve bird-and-flower prints'

Japan, 1899

Woodblock print; ink and colour on paper

$23.8 \times 30.2 \mathrm{~cm}$

Arthur M. Sackler Gallery, Smithsonian Institution, Washington D.C.; Robert O. Muller Collection

Inv. no. $\$ 2003.8 .1742$

Gekkō postulates a delightful encounter between a trained monkey and a painted image of a horse. The monkey, a performer in a New Year's entertainment usually offered in shrines, confronts a painted horse on a votive plaque. Bearing a staff affixed with paper streamers, Gekkō's monkey parodies a Shinto ritual gesture for purifying space. Paintings of heightened verisimilitude were sometimes thought to have a magical power that could transform the image into reality, and legends exist about such horses galloping off the wooden plaques. Here the artist suggests that the monkey is waiting for just such a fabulous occurrence. 


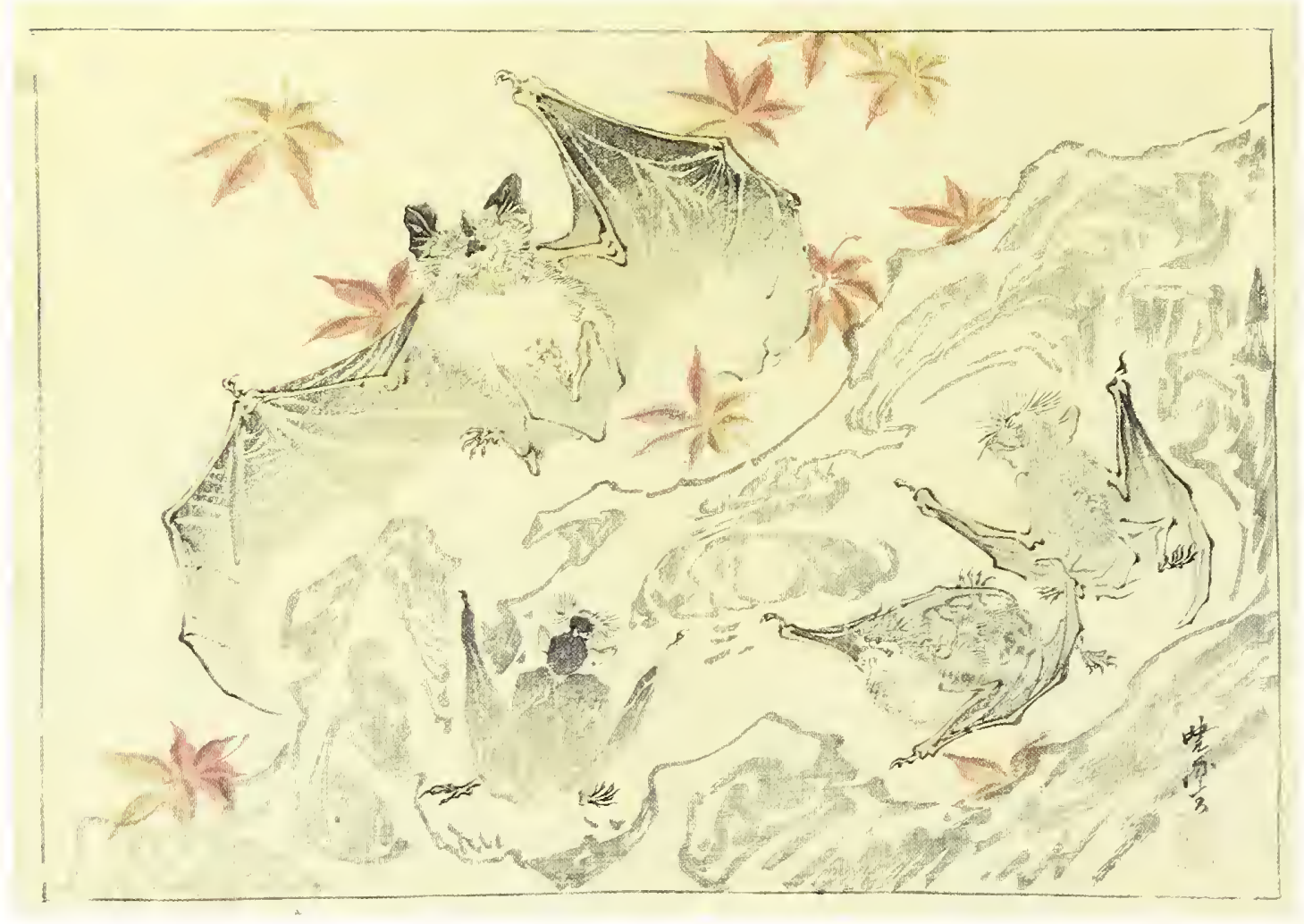

8. KAWANABE KYŌSAI (1831-1889)

Bat

Japan, undated

Woodblock print; ink and colour on paper

$18.5 \times 26.5 \mathrm{~cm}$

Arthur M. Sackler Gallery, Smithsonian Institution,

Washington D.C.; Robert O. Muller Collection

Inv. no. $\$ 2003.8 .492$

In East Asia the bat is considered an auspicious creature. The pronunciation of the Chinese written character is the same as that of the word for "many happiness." In this print, Kyōsai, a gifted cartoonist and caricaturist, achieves a fine balance between a naturalistic rendering and a sense of playfulness. He raises the level above pure anatomical documentation by investing the bats with postures and features that imply personality. 
TAKEUCHI SEIHŌ (1864-1942)

Hare and tortoise

From the series 'Twelve signs of the zodiac' Japan, undated

Woodblock print; ink and colour on paper $33 \times 45.5 \mathrm{~cm}$

Arthur M. Sackler Gallery, Smithsonian Institution, Washington D.C.; Robert O. Muller Collection

Inv. no. $\$ 2003.8 .2478$

Seihō was arguably the greatest modern exponent of a Kyoto painting style that fused a modern sensibility with traditional lyrical representations. This print, through a complex use of bokashi (overlaid gradation of colour), is remarkably successful in approximating the artist's painting style. The scene from the "The Tortoise and the Hare" would have been readily recognizable to any Japanese viewer because Aesop's fables belonged to the first body of Western literature translated into Japanese, at the end of the sixteenth century. These stories, rich with morality lessons, were routinely taught at Japanese schools, especially during the Meiji period (1868-1912). Unlike the commercial designers fully engaged in the Shin-hanga movement, Seihō was first and foremost a painter; his popularity led to the marketing of these reproductions of his painting subjects.

\section{TAKEUCHI SEIHŌ (1864-1942)}

Monkey

From the series 'Twelve signs of the zodiac' Japan, 1940

Woodblock print; ink and colour on paper $38 \times 51.1 \mathrm{~cm}$

Arthur M. Sackler Gallery, Smithsonian Institution, Washington D.C.; Robert O. Muller Collection Inv. no. $\$ 2003.8 .2482$

Seihö was renowned for firsthand and intense scrutiny of his subjects. He reportedly always kept a sketchbook at his side. The artist acquired the monkey seen here - walking upright with a bamboo stick and a leash trailing behind - from a street entertainer to serve as a model. The evocation of this creature translated, as were other Seihō subjects, from painting to print - was achieved by skilful combination of layered wash techniques and limited but strategic use of line in the face, hands, and feet. 
YAMAMURA KŌKA (TOYONARI) (1886-1942)

\section{Pelicans}

Japan, 1926

Woodblock print; ink and colour on paper

$25.2 \times 37.3 \mathrm{~cm}$

Arthur M. Sackler Gallery, Smithsonian Institution,

Washington D.C.; Robert O. Muller Collection

Inv. no. $\$ 2003.83413$

No aspect of life in Tokyo was untouched by the devastating earthquake of 1923. During the long period of recovery, with massive physical reconstruction a central priority, rehabilitation of the city's zoo at Ueno was not neglected. In 1925 the importation of a pair of pelicans - a sign of hope and perhaps frivolity in the long wake of such tragedy - provided inspiration for this Köka study. Close inspection reveals the bold design is enhanced by the use of glistening mica powder in the background and embossing on the birds' feathers. The choice of an exotic subject and the subordination of realism to design concerns indicate the efforts of Kōka and his publisher, Watanabe Shōzaburō, to challenge the conventions of bird-and-flower genre.

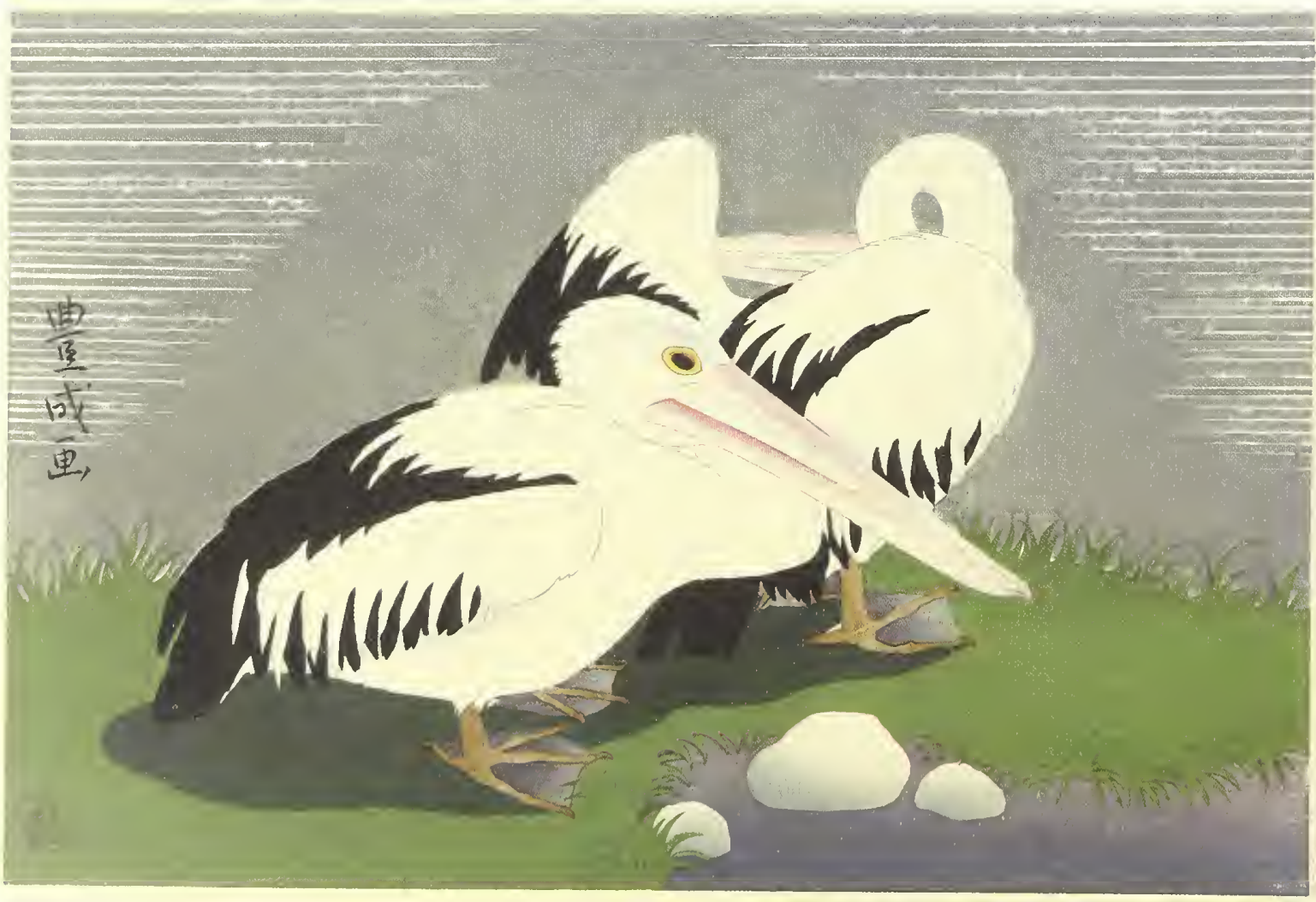




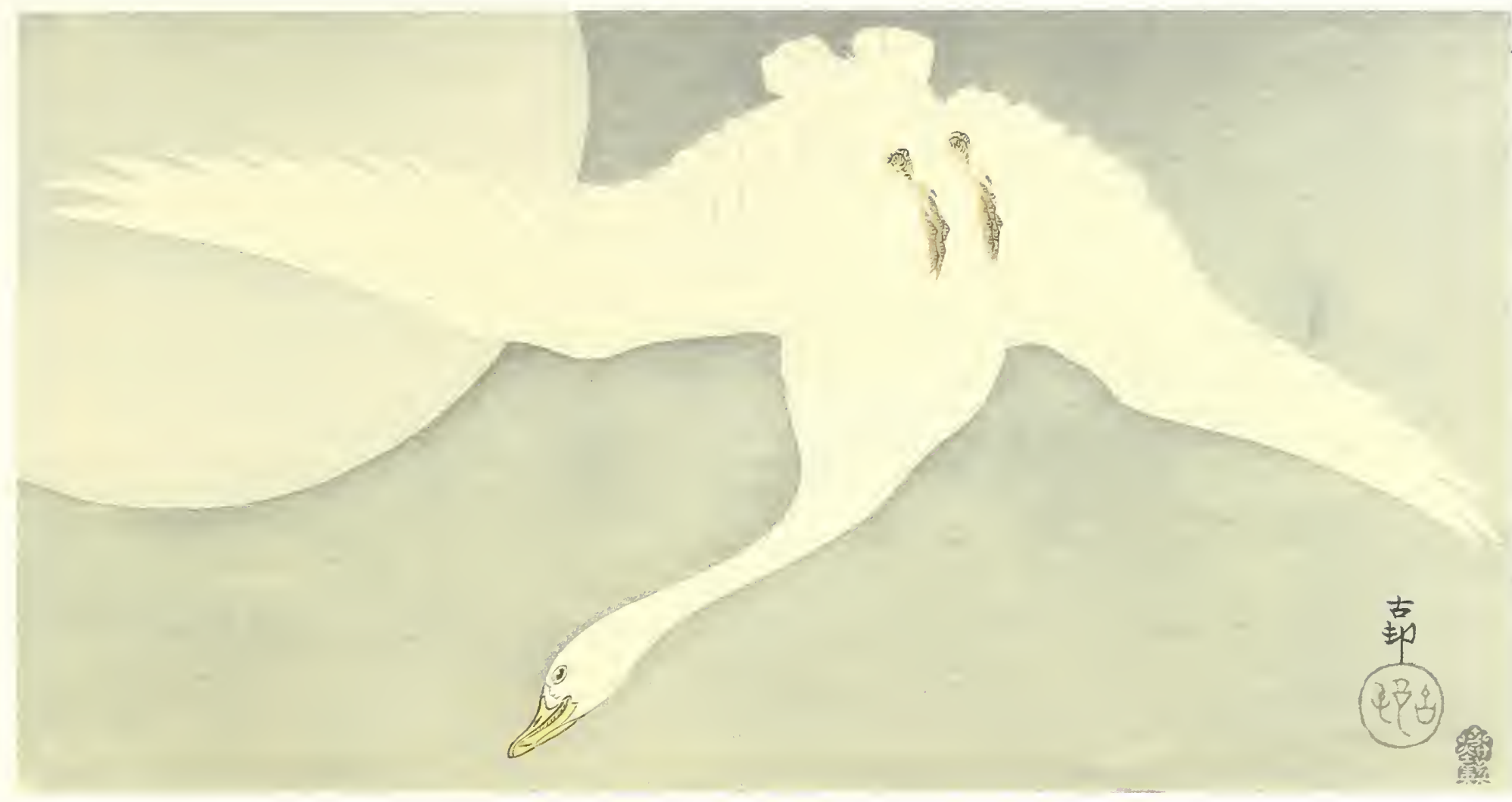

87 OHARA KOSON (SHŌSON) (1877-1945)

White goose by moon

Japan, before 1923

Woodblock print; ink and colour on paper

$18.1 \times 34.8 \mathrm{~cm}$

Arthur M. Sackler Gallery, Smithsonian Institution,

Washington D.C.; Robert O. Muller Collection

Inv. no. $\$ 2003.8 .1940$

Of all of Koson's many depictions of flower and fauna, this is one of his most design-conscious compositions. The artist places the goose in an unrealistic pose, effectively favouring the disorienting qualities of design over the demands of naturalism. 
FUYŌ (1864-1936)

Kingfisher in winter

Japan, after 1923

Woodblock print; ink and colour on paper

$38.1 \times 17.3 \mathrm{~cm}$

Arthur M. Sackler Gallery, Smithsonian Institution,

Washington D.C.; Robert O. Muller Collection

Inv. no. $\$ 2003.8 .1542$

Fuyō was one of a group of young Japanese artists in the late $19^{\text {th }}$ century who benefited from the tutelage of European and American artists resident in Japan. He is said to have studied copperplate etching while working as an assistant to the Italian engraver Eduardo Chiossone (1832-1898) at the printing office of the Ministry of Finance. That training is evident in the absolute precision with which the bird is rendered. The chilly atmosphere of a winter's day is suggested in the graded bands of light that form the background - a colour scheme that complements the bird's feathers. The effect of new-fallen snow is achieved by applying a white powder (gofun) made of ground oyster shells to an adhesive on the paper's surface.

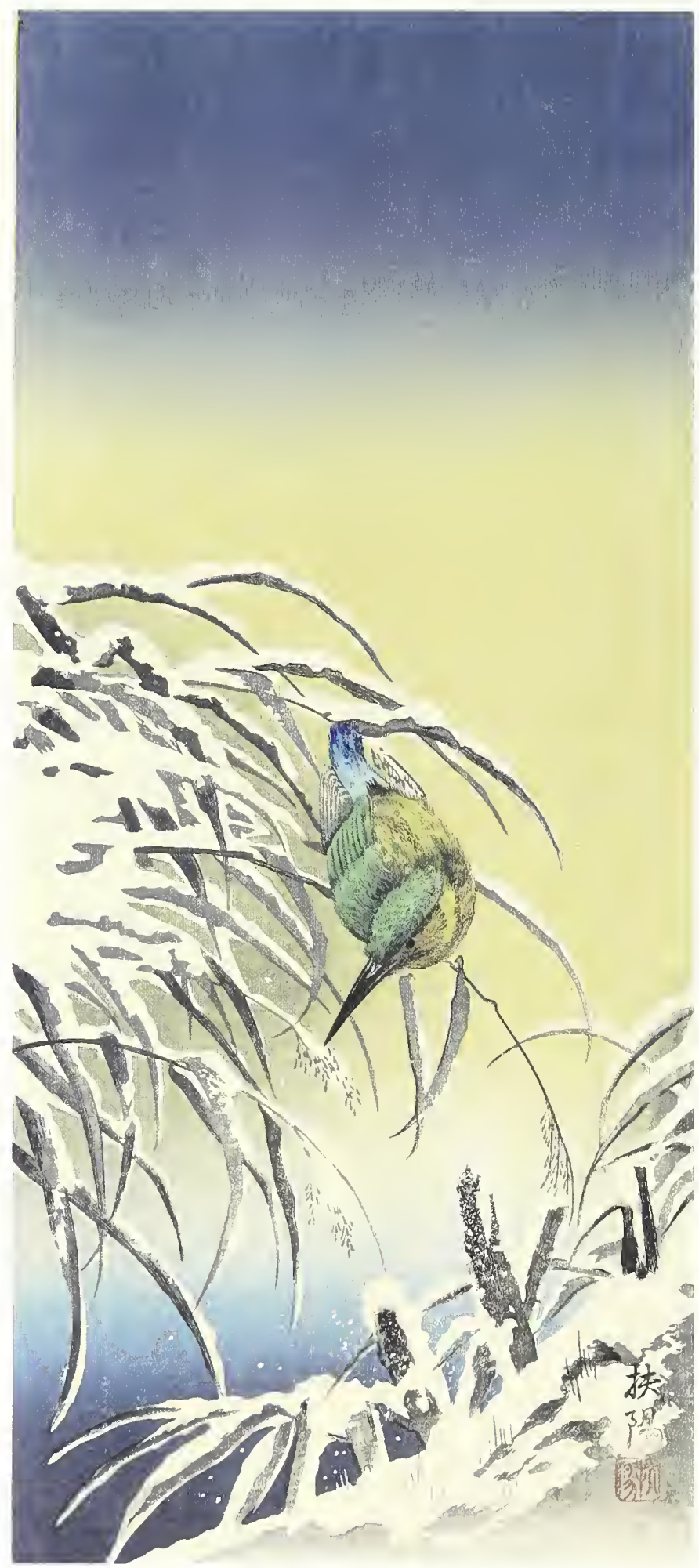




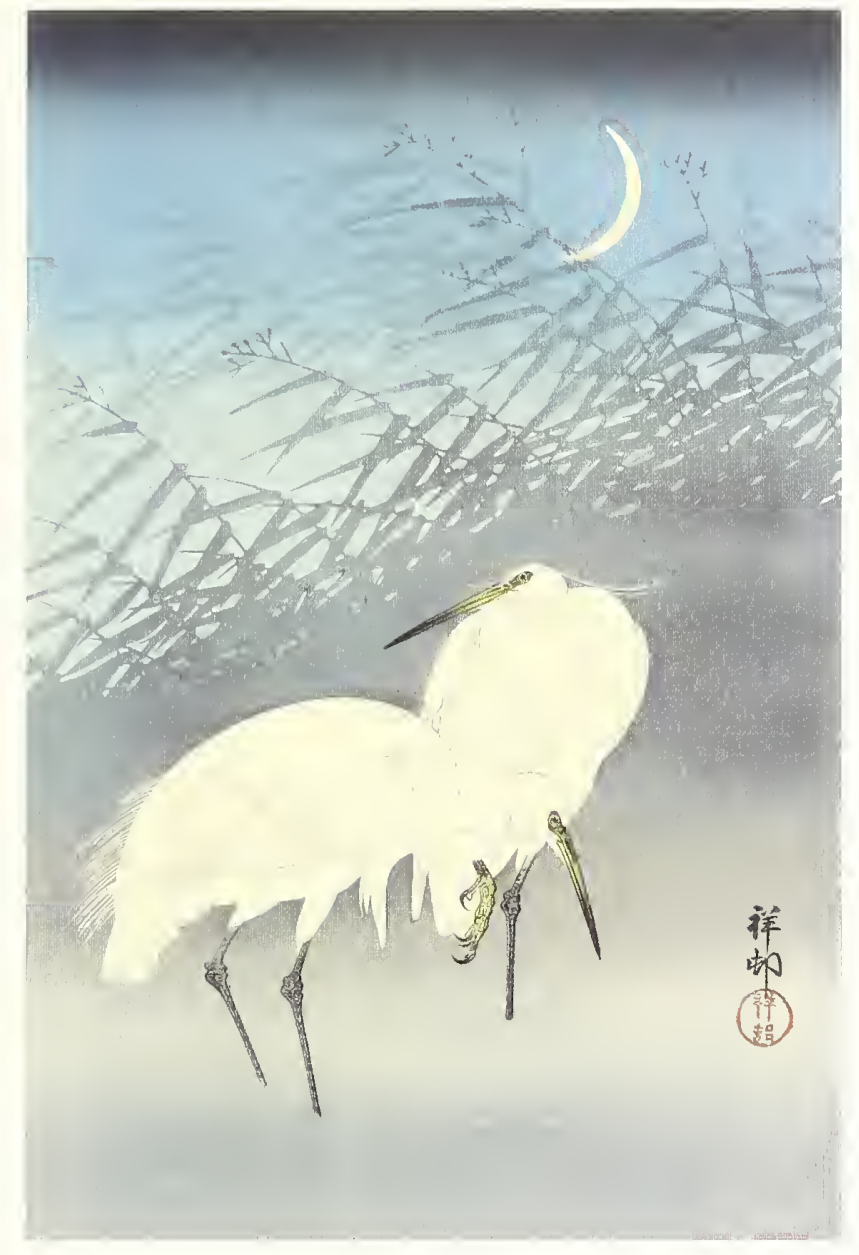

OHARA KOSON (SHŌSON) (1877-1945)

Herons and reeds

Japan, 1926

Woodblock print; ink and colour on paper

$36.2 \times 23.8 \mathrm{~cm}$

Arthur M. Sackler Gallery, Smithsonian Institution,

Washington D.C.; Robert O. Muller Collection

Inv. no. 52003.8.2046

Birds in the heron family are among the most frequently chosen motifs in Koson's oeuvre. Silhouetted against the reeds to enhance the brightness of their plumage, this pair of herons hugs the water's edge in search of small fish. While symbolic of spiritual purity in the Buddhist context, these birds are also venerated for their delicacy and tact - herons are said to leave the stream without disturbing the water or stirring the mud.

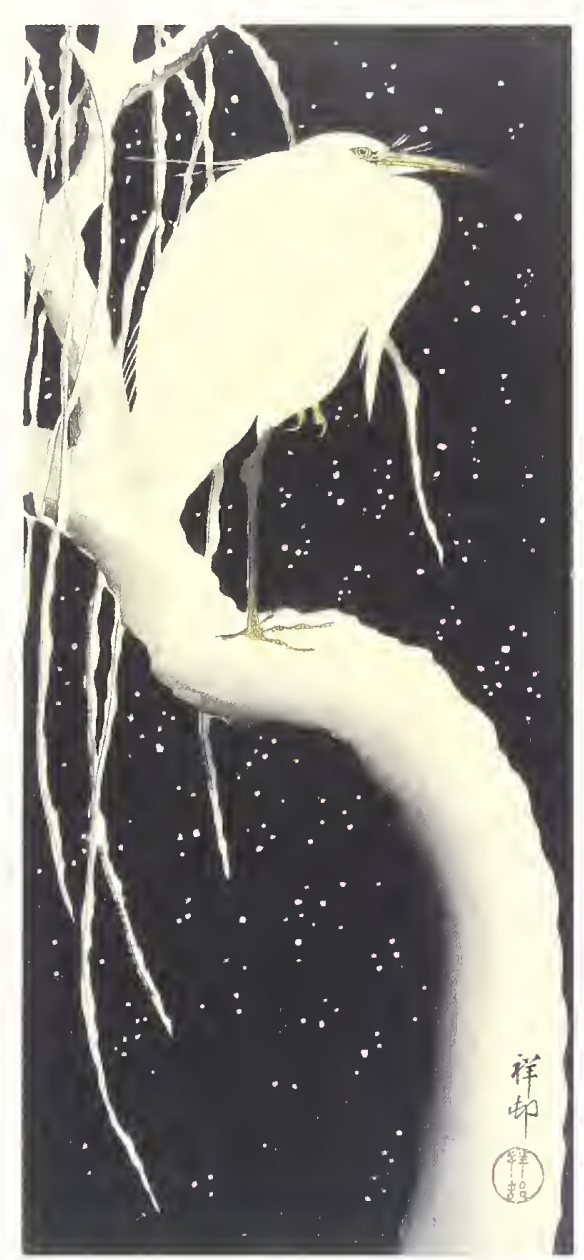

OHARA KOSON (SHÓSON) (1877-1945) White Heron against the night sky Japan, undated

Woodblock print; ink and colour on paper $37.1 \times 16.7 \mathrm{~cm}$

Arthur M. Sackler Gallery, Smithsonian Institution, Washington D.C.; Robert O. Muller Collection Inv. no. 52003.8.2061

The lines of the willow branches accentuate the form of this graceful bird. Owing to its single-legged repose, the white heron is referred to as "the thinker" in the Buddhist context and further admired as a symbol of purity. Here, as frequently in his designs, Koson suggests these ancient associations while offering a naturalistic rendering of the bird. The print is still one of the most sought-after designs by this prolific artist. 


\section{Biographies}

\section{Notes}

The lapanese sequence of family name then personal name is used in all instances. However, in the body of each text, the most familiar usage is provided. For example, Kawase Hasui is commonly referred to by his personal name, Hasui in the body of the note, whereas Yoshida Hiroshi is, in practice, simply called Yoshida. Ito Shinsui, on the other hand, is called Shinsui. Practice rather than firm rule is followed.

The city of Edo changed its name to Tokyo in 1868 when it became the capital of Japan. Kyoto had been the capital for over 1,000 years. Some of the artists discussed here were born in the city when it was called Edo but spent careers in the city named Tokyo.

Diacritical marks in the names have not been used.

\section{Fuyo (1864-1936)}

Very limited biographical information is available. He is said to have studied under the traditional Japanese style painter Kobayashi Eitaku (184390). At various points in his career he used the name Narazaki Eisho, although from around 1916 he began to produce prints primarily for foreign consumption under the name Fuyo. A 1936 sales catalogue released by the print publisher Watanabe Shozaboro offered nine distinct print designs by Fuyo. Fuyo studied copperplate etching techniques when he worked as an assistant to the Italian engraver, Eduardo Chiossone (183298) at the printing offices of the Japanese Ministry of Finance.

\section{Hashiguchi Goyo (1880-1921)}

Goyo was born Kagoshima, at the southern most part of the island of Kyushu. His father, Kanemizu, was a painter in the Kyoto-based Maryuyama-Shijo style that favored soft lyrical depictions. In his late teens, Goyo moved to Tokyo where he studied under the distinguished Japanese style painter Hashimoto Gaho (1835-1908) and learned Westernstyle painting with the French-trained Kuroda Seiki (1866-1924). Goyo graduated at the top of his class in 1905 from the prestigious Tokyo School of Fine Arts. In his very brief career he produced numerous poster designs, book plates and commercial ephemera, but his lasting contribution was a tiny number of sixteen woodblock prints, most of them have the female beauty as subject. For all but one of these prints, Goyo was both the designer and publisher, seeking complete control over the complex production process. His stated goal was to invigorate the flat Japanese print with hints of dynamic figural modelling found in Western art. The results were a subtly beautiful hybrid.

\section{Ishiwata Koitsu (1897-1987)}

Koitsu was a successful textile designer recruited by the print publisher Watanabe Shozaburo (1885-1962) to design prints. He studied under Kawase Hasui (1883-1957) and in 1931 Watanabe issued his first productions, studies of traditional village life. These technically competent and often charming images were specifically directed to the export market, but seemed to lack the nostalgic romance that foreign collectors had come to expect from Hasui. Koitsu's sales in the West were disappointing.

\section{Ito Shinsui (1898-1972)}

Born in Tokyo, Shinsui was required by family financial circumstances to leave school and begin work for a printing company at the age of ten. His manifest industry and talents gained him advancement into the design department at the company and like others of his generation who would later achieve prominence, he sought out the famous Kaburagi Kiyokata (1878-1973) as a painting teacher. He gained immediate attention as a painter and in 1916 the print publisher Watanabe Shozaburo (18851962) convinced the young artist to produce print designs. Shinsui's print repertoire featured the traditional female beauties as well as strikingly innovative landscapes. Later he would cede the field of landscapes to his contemporary Kawase Hasui (1883-1957) and focus images of women. His ability to deftly convey a range of psychological nuance in his subjects kept pace with attention to changes in style and the social circumstances of the emerging modern Japanese woman.

\section{Kaburagi Kiyokata (1878-1973)}

Kiyokata was born in Tokyo into the family of a newspaper man during the great ascendancy of daily journalism in Japan. With much of his father's newspaper business conducted at home, Kiyokata was immersed in the complex production process and particularly influ- 
enced by his youthful interaction with newspaper illustrators. Under the instruction of Mizuno Toshikata (1866-1908) he studied historical painting themes and styles and progressed as a much-in - demand illustrator for single volume and serialized novels commonly published in newspapers. In addition from about 1910, Kiyokata increasingly turned his attention to painting in the Nihonga style of modernized traditional themes. His forte was the bijin, or beautiful woman, portrait. And his works in this form are regarded as the quintessence of subtely stylish images of contemporary women of the 1910s and 20s, the period roughly corresponding to the reign of the Taisho emperor (1912-26), noted as a period of rather liberal social experimentation. Kiyokata was a highly influential instructor to Ito Shinsui (1898-1972), Kawase Hasui (1883-1957) and other artists who made significant contributions to $20^{\text {th }}$-century Japanese art.

\section{Kajita Hanko (1870-1917)}

Hanko was born in the Shitaya district of Tokyo. He was the son of a highly regarded metalsmith. His apprenticeship in painting was within the the Maruyama-Shijo tradition with is lyrical, slightly sentimental views of the natural world rendered with an emphasis on wash accented by brief accent lines. Hanko distinguished himself as an illustrator for magazines, newspapers and novels. Hanko had strong collaborative relations with prominent novelists of the day and his illustration work for a Japanese-French publication in 1895 brought him to the attention of European audiences. Excellent examples of his work can found in a number of romantic novels featuring stories of the Russo-Japanese War (1904-05). Hanko's images demonstrate great competence, but appeal to the audience demand for romance and sentimental topics.

\section{Kawanabe Kyosai (1831-89)}

Kyosai was born in Shimosa Province, to the east of Edo, but moved to Edo at an early age. He demonstrated drawing and sketching skill as a very young boy and in a series of apprenticeships in Edo was trained in both the Ukiyo-e styles which typically offered depiction of the worlds of theater and brothel and the academic style of the ubiquitous and dominant Kano family school of painting. At the age of 27 he became an independent painter, aligned with no particular school, an increasingly common phenomenon in $19^{\text {th }}$ century Japan. Kyosai was a thorough and knowledgeable researcher of medieval Japanese paintings, particularly the ingeniously animated horizontal narrative hand-scrolls. These works became a source of great inspiration to him. With Japan's opening to world commerce from the 1850s forward, Kyosai's work, both prints and paintings, received considerable exposure at international European exhibitions. His art was often sardonic and darkly humorous. Significantly, he befriended the English architect Josiah Condor (1852-1920), who was hired by the Japanese government to design over fifty Westernstyle buildings for the growing city of Tokyo. Condor's enthusiasm gave Kyosai a strong European, particularly British, following.

\section{Kawase Hasui (1883-1957)}

Hasui was perhaps the best-known and most prolific of the print designers who formed the nucleus of the Shin-hanga (new print) movement under direction of the publisher Watanabe Shozaburo (1885-1962). A Tokyo native, Hasui trained in both Japanese and Western style painting, most notably under Kaburagi Kiyokata (1878-1973). In 1917, inspired by the print designs of his contemporary, Ito Shinsui (1898-1972), Hasui approached Watanabe about the possibility of collaboration. The result was a remarkable, only briefly interrupted partnership that produced more than 600 full-sized prints. Hasui favoured the depiction of landscape and traveled widely in Japan seeking out subject matter. His prints evoked nostalgic, romantic visions of a Japan that struggled to balance traditional and modern values. A keen observer of atmosphere, Hasui constantly refined his techniques of rendering rain, mist, snow and varying light conditions. Hasui's Tokyo residence was destroyed twice, once during the Great Kanto Earthquake in 1923 and again in World War II under Allied bombing. Undeterred, Hasui was resilient and his optimism is reflected in most of his work.

\section{Kobayashi Kiyochika (1849-1915)}

Born in Edo (present-day Tokyo) to a low-ranking samurai, Kiyochika was one of many talented young men who came of age precisely a moment of huge social upheaval in Japan during which the samurai class and its privileges were eliminated. Showing a talent in painting, Kiyochika studied with Charles Wigram (1832-1891), Far-East correspondent and illustrator for the London Illustrated News and with Shimooka Renjo (18231914) one of Japan's first professional photographers. His multifaceted talents were displayed in painting, political cartoon and print design. Kiyochika's lasting contribution was his ability to depict night atmospheres as they were newly defined by man-made light.

\section{Kobayakawa Kiyoshi (1896-1948)}

Kobayakawa was born in Hakata on Japan's western most major island of Kyushu. He eventually apprenticed under Kaburagi Kiyokata (18781973) and became a painter of some distinction in the Nihonga style of modernized visions of traditional taste. In the 1920s he began to design woodblock prints, working with various publishers and concentrated on themes of the appearance of modern Japanese women. He relied little on traditional images, but rather portrayed women as boldly asserting themselves in society. A relatively modest total of thirteen prints are attributed to him.

\section{Natori Shunsen (1886-1960)}

Shunsen was born to a silk merchant in Yamashina prefecture, just to the west of Tokyo. In his early youth, the family moved to Tokyo where Shunsen studied under the painter Kubota Beisan (1852-1906). In 1909 began a career for the literary supplements of a major news- 
paper Asahi. The position brought him into close contact with the noted novelist, Natsume Soskei (1867-1917). His work with Soskei and other prominent novelists lead to a life-long interest in the illustration of literature, and by extension, literature adapted to theatre. In 1916 he exhibited an actor painting that attracted wide attention and the invitation to collaboration with the print publisher Watanabe Shozaburo (1885-1962). The ensuing relationship led to the production of a substantial number of highly acclaimed prints. Shunsen's international reputation was solidified in the 1930s with exhibitions in the United States and at the Warsaw International Print Exhibition. Shunsen continued to be promoted by Watanabe well into the 1950s. The artist was devastated by the untimely death of his twenty-two year old daughter in 1958. Two years later, in a manner reminiscent of the tragedies he illustrated, Shunsen and his wife entered into a double suicide at their family grave.

\section{Negoro Raizan (1887-?)}

Biographical information on Raizen is extremely limited. Documents in Robert Muller's archives indicate that Raizen was a Tokyo resident and that the bulk of his known prints were produced by the publisher Yoshikawa Kobunkan in 1922. Of these, Muller himself acquired eighteen. Most are nocturnes featuring notable architectural sites in Tokyo and Osaka. Raizan's singular achievement is his print, Night at Shinagawa, a stunningly modern rendering of moonlight shimmering on Tokyo Bay at the southern border of the city of Tokyo. Raizen's technique enlists premodern design patterns and the modern viewer's growing awareness of photography to produce a work that is at once abstract but almost legible as a gelatine print photograph. The work is unique.

\section{Ogata Gekko (1859-1920)}

Gekko was born in the Kyobashi district of Edo. His father was a lantern maker. Gekko had no formal training in art, but evidenced talent as a designer of promotional leaflets for book sellers. In the 1880 s he emerged as an illustrator for magazines, newspapers and a designer for book frontispieces. He distinguished himself as a designer of prints depicting battle scenes of the Sino-Japanese War (1894-95), Gekko was in the circle of Japanese artists formed around the American scholarcollector Ernest Fenollosa (1853-1908) and the Japanese art impresario Okakura Kakuzo (1862-1913). Their theoretical and practical commitment was to a revival and renewal of a tradition-based lapanese art that incorporated a sense of the modern and could appeal to an international art market. Gekko's work was advocated by Fenollosa and was exhibited at the St. Louis Exhibition in 1904. In works ranging from nature studies to beauties, Gekko revealed a delicate, sometimes humorous touch. Wash with light line highlights imitated a painting style that relied less on the bold, defining outlines of traditional woodblock prints.

\section{Ohara Koson (1877-1945)}

Born in the city of Kanazawa on the Japan Sea to the north of Kyoto, Koson was a student of the painter Suzuki Kason (1860-1919), himself an eclectic master of several prominent painting styles. He was a noted artist of bird-and-flower subjects. Koson was employed as an illustrator and print designer as well as a painter. His early woodblock print achievements were of scenes from the Russo-Japanese War (1904-05). The American scholar-connoisseur of Japanese art Ernest Fenollosa (1853-1908) was a Koson advocate and recommended his bird and flower paintings to American collectors. It was as a print designer of bird and flower subjects that Koson established his reputation. These prints date approximately from 1911 forward. Koson worked for several publishers and in 1926 changed his name to Shoson when he entered the stable of the publisher Watanabe Shozaburo (1885-1962). Koson's works are undated and distinguished chronologically through the use of sales catalogues and some evidence of stylistic development. His production was almost exclusively for the export market.

\section{Taguchi Beisaku (1864-1903)}

Beisaku was a student of Kobayashi Kiyochika (1849-1915) and is distinguished mainly for powerful woodblock print images featuring scenes of the Sino-Japanese War (1894-95). In these largely successful and popular compositions, he displays his teacher's penchant for dramatic light renderings and contrasts of black and white.

\section{Takahashi Shotei (1871-1945)}

Tokyo born Shotei studied painting with Matsumoto Fuko (1840-1923) and was later hired to work in the foreign affairs section of the Imperial Household. He began a close collaboration with the publisher Watanabe Shozaburo (1885-1962) in 1907. Shotei's works for Watanabe numbered in the hundreds and were produced expressly for the export market. After 1922 he began to use the name Hiroaki. Shotei's print designs contain multiple evocations of key elements found in famous pre-modern prints. All are highly romanticized visions of what Western audiences had come to expect of scenes from a still exotically considered Japan.

\section{Takeuchi Seiho (1864-1942)}

Born the son of a Kyoto restauranteur, Seiho demonstrated prodigy as a student of the distinguished teacher Kono Barei (1844-95). Seiho is the greatest $20^{\text {th }}$ century proponent of a style of painting developed in Kyoto from the last-quarter of the $18^{\text {th }}$ century. The style, named MaruyamaShijo, after Maruyama Okyo (1733-95) and the locale in the city in which he maintained his studio, was characterized by a lyrical, almost gossamer representation of the natural world. The style flourished in Kyoto, supposedly reflective of softer, more delicate approach to visual culture as contrasted with the hard, crisp features of Edo (Tokyo) style. Seiho was not a print maker or designer, but the sheer popularity of his paintings 
created a market for their reproduction in print form. The substantial use of wash in the images was a challenge to the printmaker's art.

\section{Tobari Kogan (1882-1927)}

Kogan, born in the Nihonbashi district of Tokyo, was first employed as an office boy for the Bank of Japan, enhancing his skills by taking night courses in English. An English instructor encouraged him to travel to America. He journeyed to New York in 1901 and enrolled at the Art Student's League. He studied illustration, oil painting and generally immersed himself in the history of Western art. Upon return to Japan in 1906 he became known as illustrator in the Western style. He was a primary theorist and practitioner in print movement philosophically at odds with the Shin-hanga (new print) movement. The Sosaku-hanga (creative print) movement emulated European notions of the artist being in complete creative control of all stages of the print process. This varied from the Shing-hanga approach which employed the traditional guild system of designer, block cutter and printer. To this end, in 1922 Kogan published a book of step-bystep instructions in print making. His prints generally possess strong line and bold design qualities perhaps necessitated by the limitations of a one person production process. Curiously, but true to his eclectic interests, Kogan went on to distinguish himself primarily as a sculptor.

\section{Torii Kotondo (1900-76)}

Kotondo was born in the Nihonbashi district of Tokyo. He received a varied but substantional training several of the traditional Japanese painting styles, but at the comparatively early age of fifteen was adopted into the Torii family of print makers by the seventh generation head of that lineage. The Torii family had specialized in actor and theatrical prints from the $18^{\text {th }}$ century and young Kotondo was trained in the classical forms made so prominent by his adoptive family. The Torii family was nevertheless engaged in the brisk competition to modernize and Kotondo produced, for example, advertising posters for Kabuki plays. He was able to branch into illustration for magazines and newspapers and in 1917 came under the tutelage of Kaburagi Kiyokata (1878-1973), a seminal instructor for many talented $20^{\text {th }}$ century painters and print designers. It was from this time that he developed a strong interest in the female beauty print. In 1929 he succeeded his adoptive father and became the head of the Torii line.

\section{Toyohara Kunichika (1835-1900)}

Kunichika was born in Edo and studied under the print masters including Utagawa Kunisada (1786-1864). Kunichika's work represented the final stages of the traditional Ukiyo-e (floating world) woodblock print form in both subject and style. His works attempted accommodation to modern tastes and relied on highly dramatic, sometimes macabre presentations. His technical innovations with the triptych format did bring increased power to images and he was known for especially interesting and provocative actor portraits. Much of scholarship through the mid- $20^{\text {th }}$ century viewed his work as an example of the "decandent" decline of the traditional genre, but more recent critical appraisal has recognized the appeal of his work.

\section{Tsuji Kako (1870-1931)}

Kako was a much revered Kyoto painter who was born into a family of textile designers and dyers. Many of his works reflect a powerful use of repetitive design patterns and his mastery of water forms, especially in his woodblock print designs has often been commented upon. As well, Kako was known as a serious practitioner of Zen Buddhism and many sought his advice on spiritual matters.

\section{Tsukioka Yoshitoshi (1839-92)}

A resident of Edo, Yoshitoshi is generally regarded as the last great transitional artist of $19^{\text {th }}$ century Japan. Trained in the styles of Ukiyo-e, the genre of the pleasure quarters of theatre and brothel under Utagawa Kuniyoshi (1797-1861) and in traditional historical theme painting under Kikuchi Yosai (1788-1878), Yoshitoshi's early prints in the traditional style, particularly of legendary warrior heroes, revealed competence and some hints of a future hyper-dramatic style. Yoshitoshi was eclectic in his production. The battle actions in the civil war fought between Tokugawa shogunal forces and troops pressing for an imperial restoration in the 1850 s and 60 s were depicted by Yoshitoshi with distinctive verve. From the late 1860 s he, like many contemporaries, supplied newspapers with illustrations and broadsheet prints to advertise Kabuki plays. It was from this time that his themes dwelt on history, legend and fable. His style and format favoured dramatic, innovative compositions and showed the influence of Western-style modelling and foreshortening in figural representation. His overall tone was macabre, haunting and occasionally depressive, perhaps reflecting a deteriorating mental state.

\section{Uehara Konen (1878-1940)}

The limited biographical information available on Konen indicates that he studied under Kajita Hanko (1870-1917) and Matsumoto Fuko (1840-1923). He produced prints for the Tokyo publisher/dealer Kobayashi Bunshichi (1864-1923). Most of these prints were reproductions of popular pre-modern prints or works obviously derevative of them. Kobayashi catered to an export market. In the 1920s Konen displayed increased originality and maturity. His best works of that period played on the theme of nocturne, a subject of consistent interest to Shin-hanga movement designers.

\section{Watanabe Seitei (1851-1918)}

Trained in Japanese classical painting techniques with the noted artist Kikuchi Yosai (1788-1878), Seitei benefited from Japan's opening to the 
West in the mid- $19^{\text {th }}$ century and became an adept designer for ceramic and textile patterns and other industrial projects. His work received national exposure at domestic trade fairs and international acclaim for a painting entered into the Paris Exhibition in 1878. He briefly studied Western-style painting in Paris. Upon return to Japan, while not giving up painting, he focused his attention on the design of woodblock prints and bookplates. His work is characterized by sharp, precise and intimate designs.

\section{Yamamura Koka (1885-1942)}

Born in the Shinagawa area of Tokyo, Koka had initial training under Ogata Gekko (1859-1920) and later enrolled in the Tokyo Fine Art School from which he graduated in 1907. His attraction to the actor print genre is dated to productions in 1915 and a year later he entered into a longstanding collaboration with the publisher Watanabe Shozaburo. Kabuki was a highly populist theatrical form that emerged in the early 1600's, first in Kyoto and rapidly finding favour in Osaka and Edo. Styles of performance varied with region as did a natural genesis of complexity and sophistication. During the late $19^{\text {th }}$ and early $20^{\text {th }}$ century, Kabuki underwent a series of reforms directed at promoting the genre as a type of national art form that could represent Japan to the world. Images of actors, indeed the whole theater type, were in competition with film and other forms of stage performance. Koka and others, produced bold dramatic portraits which, although referent to traditional actor images, used more Western-style modelling and sought to present the actual facial characteristics of the actor rather than the overlay of caricature which was typical of pre-modern works.
Yoshida Hiroshi (1876-1950)

Yoshida Hiroshi's popularity and prominence in Western collections possibly surpasses that of Kawase Hasui (1883-1957). Born in Fukuoka, in western Japan, Yoshida studied Western-style painting in Kyoto and in Tokyo. He was particularly interested in the impressionistic effects achieveable with oil painting. Between 1899 and 1925 he made three trips to North America and two to Europe. As well, he travelled to China, Southeast and South Asia. Thus his repertoire of subjects was notably international - cityscapes of New York, Pittsburgh, scenes of the Canadian Rocky Mountains, the Taj Mahal, and teeming marketplaces of Malaysia. Yoshida's forte was in producing woodblock prints that captured the sense of oil painting; joined masses of color rather than line tended to define his images. And like other early $20^{\text {th }}$-century Japanese print designers, Yoshida was a master at the technical rendering of atmosphere and light.

\section{Yoshikawa Kanpo (1894-1979)}

Born in Kyoto, Kanpo studied with Takeuchi Seiho (1864-1942) later enrolling in the Kyoto School of Painting from which he graduated in 1920. The modern revival of the actor print genre within the Shin-hanga (new print) movement was largely a Tokyo based initiative. Kanpo is distinguished by being the first major artist to apply the techniques and perspectives of the more delicate and subtle Kyoto tradition to the new print renderings of actors. Appropriately and compared with the Tokyo style, depiction of obvious emotional expression, either through body gesture or facial expression, is greatly restrained but made apparent by fine compositional tensions including the use of exquisite textile patterns. Kanpo also excelled at the representation of male actors who, in the Kabuki tradition, played female roles. While Kanpo occasionally ventured into landscape studies, his primary genre was the actor portrait. 



\section{Glossary}

bijin

Term referring to beautiful women.

\section{bijinga}

A term referring to the genre of paintings and prints of beautiful women.

\section{bokashi}

A printing technique that achieves tonal gradation by partially wiping pigment off of the print block.

\section{Edo}

The premodern name of present-day Tokyo. The name was changed from Edo to Tokyo in 1868 when Tokyo replaced Kyoto as the national capital.

\section{fükeiga}

A term referring to the genre of landscape paintings and prints. Fükeiga woodblock prints enjoyed marked popularity from the beginning of the $19^{\text {th }}$ century.

\section{hanshita-e}

A preparatory drawing in black ink on thin paper. This drawing provided the woodblock carver with a template which he pasted on the smooth block surface and used as a carving outline. By definition, hanshita-e are destroyed in the carving process. Some survive because publishers decided not to follow through with production of the image.

\section{Kabuki}

A traditional form of Japanese theater that developed from informal, ribald skits in the early $17^{\text {th }}$ century into sophisticated and visually gorgeous productions over the following two centuries. Representations of famous plays and actors was a mainstay genre of the woodblock print publisher.

\section{kachöga}

The term refers to the visual representation of flowers and birds in both painting and woodblock prints. Kachōga enjoyed particularly popularity as a woodblock print subject in the $19^{\text {th }}$ century.

\section{Kano}

A family name that came to define the dominant school of painting style during the Edo period (1600-1868). At its best, the Kano style was a successful blend of Chinese Ming painting with the softening effect of traditional Japanese court-style painting. The Kano family of ateliers served as official painters to the shogun (the military and defacto ruler of Japan). Established as the academy style from around 1600 until the mid-19 $19^{\text {th }}$ century, this was the style initially mastered by many of the early $20^{\text {th }}$ century print designers.

\section{kuchi-e}

Literally "mouth picture". This term defined the multicolored tipped-in frontispieces in books produced in the late- $19^{\text {th }}$ and early $20^{\text {th }}$ century.

\section{Maruyama-Shijó}

A style type attributed to the Kyoto painter Maruyama Okyo (1733-95). The artist's atelier was on Shijo street. The style is characterized as a lyric realism, combining sharply rendered observations of nature within a generally soft, impressionistic context.

\section{Nanga}

Literally "southern painting". This style of painting developed in Japan as an emulation of Chinese amateur scholar-painter paintings of the Ming and Ching dynasties. It was loosely applied, but was a stylistic identification sought by Japanese painters who had a strong affinity with Chinese culture as it was presented to Japan from the $17^{\text {th }}$ century forward. Some prominent late $19^{\text {th }}$-century print designers were practitioners of this style.

\section{Nihonga}

Literally "Japanese painting". This was a painting style that developed from the late $19^{\text {th }}$ century as a search for an effective "modern" idiom for traditional Japanese themes.

\section{onnagata}

Literally "in the form of a woman". This term applied to male Kabuki actors who performed in female roles. With rare exceptions, all performers on the Kabuki stage have been men. 


\section{Rinpa}

Sometimes rendered as Rinpa, this style of painting developed in the early $17^{\text {th }}$ century and was the result of efforts by professional painters in the urban areas of Kyoto and Edo to add new interpretive vigor to moribund styles of professional court painters. The urban painters essentially usurped themes previously the exclusive purvue of court painters. The style is decorative, delicate and occasionally includes sumptuous use of gold and silver. Some print designers of the late $19^{\text {th }}$ and early $20^{\text {th }}$ century brought the Rinpa sensibility to the woodblock print.

\section{Shin-hanga}

Literally "new print(s)". This movement was consciously initiated by the publisher Watanabe Shōzaburō (1885-1962) as an attempt to stimulate a contemporary market for guild-produced woodblock prints. Watanabe employed young, talented painters as designers and encouraged them to produce modern interpretations of traditional print themes. Watanabe sought to raise the woodblock print to the status of fine art, a notion resisted by many Japanese historians and connoisseurs who thought the woodblock print to be plebian.

\section{Sösaku-hanga}

Literally "creative print(s)". This is a style of print making inspired by late$19^{\text {th }}$ century Japanese exposure to the Western artists who created prints - from design, through block-cutting to impressions - solely by their own hands. This notion ran counter to the Japanese method of guild production that employed the "artist" only as a designer and relied on professional block cutters and printers as an integral part of the project. Advocates of the Sōsaku-hanga method under stood the style as a means of asserting totally artistic control over a project.

\section{Ukiyo-e}

Literally "pictures of the floating world". In ancient times the "floating world" (ukiyo) referred to the fleeting, ephemeral material world, the source of pain and unrequited desire. Later, with the rise legalized pleasure quarters in the major Japanese cities, the "floating world" came to denote the escapist pleasure of theater and brothel. Images of the demimonde came to be known as Ukiyo-e. In time Japanese woodblock prints, regardless of theme, took on the generic identity of Ukiyo-e.

\section{yakusha-e}

Literally "pictures of actors". Woodblock prints featuring actors, in single portrait or shown within stage scenes, were the earliest form of Ukiyo-e, produced from the early $17^{\text {th }}$ century. 


\section{Bibliography}

\section{GENERAL}

Conant, Ellen et al. Nihonga: Transcending the Past. St. Louis: St. Louis Art Museum, 1995

Forrer, Matthis (ed.). Essays on Japanese Art Presented to Jack Hillier. London: Robert G. Sawers Publishing, 1982

Lane, Richard. Images of the Floating World: The Japanese Print. Fribourg: Office du Livre, 1978

Leiter, Samuel L. New Kabuki Encyclopedia: A Revised Adaptation of Kabuki jiten. Westport and London: Greenwood Press, 1997

Newland, Amy (ed.). The Commercial and Cultural Climate of Japanese Print Making. Amsterdam: Hotei Publishing, 2004

\section{SELECT}

Brown, Kendall H. et al. Light in Darkness: Women in Japanese Prints of Early Showa (1926-1945). Los Angeles: Fisher Gallery, University of Southern California, 1996

Brown, Kendall H., and Hollis Goodall-Cristante. Shin-hanga: New Prints in Modern Japan. Los Angeles: Los Angeles County Museum of Art in conjunction with the University of Washington Press, Seattle, 1996

Brown, Kendall H., and Sharon A. Minichiello. Taisho Chic: Japanese Modernity, Nostalgia and Deco. Honolulu: Honolulu Academy of Arts, 2002

Brown, Kendall H. et al. Kawase Hasui: The Complete Woodblock Prints. Amsterdam: Hotei Publishing, 2003

Hamanaka, Shinji, and Amy Reigle Newland. The Female Image: $20^{\text {th }}$ Century Prints of Japanese Beauties. Tokyo: Abe Publishing and Leiden: Hotei Publishing, 2000

Jenkins, Donald. Images of a Changing World: Japanese Prints of the Twentieth Century. Portland: Portland Art Museum, 1983

Machida City Museum of International Graphic Art [Machida Shiritsu Kokusai Hanga Bijutsukan] (ed.). Taisho jojo - Shin-hanga no bitten: Watanabe Shozaburo to Shin-hanga undo (Taisho Lyricism: Exhibi- tion of the Art of Shin-hanga. Watanabe Shozaburo and the Shinhanga Movement). Tokyo: Machida City Museum of International Graphic Art, 1989

Merritt, Helen. Modern Japanese Prints, The Early Years. Honolulu: University of Hawaii Press, 1990

Merritt, Helen, and Nanako Yamada. Guide to Modern Japanese Woodblock Prints 1900-1975. Honolulu: University of Hawaii Press, 1992

Merritt, Helen, and Nanako Yamada. Woodblock Kuchi-e Prints. Reflections of Meiji Culture. Honolulu: University of Hawaii Press, 2001

Minneapolis Institute of Arts (ed.). A Japanese Legacy: Four Generations of Yoshida Family Artists. Minneapolis: Art Media Resources, 2002

Mirviss, Joan B. "A Tribute to Robert O. Muller (1911-2003)." Impressions, The Journal of the Ukiyo-e Society of America, Inc. 25 (2003), 109-15

Mirviss, Joan B., and James Ulak. "Robert O. Muller (1911-2003)." Orientations, vol. 34, no. 7 (September 2003), 85-87

Newland, Amy et al. Crows, Cranes and Camellias. The Natural World of Ohara Koson. Leiden: Hotei Publishing, 2001

Newland, Amy (ed.). Printed to Perfection: Twentieth-Century Japanese Prints from the Robert O. Muller Collection. Washington: Arthur M. Sackler Gallery, Smithsonian Institution in association with Hotei Publishing, Amsterdam, 2004

Pachter, Irwin, and Kaneko Takushi. Kawase Hasui and His Contemporaries: The Shin-hanga Movement in Landscape Art, Syracuse: Everson Museum of Art, 1986

Smith, Henry D. II. Kiyochika: Artist of Meiji Japan. Santa Barbara: Santa Barbara Museum of Art, 1988

Smith, Lawrence. The Japanese Print Since 1900. Old Dreams and New Visions. New York: Harper and Row, 1983

Smith, Lawrence. Modern Japanese Prints 1912-1989. Woodblocks and Stencils. London: British Museum Press, 1994

Stephens, Amy Reigle (ed.). The New Wave: Twentieth-Century Japanese Prints from the Robert O. Muller Collection. Leiden: Hotei Prints and London: Bamboo Publishing, 1993 



\section{Index}

A

Aesop 93

Akiyama Kii-no-kami (character) 24

Arthur M. Sackler 19

Asakusa 78

B

Benten Pond 69

Benten Shrine 76

bijin (beauty) 58

Biwa Lake 79

Blow, Thomas Bates (collector) 13, 15

bokashi (tonal gradation) 93

\section{C}

Chiossone, Eduardo (engraver) 96

Chōbei (character) 31

chōjü-giga ('frolicking animals') 90

D

Danshichi 32

Doi Sadaichi (publisher) 72, 73

Dötonbori 66,81

\section{E}

Edo $28,31,32,70$

\section{F}

First National Industrial Exhibition (Tokyo, 1877) 84

Freer, Charles Lang 19

Freer and Sackler Galleries 17
Fujiwara no Yasumasa (actor) 37

Fuwa Banzaemon (character) 26

Fuyö (artist) 96

G

gauffrage 54

Giheiji (character) 32

gofun 96

Great Kantō Earthquake (1923) 62, 72, 74

\section{$\mathrm{H}$}

Hakoya Minekichi (character) 22

Hanai Oume 22

Hashiguchi Goyō (artist) 51-55, 57, 68

Hidaka River 45

Hirose River 66

Hitotsuru of Osaka (geisha) 46

Honnoji, temple 30

Honshū 64,66

Hōryūkaku 38

\section{I}

Ibaraki 38

Ichikawa Danjurō IX (actor) 24, 26

Ichikawa Ennosuke (actor) 34

Ichikawa Kigan (Onimaru) V (actor) 35

Ichikawa Sadanji I (actor) 24

Ichikawa Sadanji II (actor) 33

Igami no Gonta (character) 28

Ikaho 65

Ikeda (publisher) 50

Imperial Academy of Fine Arts Exhibition

(1927) 47,62

Inchon Harbour 41

Ishiyama 79

Itö Shinsui (artist) 16, 56-59, 72, 79

\section{J}

Jitsukawa Enjaku II (actor) 28, 32

\section{K}

Kabuki 21, 22, 26, 28, 30, 31, 32, 33, 35, 37, 38, 44

Kaburagi Kiyokata (artist) 47

Kajita Hanko (artist) 44

Kakudayū 34

Kamiya Jihei 28

Kanda district 55

Kanda River 80

Kansai 28

Kawase Hasui (artist) 13, 15, 16, 64, 65, 66, 69, 70, 72, 73, 74, 78

Kataoka Gadō XII (actor) 28

Kawanabe Kyōsai (artist) 15, 84, 86, 92

Kayo of Kyoto (gaisha) 46

Kiyohime 45

Kiyosu (bridge) 74

Kobayakawa Kiyoshi (artist) 48

Kobayashi Bunshichi (publisher) 81

Kobayashi Kiyochika (artist) 13, 15, 46, 61, 65, $75,76,78,84$

Kobe 28

Koharu 28

Kokichi of Tokyo (geisha) 46

Kyoto 21, 28, 30, 38, 46, 79, 86, 93

Kyushu 68

L

Lake Biwa 79 
M

Manchuria $37,38,40$

Matsushima Bay 78

Meiji 13, 15, 26, 28, 33, 38, 76, 93

Merwin's Art Shop 17

Minamoto Yoritomo 24

Mirviss, Joan B. 17, 19

Miyuki 28

modan garu (modern girl) 48

Mongaku Shōnin 24

\section{N}

Nakamura Ganjirō I (actor) 28

Nakamura Kichiemon I (actor) 30

Narukami 33

Natori Shunsen (artist) 14, 30, 31, 32, 33, 34, 35

Negoro Raizan (artist) 75

Neill, Mimi Gardner 17

$\mathrm{O}$

Oda Nobunaga 24, 30

Ogata Gekkō (artist) 86, 91

Ōgoshi Dairoku (writer) 44

Ohara Koson (Shōson) (artist) 83, 87, 89, 90 , 95,97

Ōmi 72,79

onnagata 35

Onoe Kikugorō V (actor) 22

Onoe Matsusuke IV (actor) 22, 31

Osaka $28,46,66,81$

Oshichi 44

otokodate 32

Otomi 35

\section{$\mathbf{P}$}

Paris Exposition Universelle (1878) 88

Pearl Harbour 17

Port Arthur 41

$\mathrm{R}$

Rashōmon bate 38

Robert Lee Gallery 17

Russo-Japanese War (1904-05) 37, 38, 87
S

Sanada Yukimura 26

Sawada Jushichi 38

Second National Industrial Exhibition (Tokyo, 1881) 86

Sendai 66,78

Seoul 41

Shanghai 36,48

Shiba 69, 70

Shiba Park 69

Shima Art Company 16

Shin-hanga ("New Prints") 15, 16, 17, 21, 61, $64,66,75,81,83,85,93$

Shinagawa 75

Shinkawa 72

Shinobazu Pond 76

Shinto 91

Shiobara 64

Sino-Japanese War (1894-95) 37, 38

sōsaku-hanga (Creative Prints) 47

Sumida River 72

Sumii 16

\section{T}

Taguchi Beisaku (artist) 40

Taishö 28

Takahashi Shōtei (Hiroaki) (artist) 48, 80, 85

Takamatsu 30

Takanawa Ushimachi 76

Takechi Mitsuhide 30

Takeda 24

Takeuchi Seihō (artist) 93

Tarö Inari Shrine 78

Tenjiku Tokubei 22

Tobari Kogan (artist) 47

Tokugawa 70

Tokyo $14,15,16,22,28,38,46,47,48,55,69$, $70,72,74,75,76,78,80,81,94$

Tokyo Bay 47

Tokyo School of Fine Arts 51, 53

Tomi (model) 52, 54, 55

Torii Kotondo (artist) 50

Tōyama 34

Toyohara Kunichika (artist) 22, 24, 26, 28

Tsukiji Akashi-chō 47

Tsuji Kakō (artist) 41

Tsukioka Yoshitoshi (artist) 15, 37, 38, 44, 45
U

Uehara Konen (artist) 81

Ueno 94

Ukiyo-e (pictures of the floating world) 17 ,

$24,65,81$

Ulak, Dr. James 17,19

Utamaro (artist) 53

W

Watanabe no Tsuna 38

Watanabe Seitei (artist) 85,88

Watanabe Shōzaburō (publisher) $14,15,16$,

$21,53,56,62,64,65,66,81,94$

$\mathrm{X}$

Xiang 79

Xiao 79

Y

Yabakei Valley 68

Yale 17

Yamamura Kōka (Toyonari) (artist) 36, 48, 94 Yasugi Minekichi 22

Yoshida Hiroshi (artist) 62

Yoshikawa Kanpō (artist) 28

Yoshitsune 24, 28

Z

Zōjōji (Buddhist temple) 70 



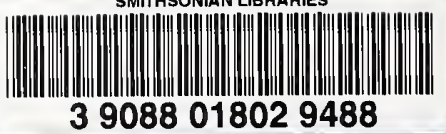

